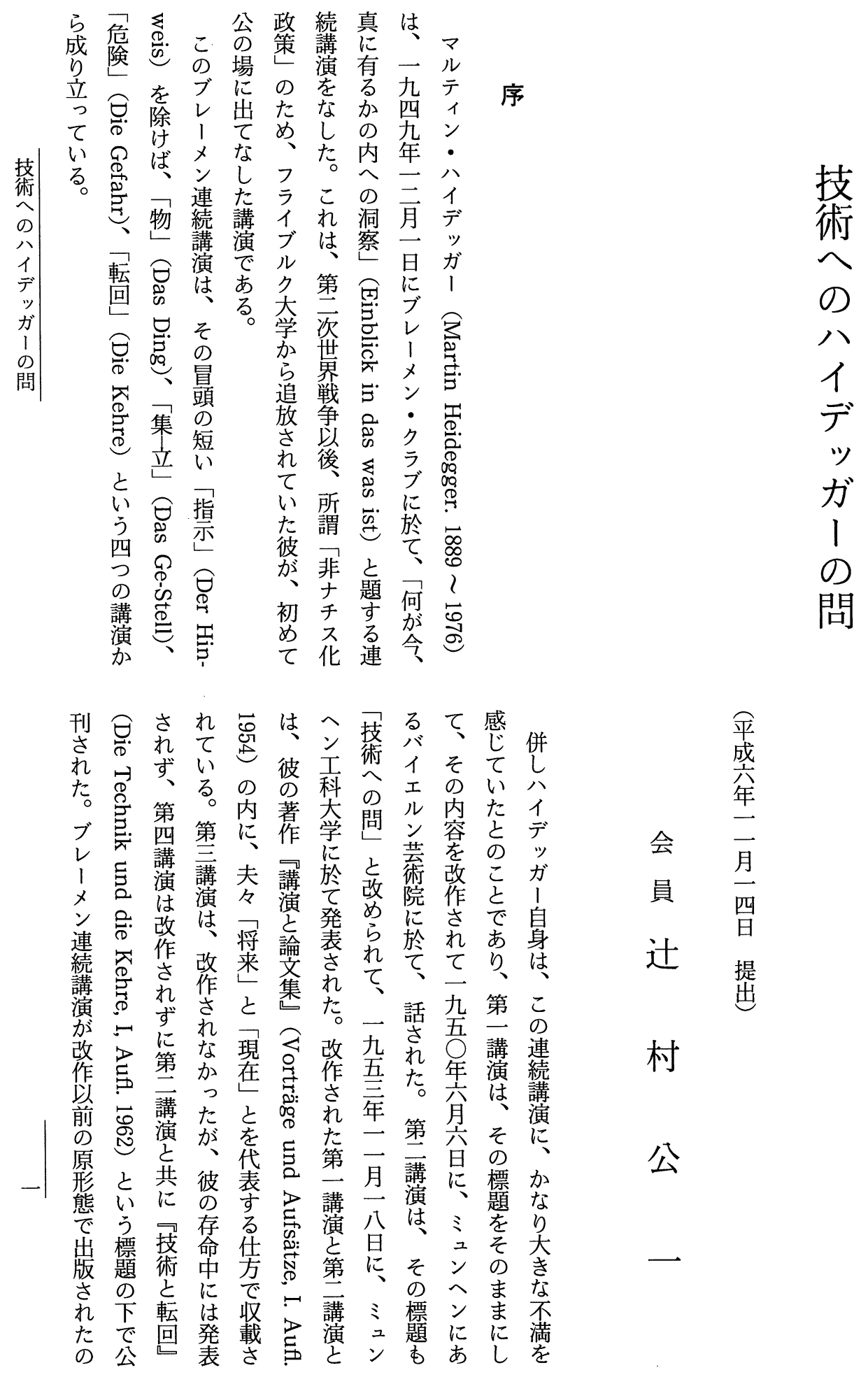




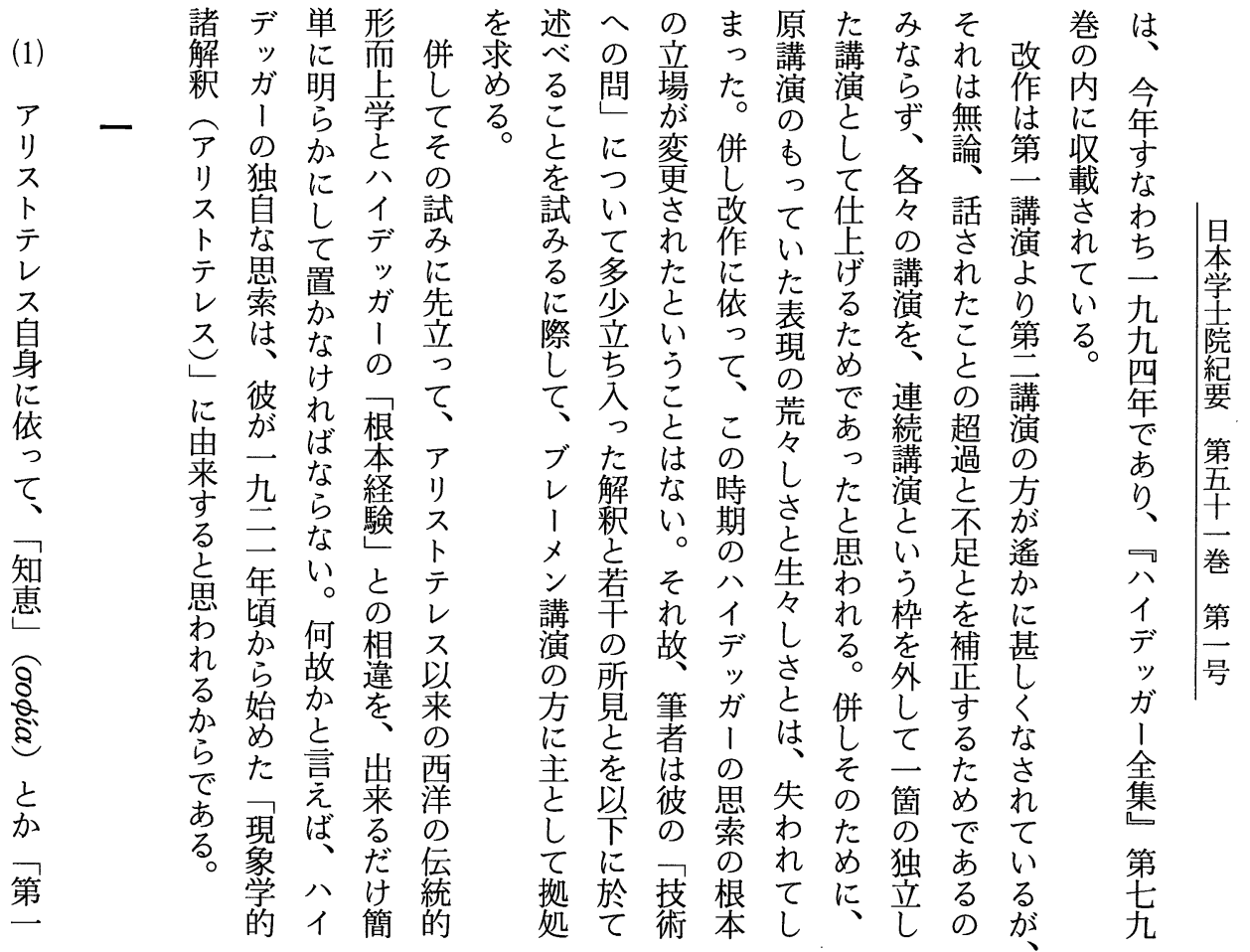

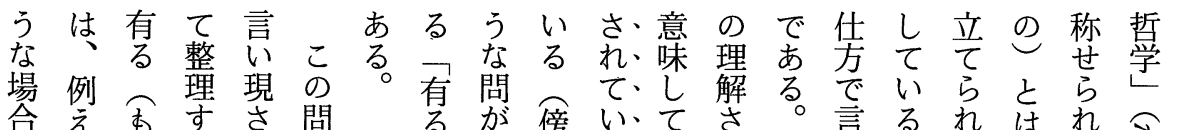

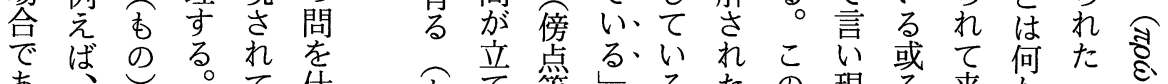

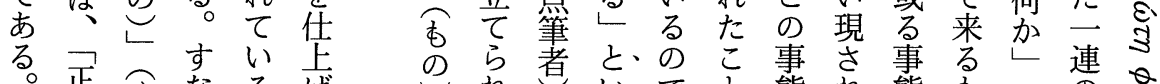

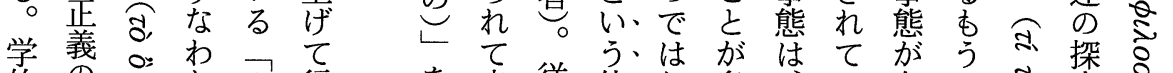

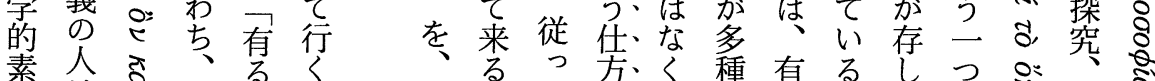

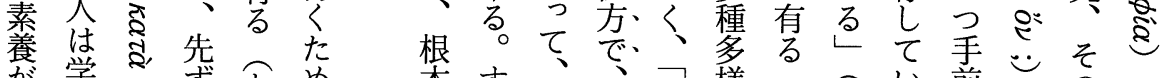

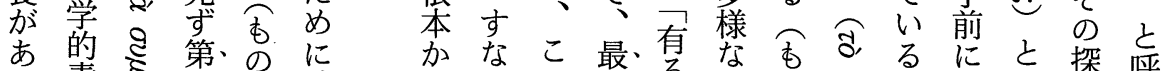

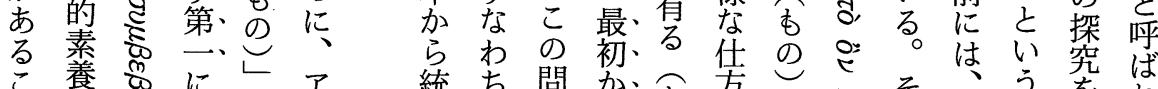
亡 養惫に

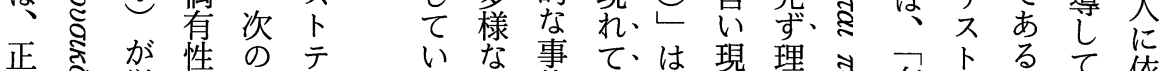

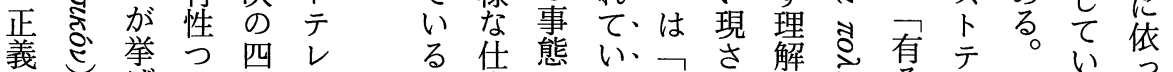

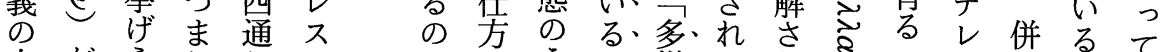

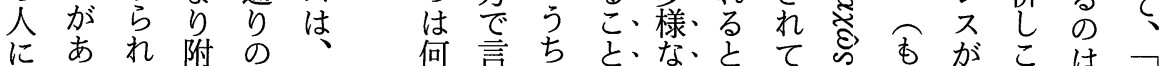

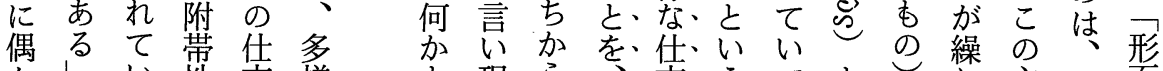

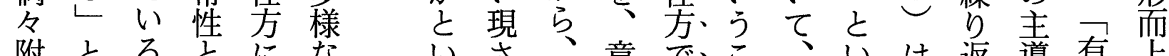

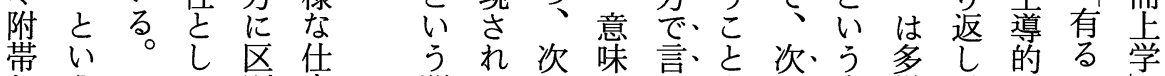

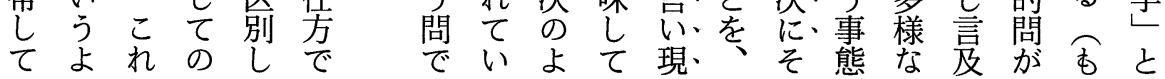




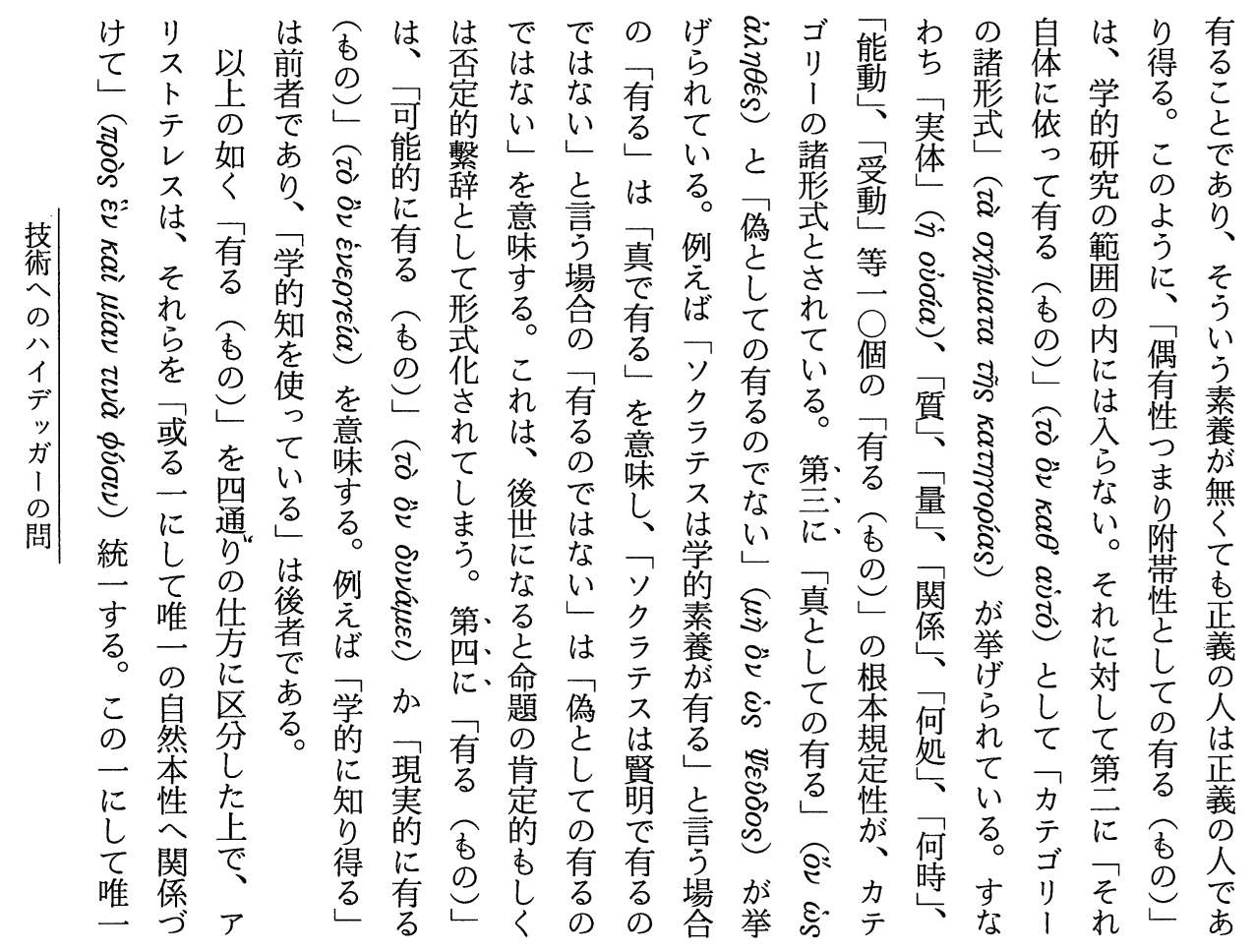

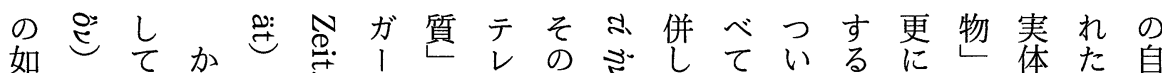

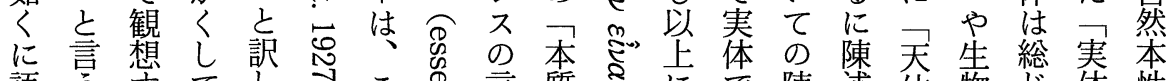

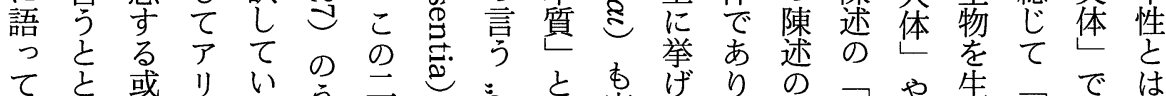

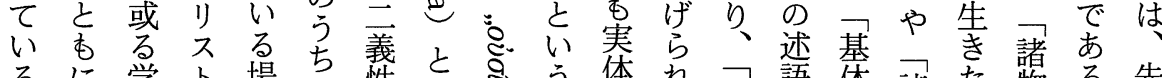

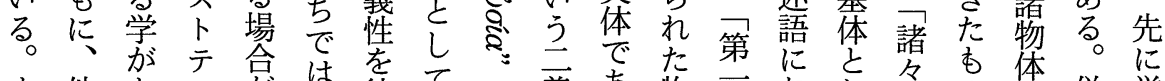

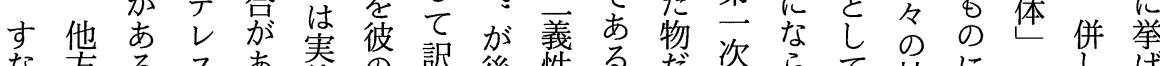

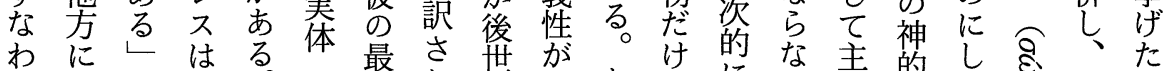

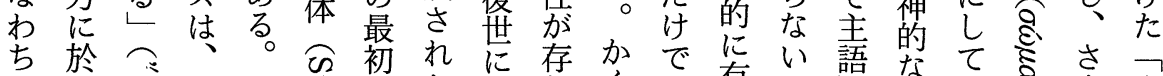

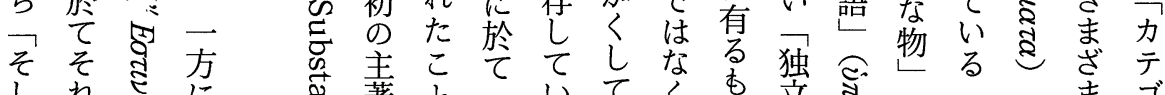

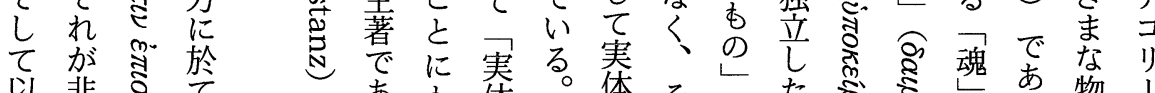

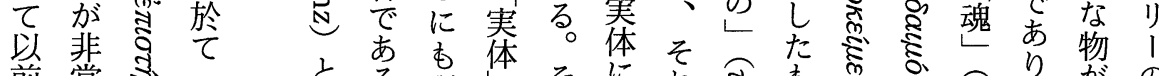

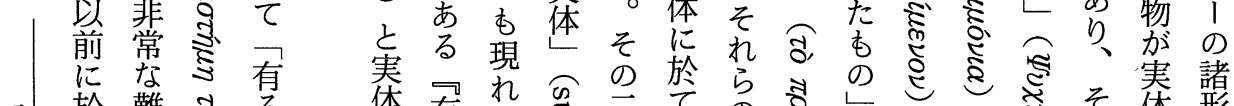

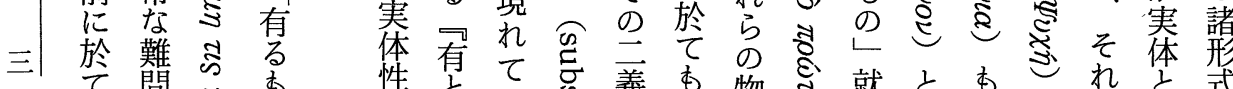

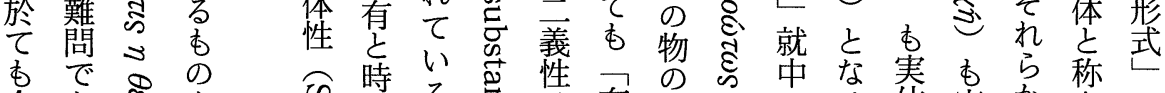

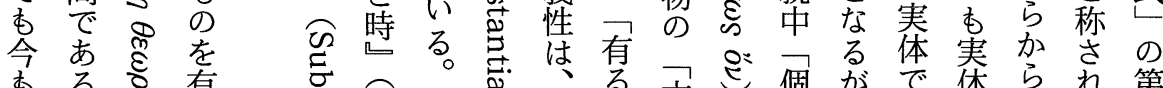

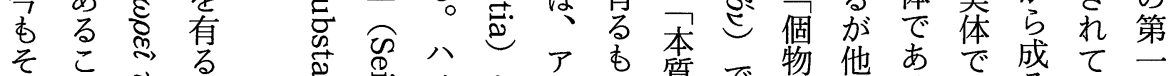

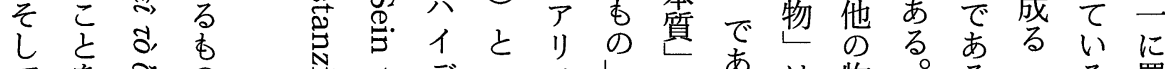

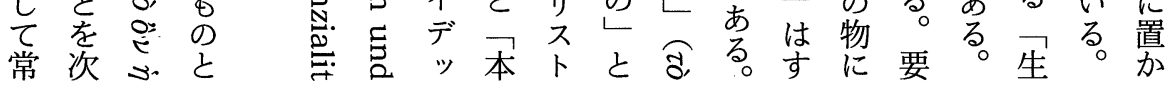




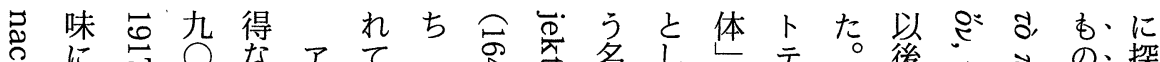

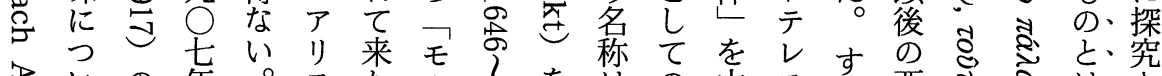

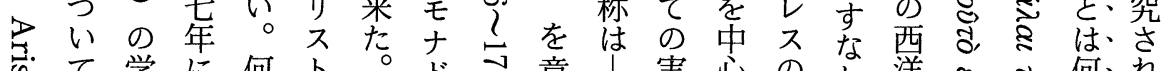

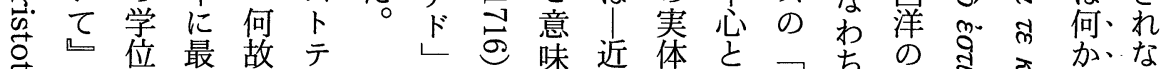

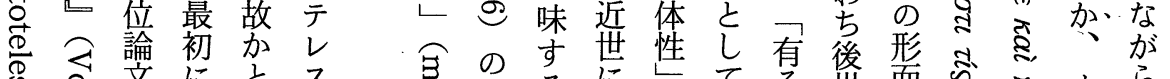

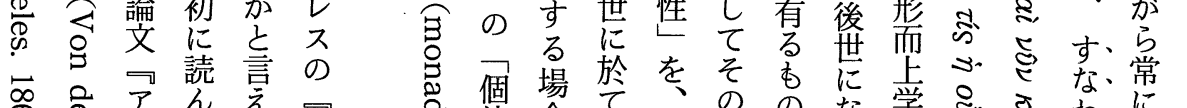

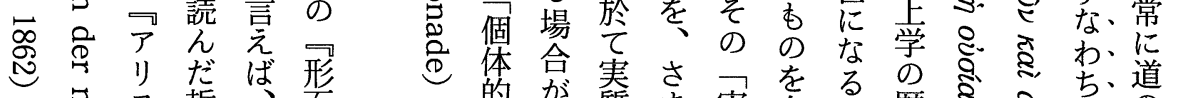

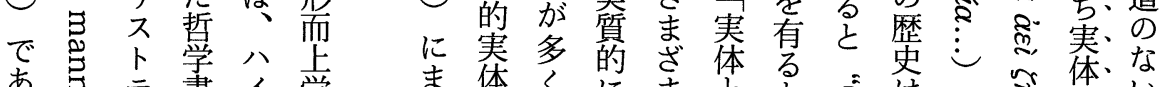

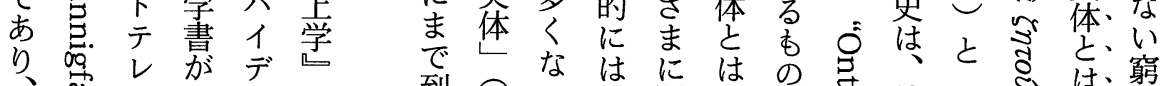

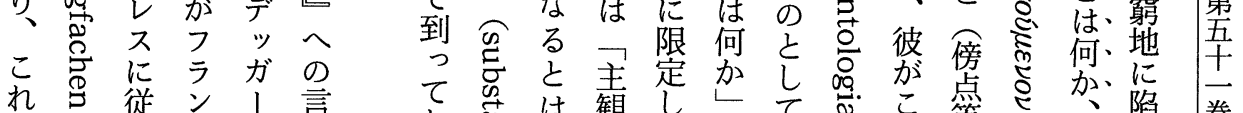

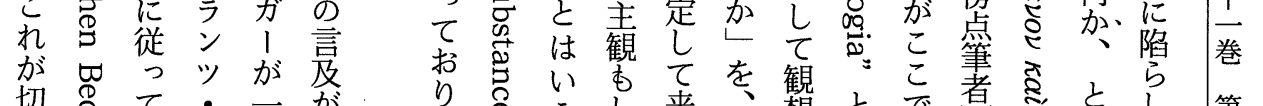

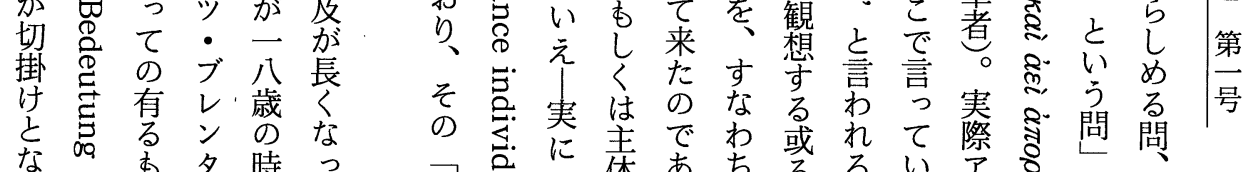

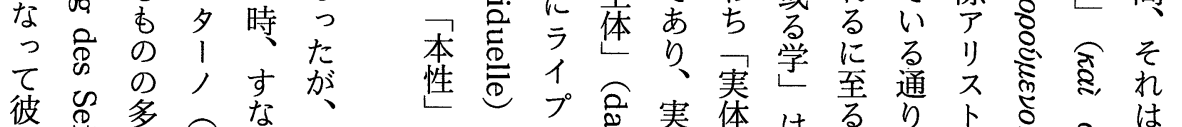

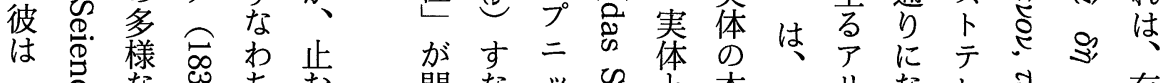

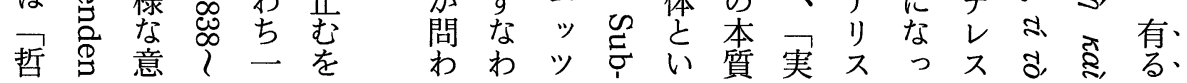

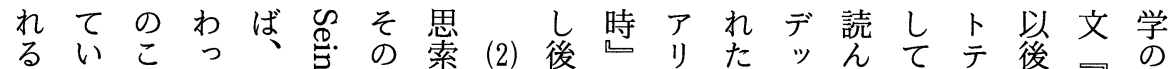

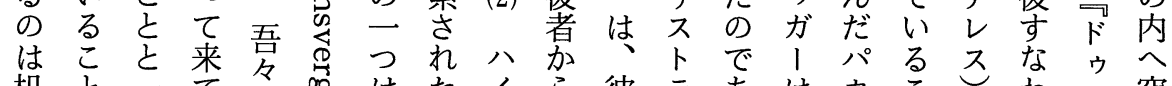

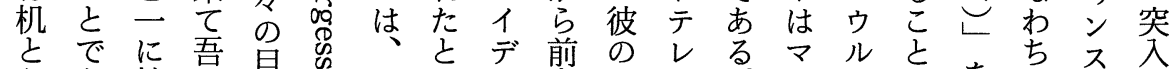

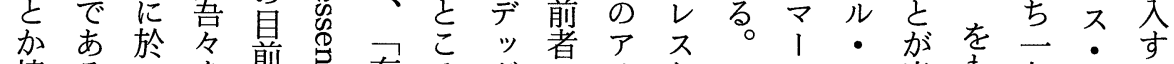

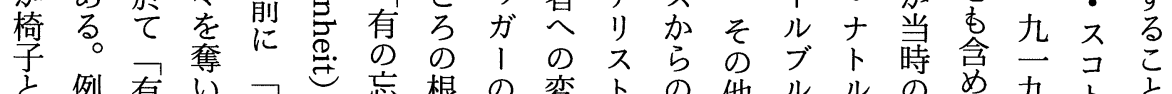

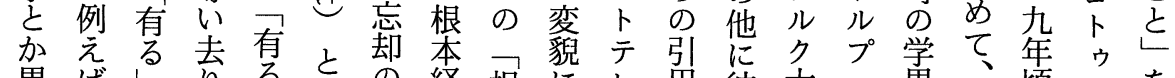

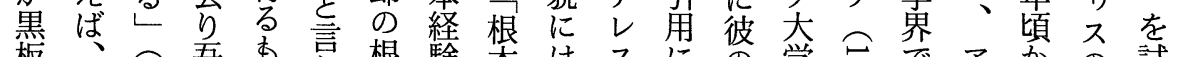

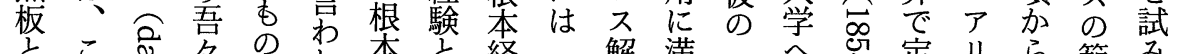

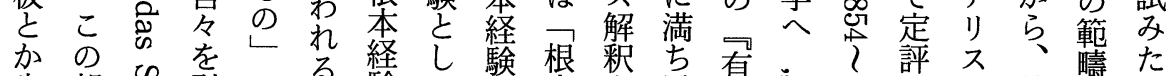

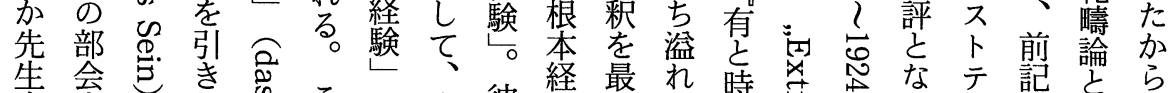

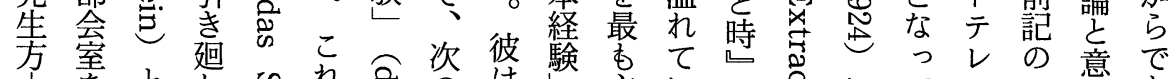

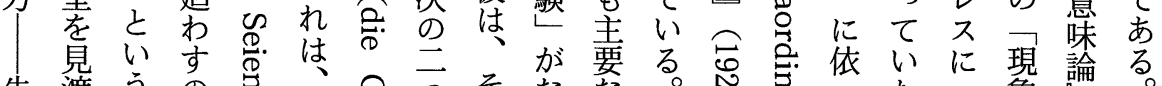

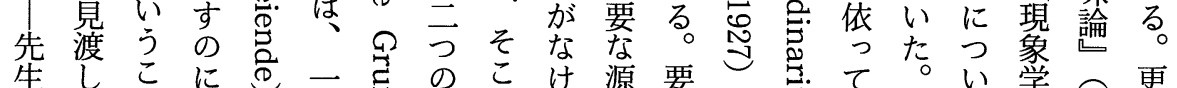

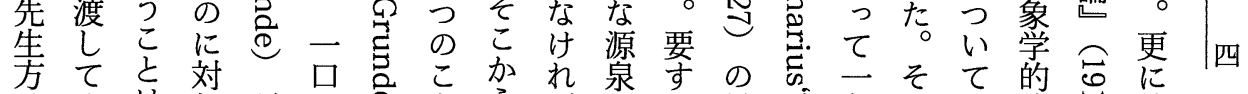

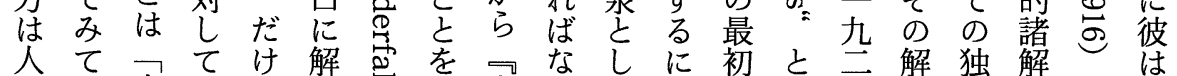

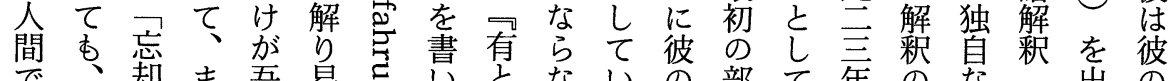

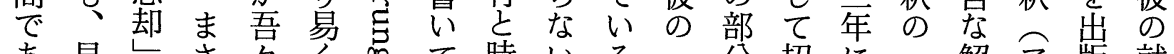
あ見さ多品て時いる。分招に解予版就

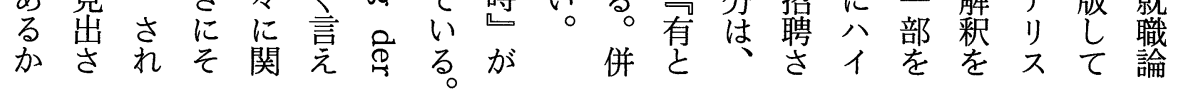




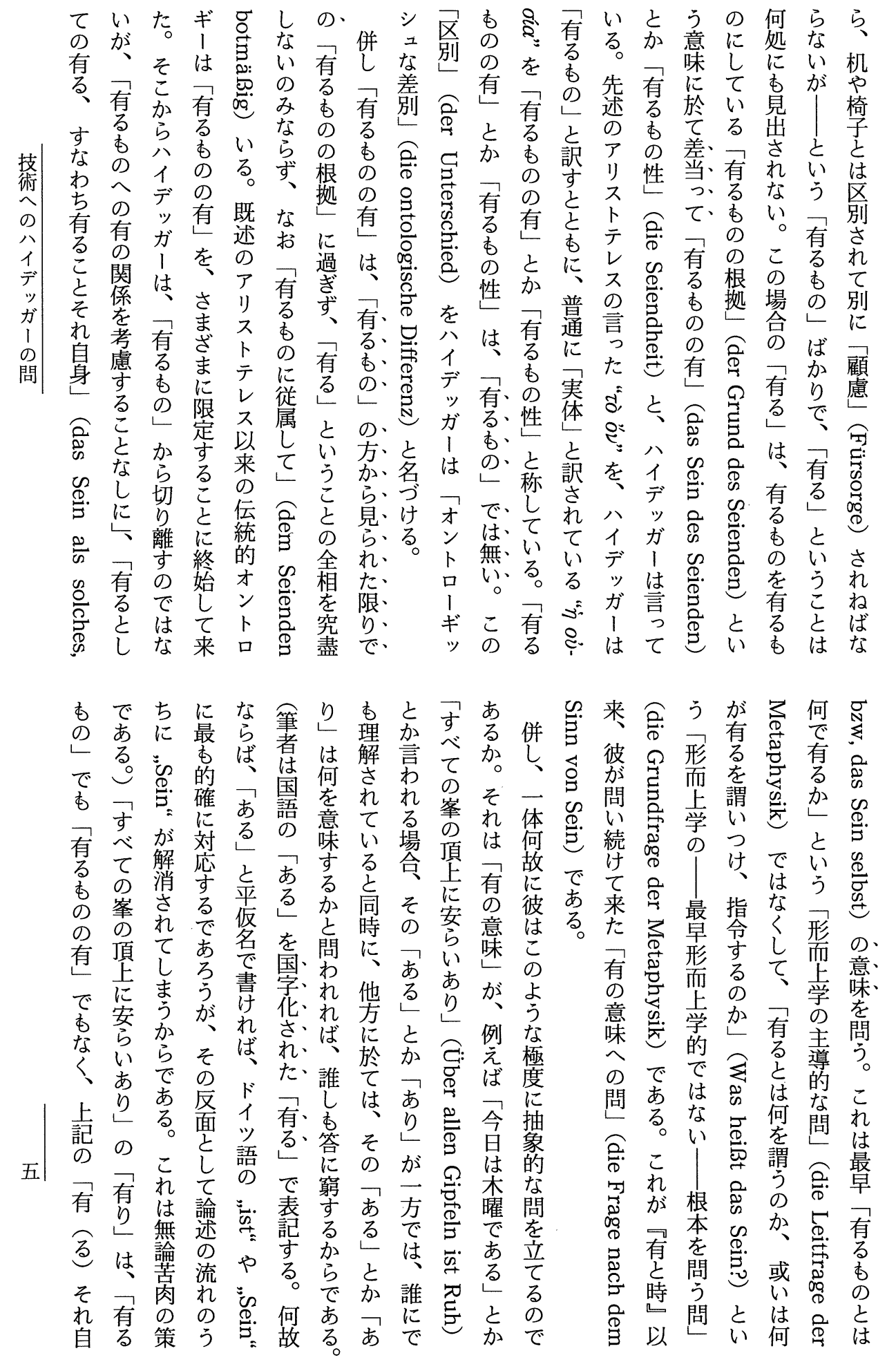




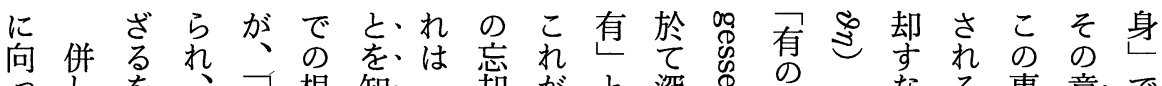

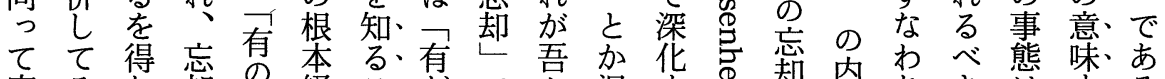

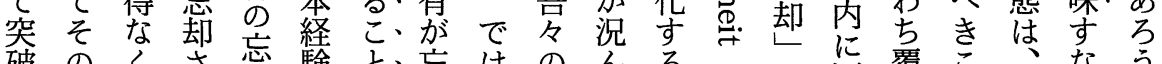

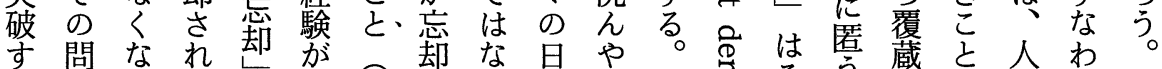

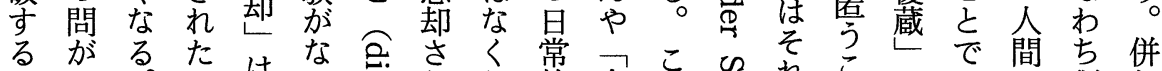

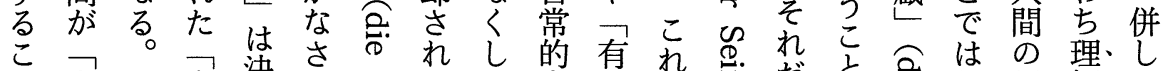

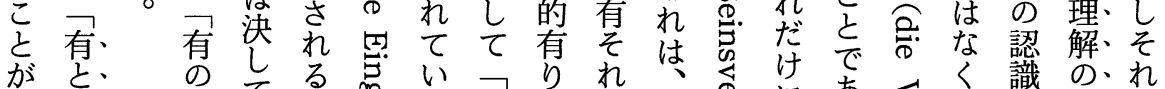

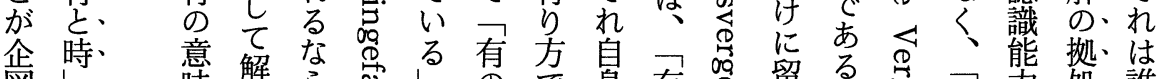

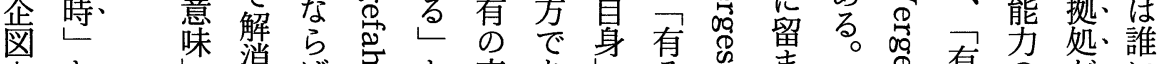

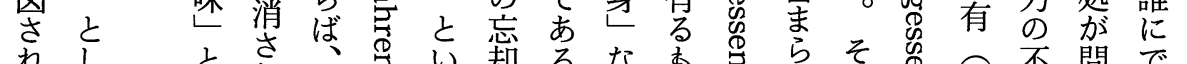

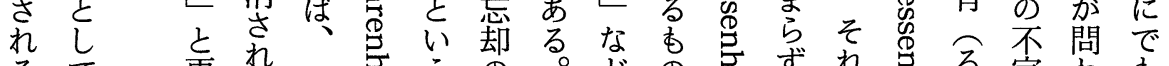

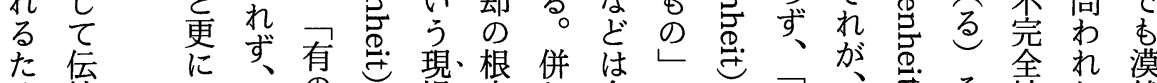

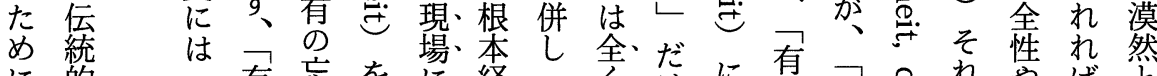

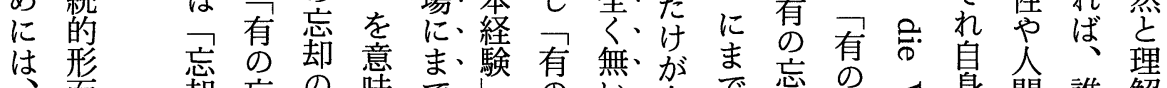

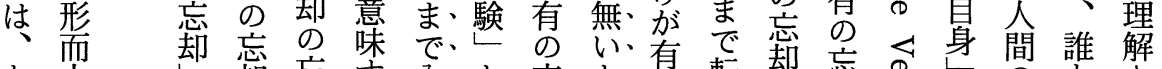

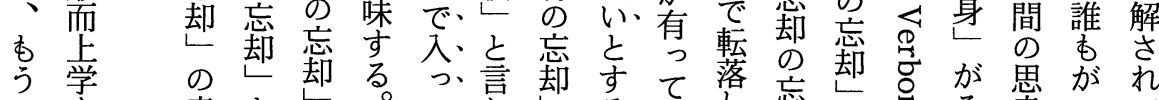

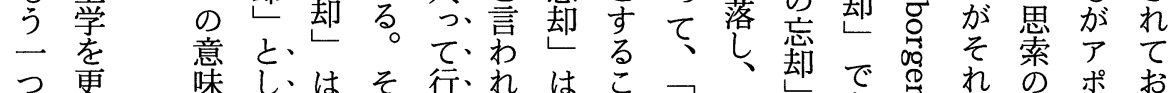

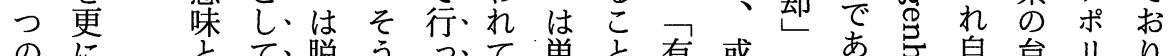

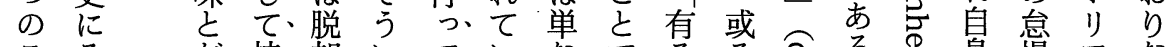

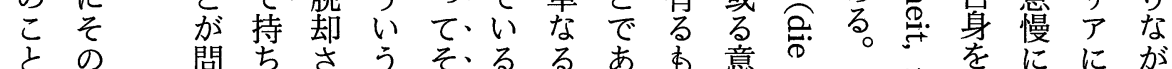

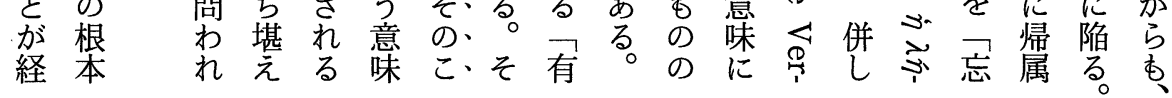

併初尔歴しし時 デ

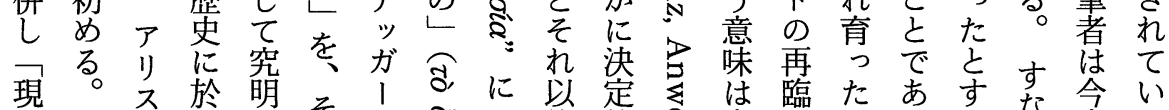

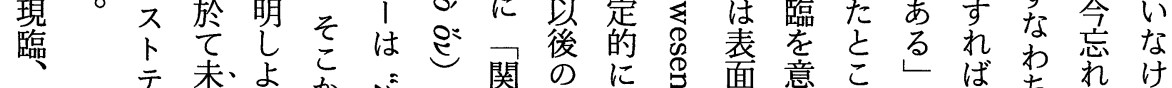

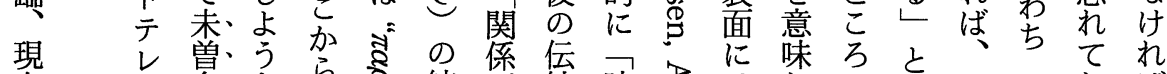

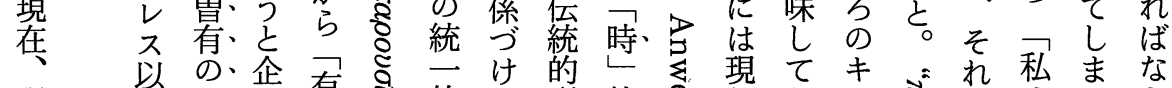

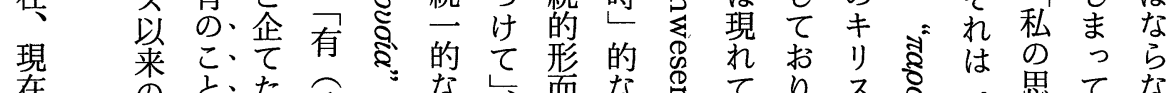

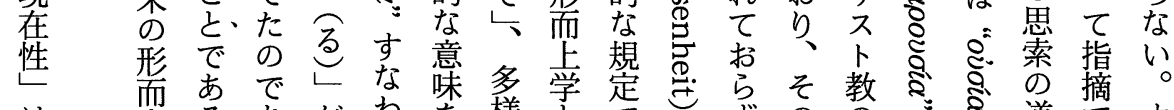

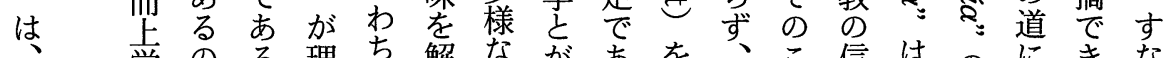

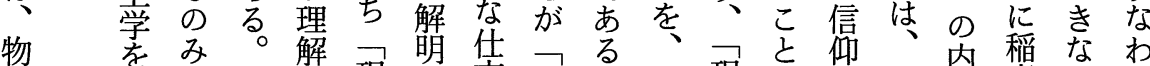

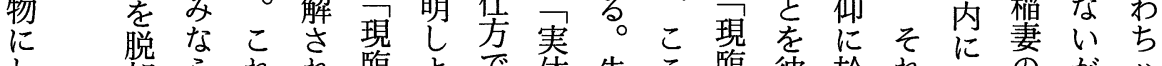

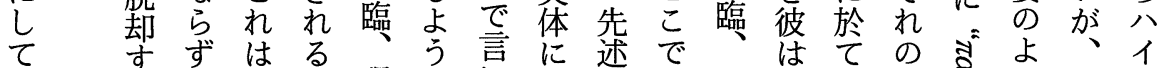

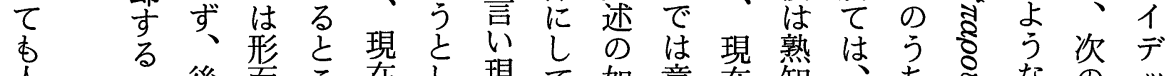

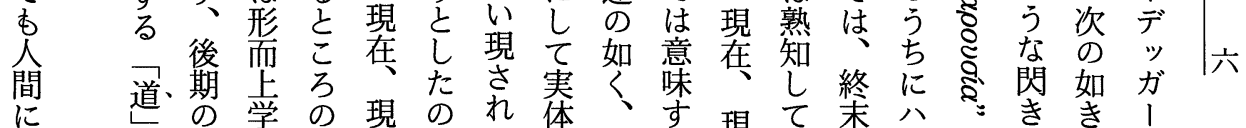

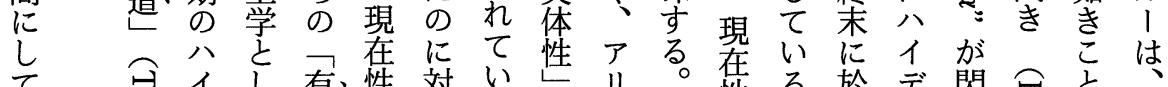

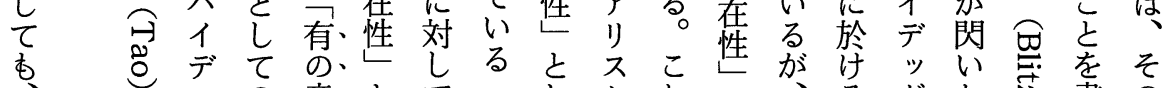
あ こデて

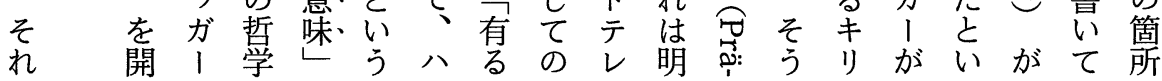




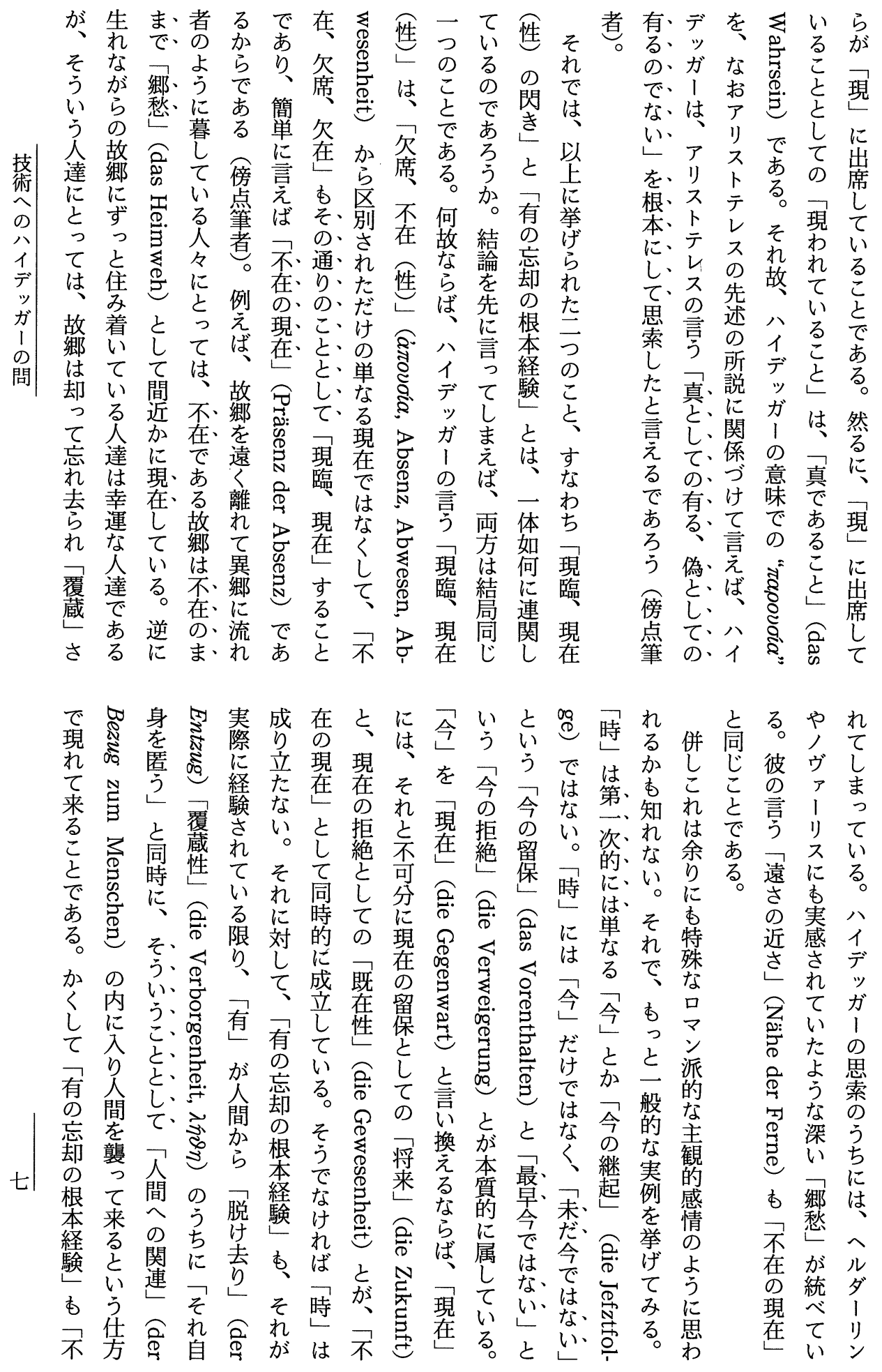




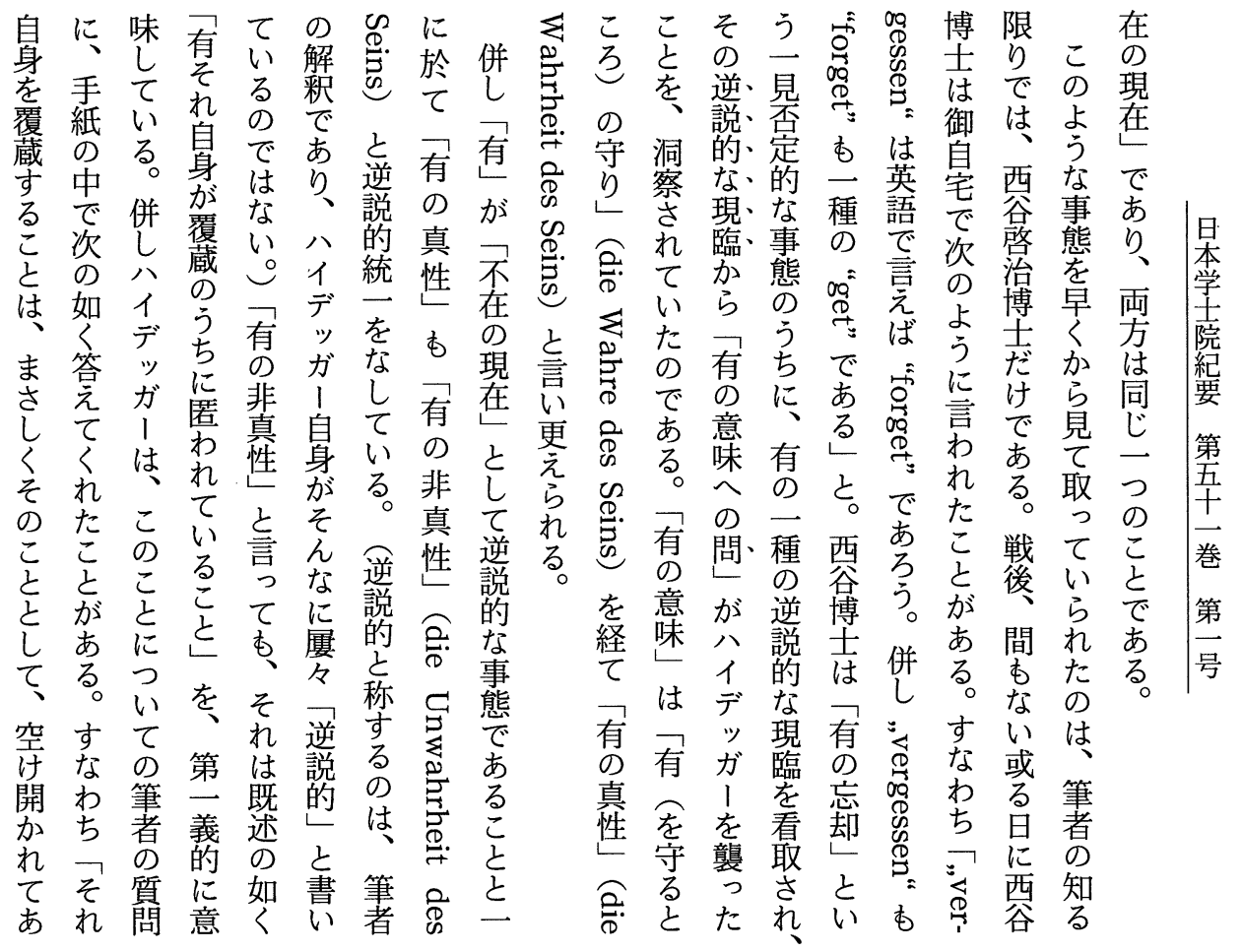

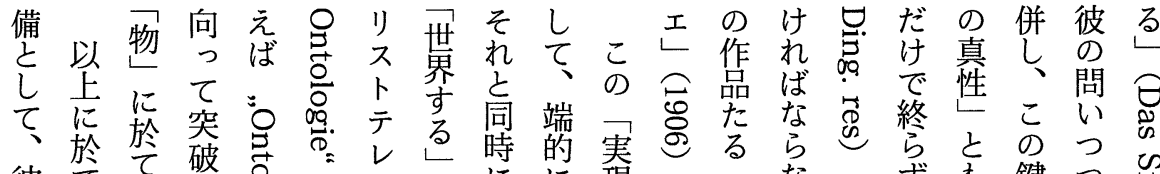

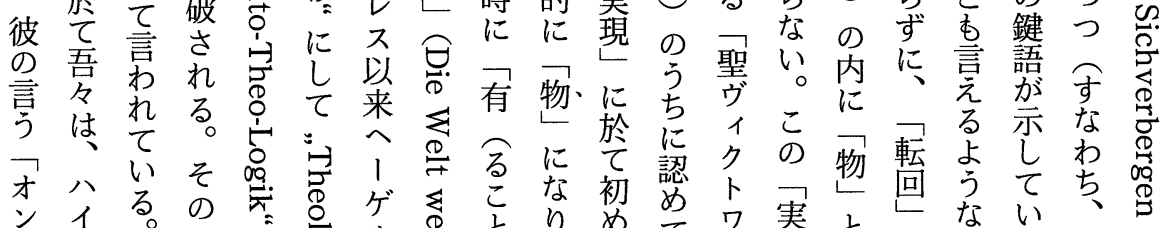
ト デ。 ギ シ 11 て

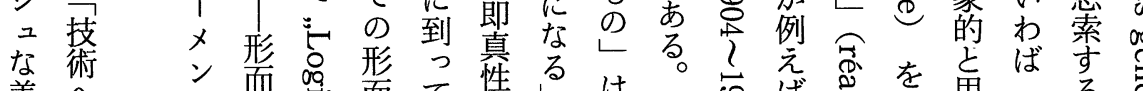

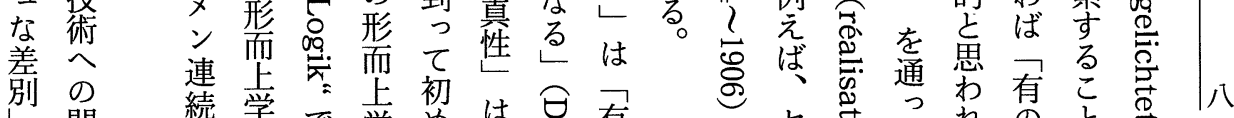

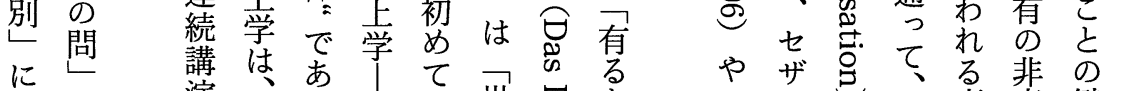

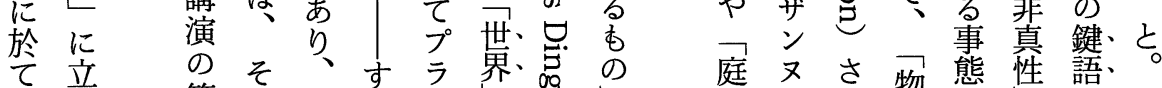

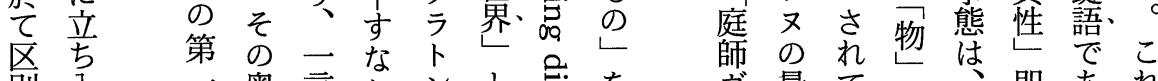

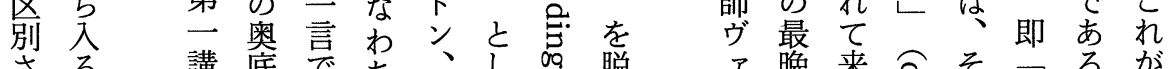

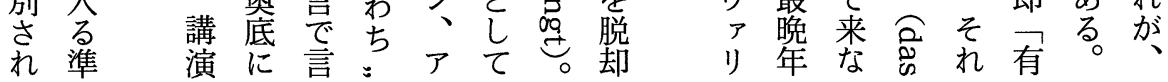




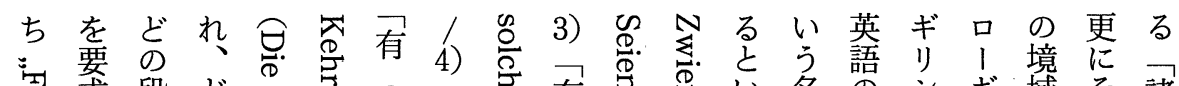

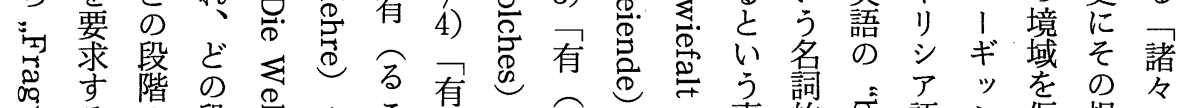

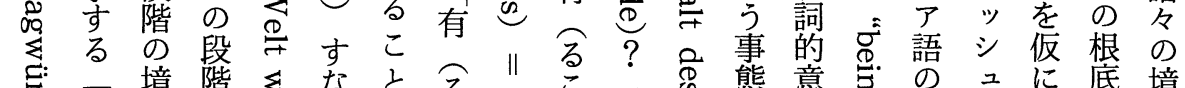

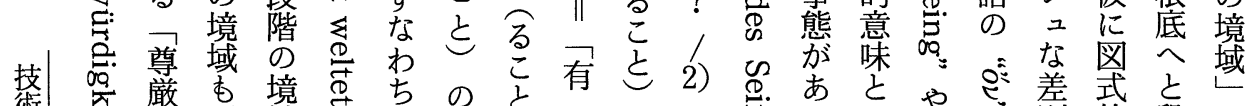

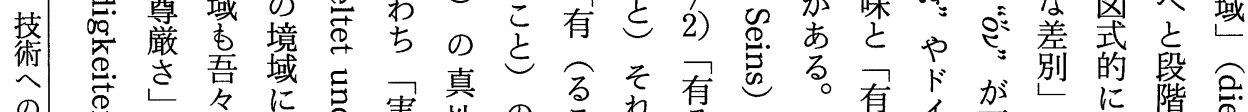

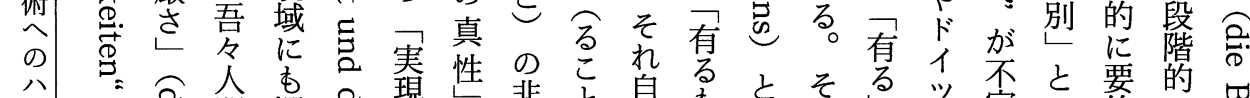

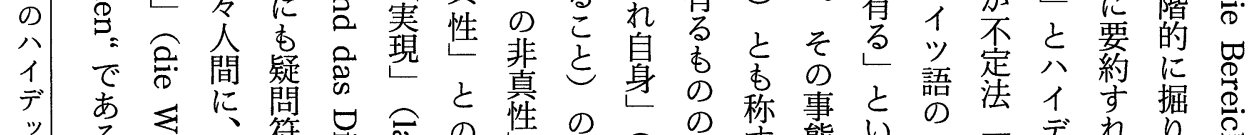

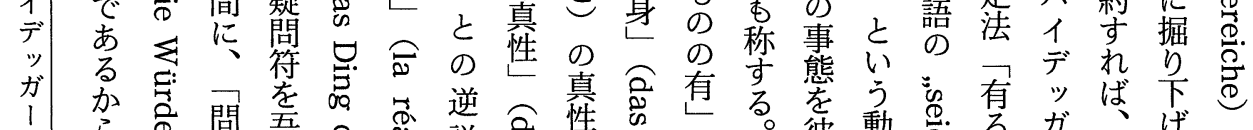

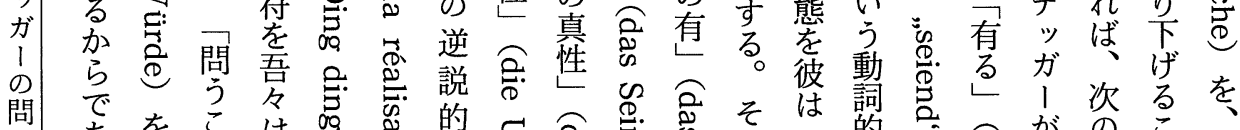

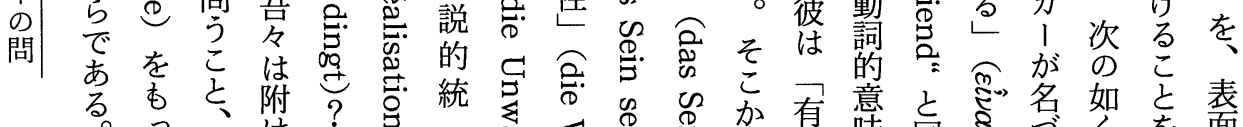

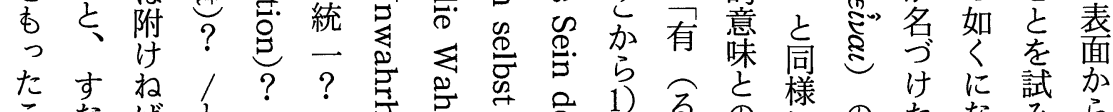
こなば之

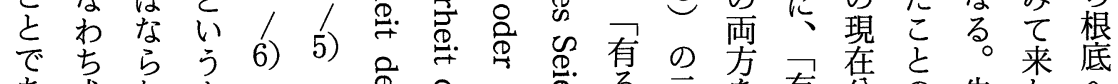

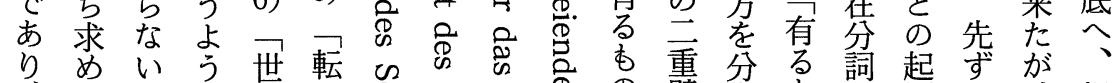

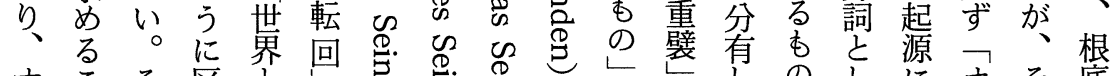

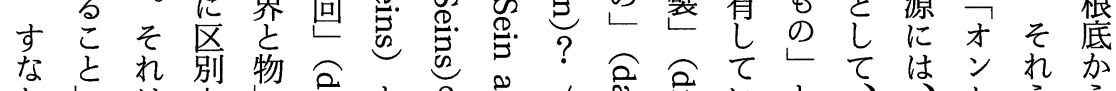

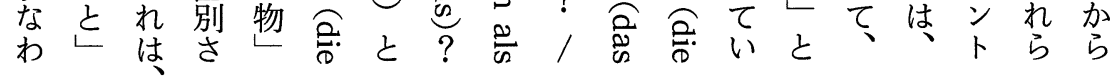

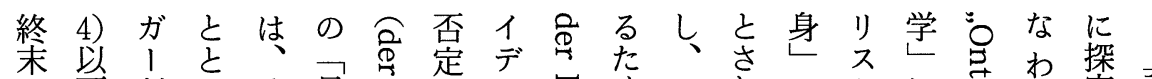

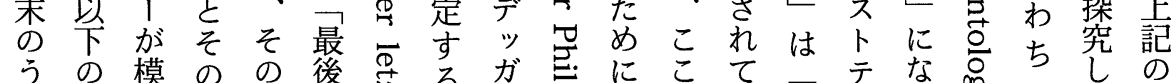
ち境範ここ

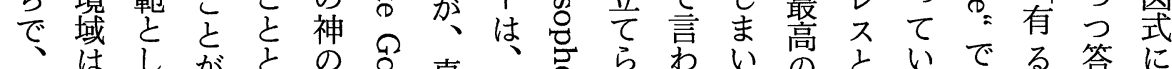

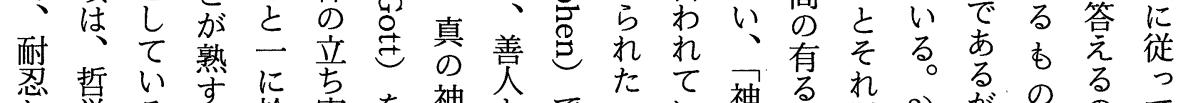

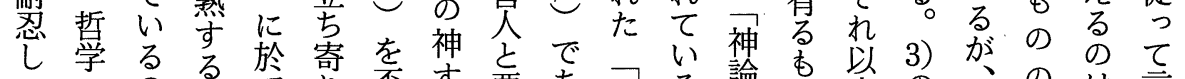
つ形は時てり歪す悪あっ神る論の来の 今の は言

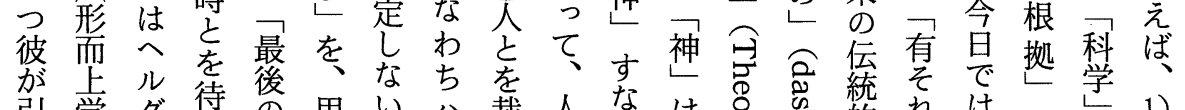

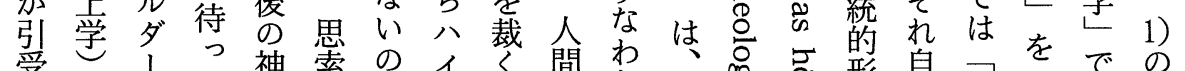
受 の リ て神索の

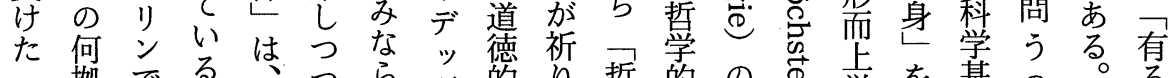

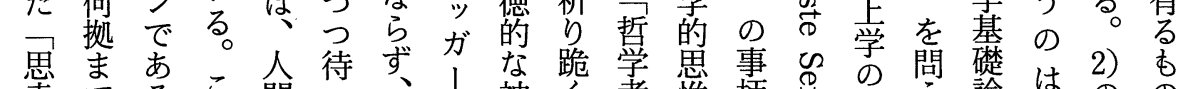

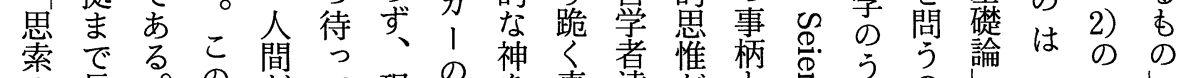

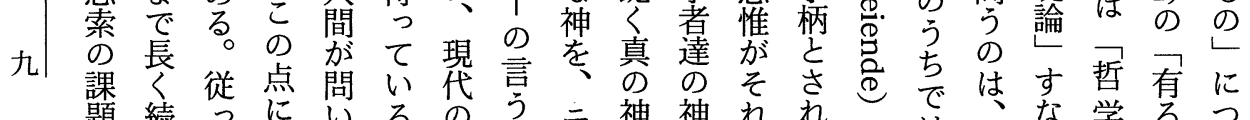

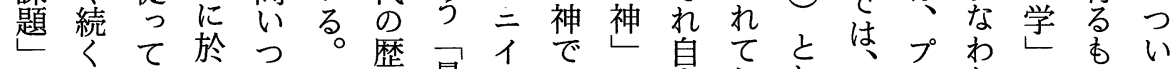

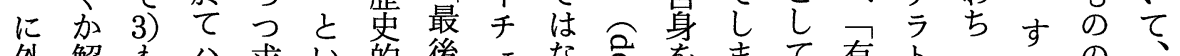

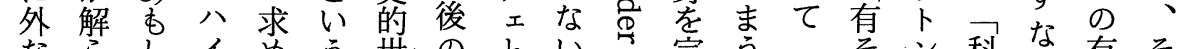

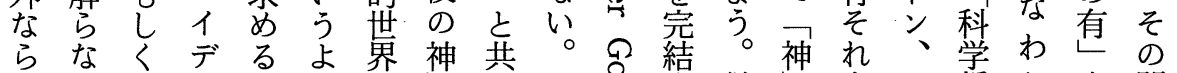

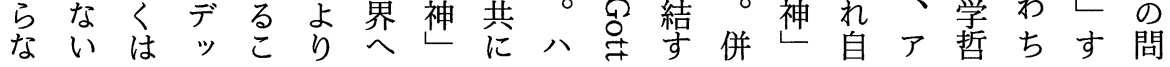




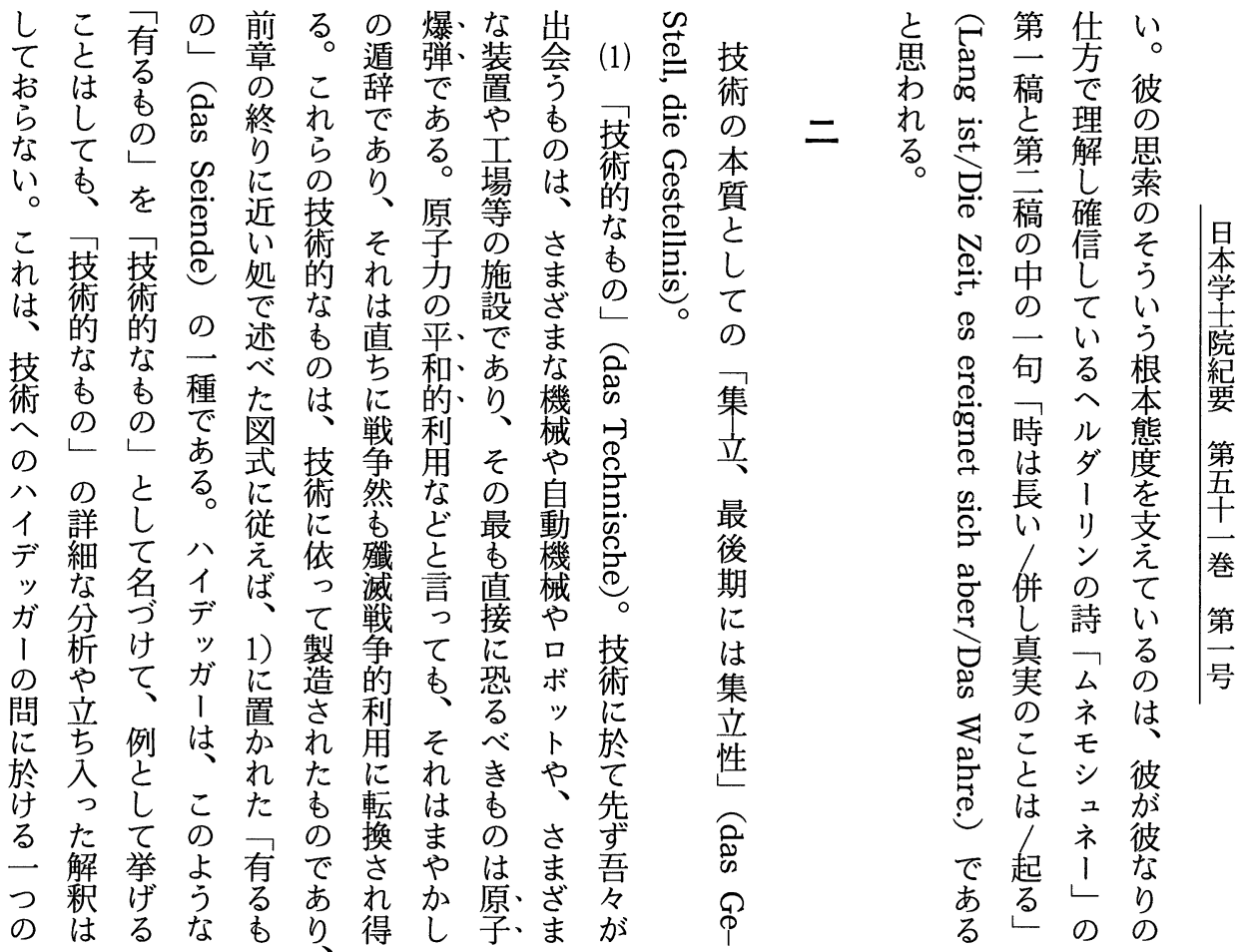

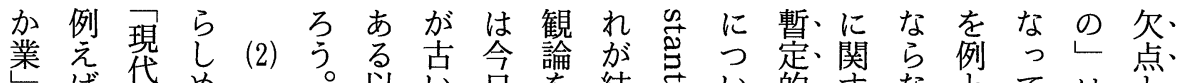

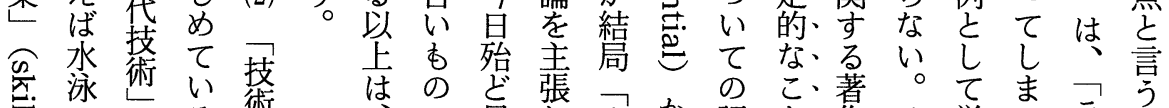

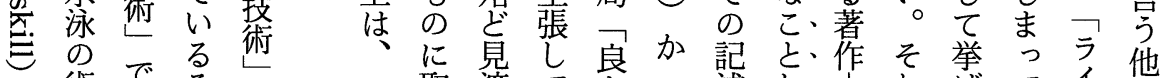

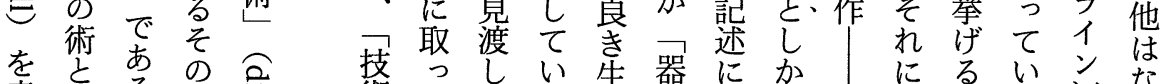
を意吕る。本怘術て得る活㽞終言之反場る河な 味高了質曰的替な狧的始完れし合。のい。

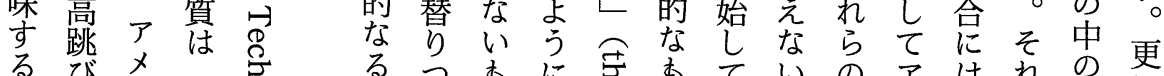
るび

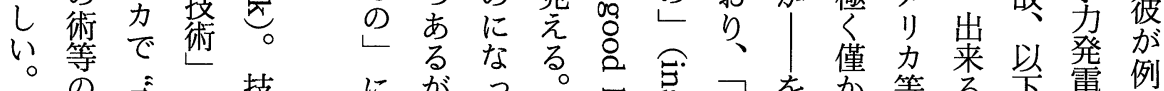

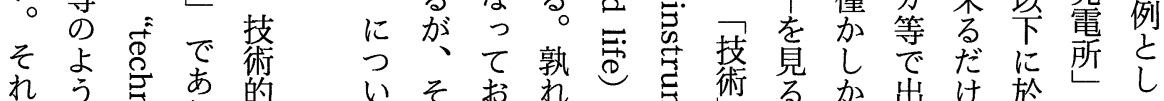

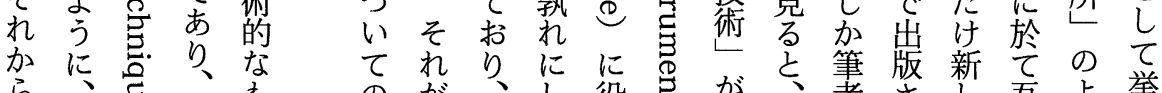

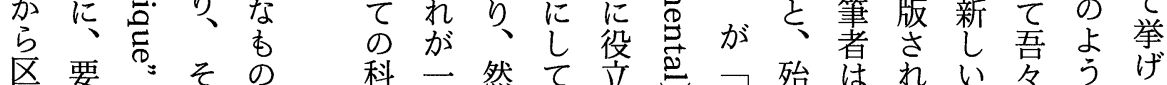

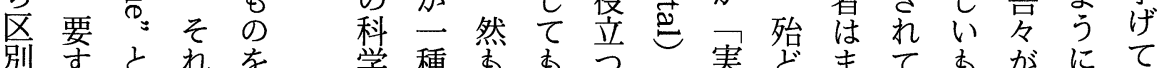

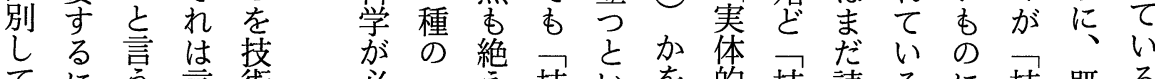
てにう言術必有䇺技いを的技読るに技既る

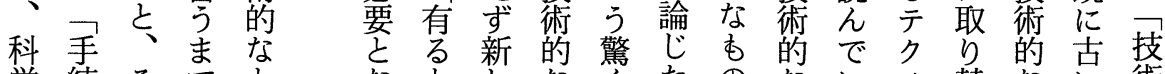

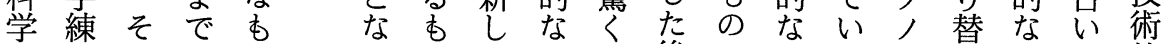

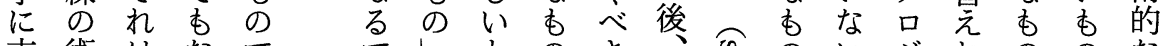
支術はなで な゙て 


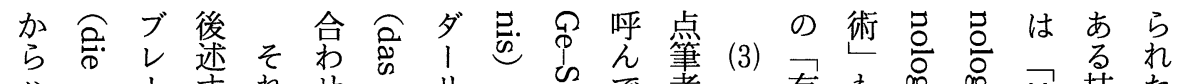
公

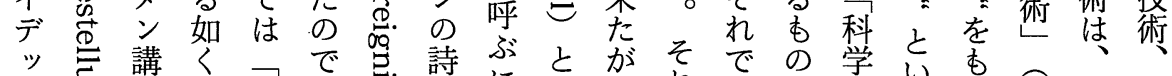

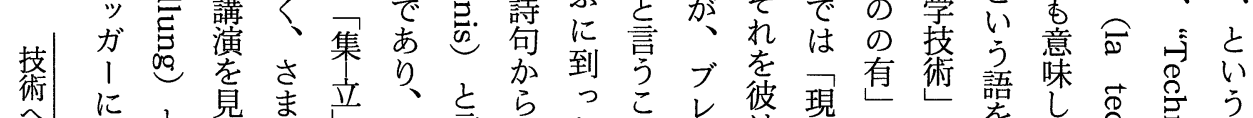

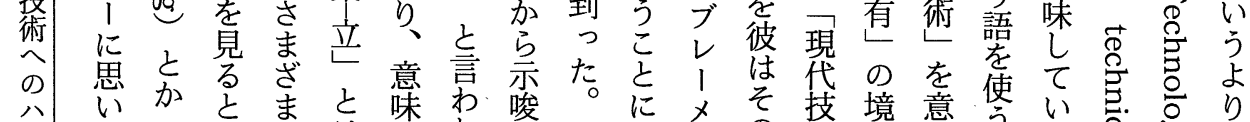

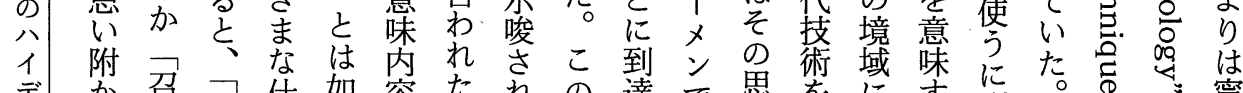

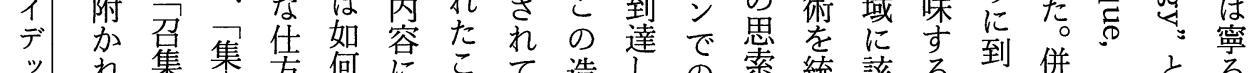
ガれ集立でな於とて造しの索統該る到併气と方

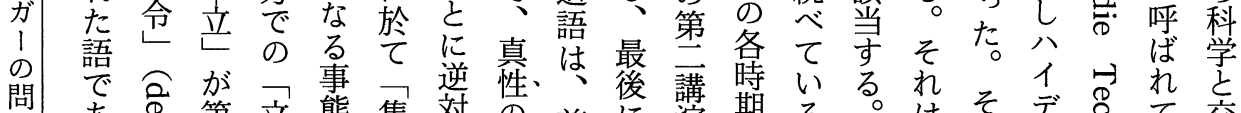

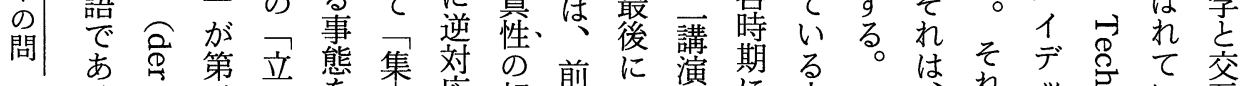

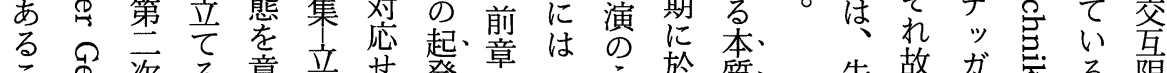

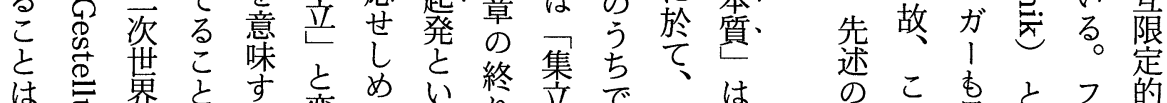

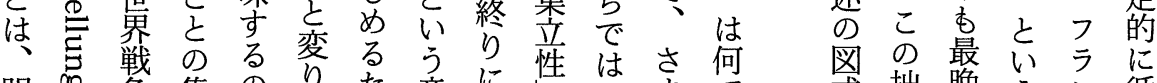
明恕争集の品た意に性はさ荷式拙晚うシ循

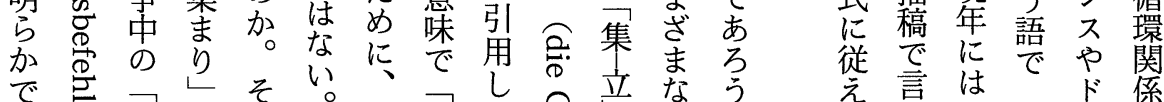

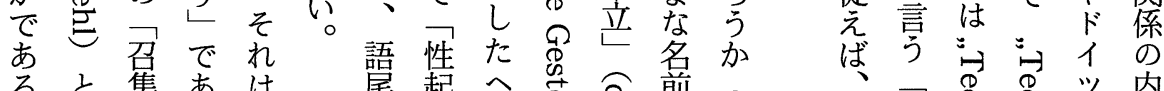

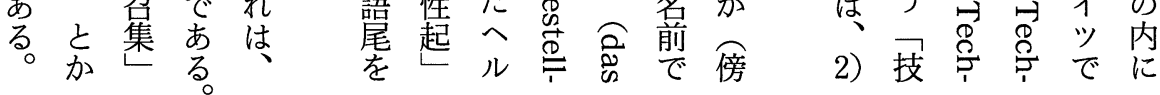

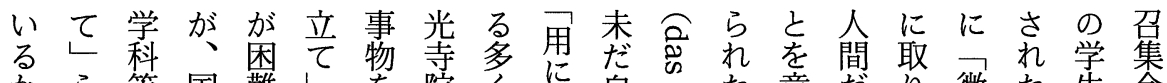

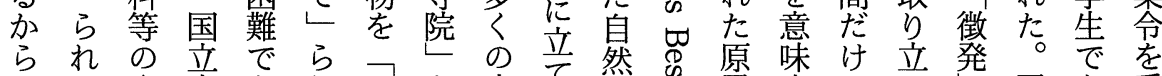

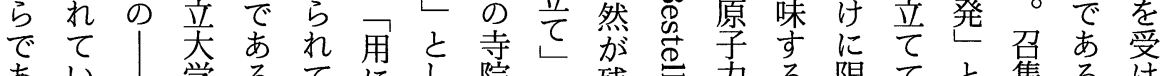

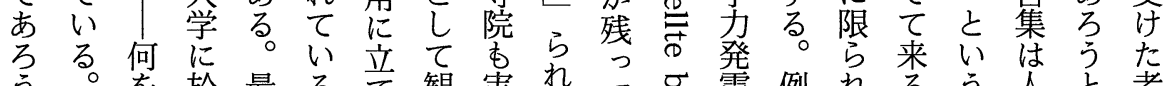

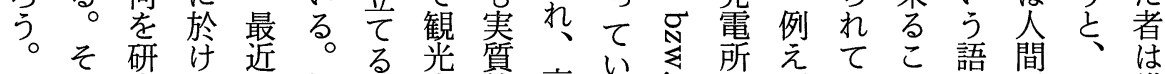
最机究るの無者産的京る。の怘扔と㤎軍誰

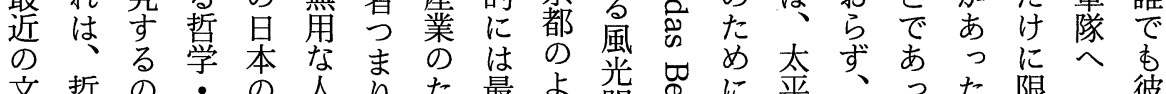

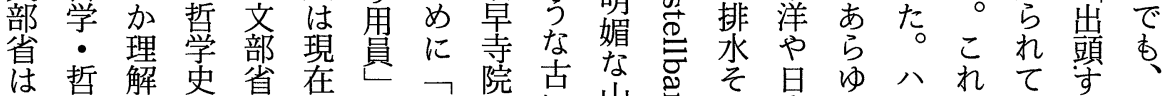

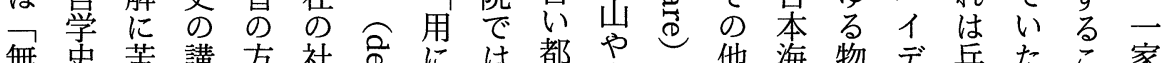

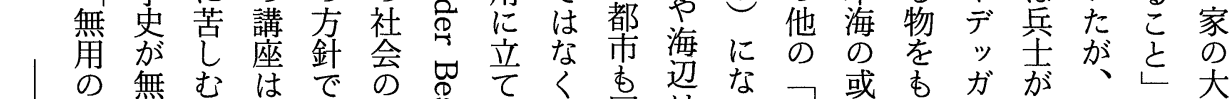

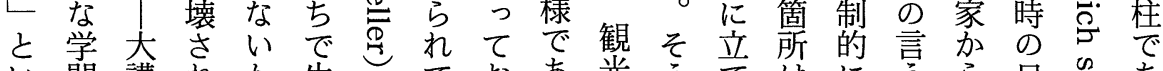

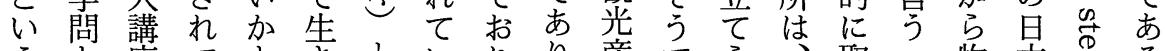

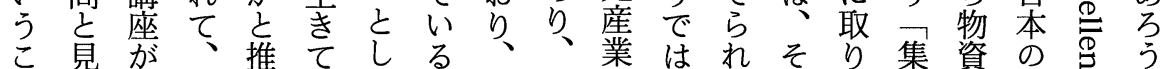

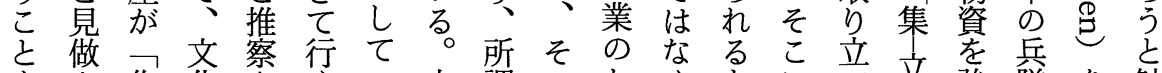

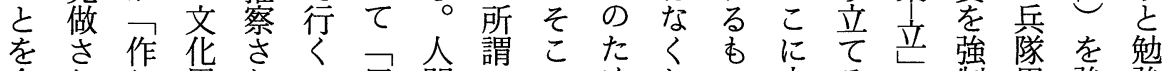

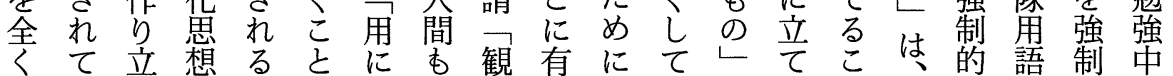




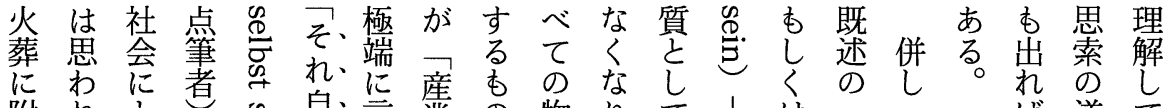

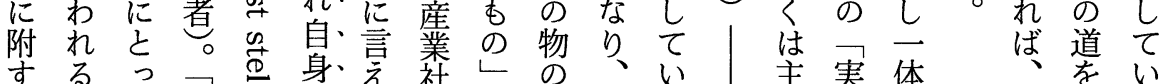
る。

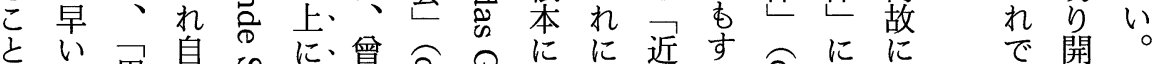

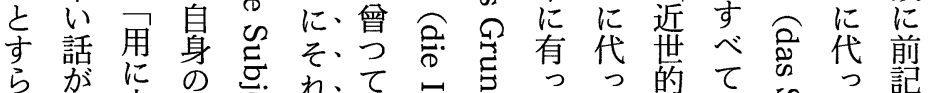
否苦立上

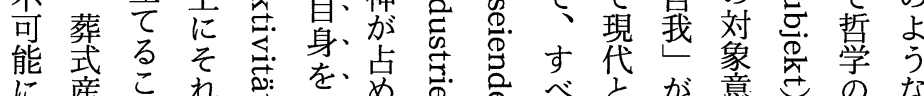

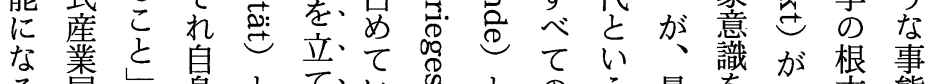
る屋は身とててい邑と怘う最を統自問態 怒本立て主地号う真認示題起

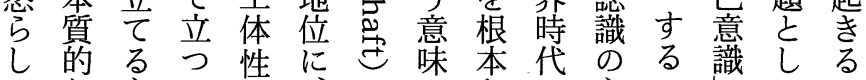

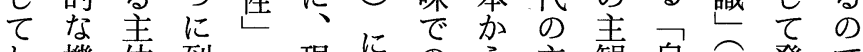

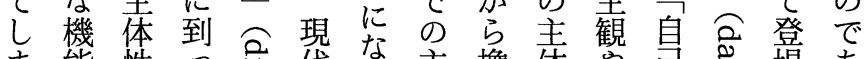

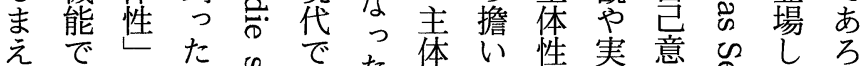

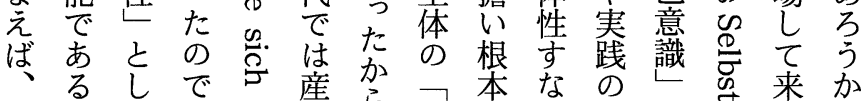

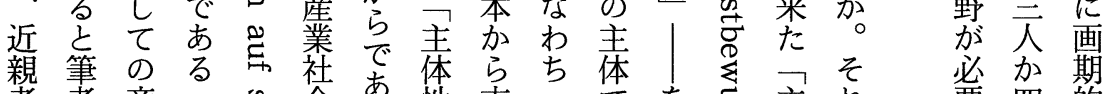

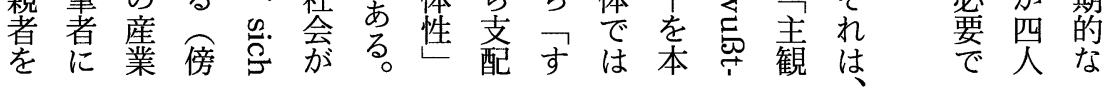

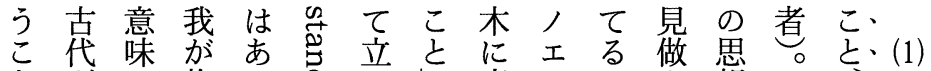

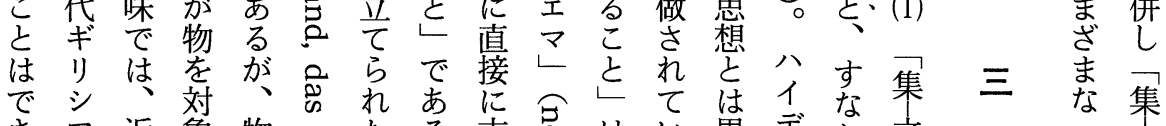

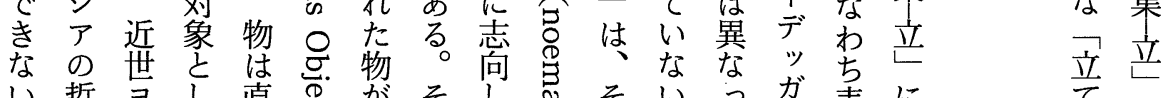

し哲寻学

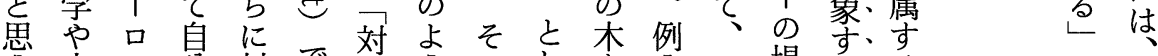

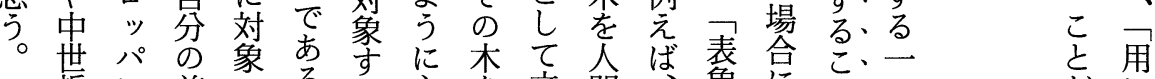

哲に前でるな主を立間家象にと、つ怘に

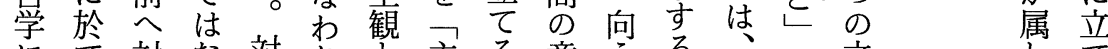

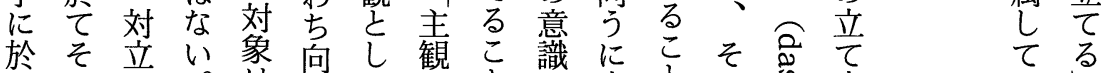

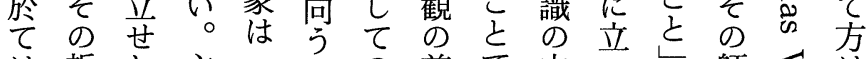

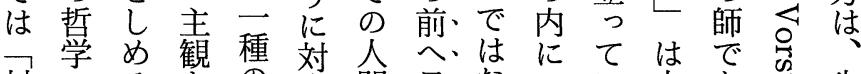

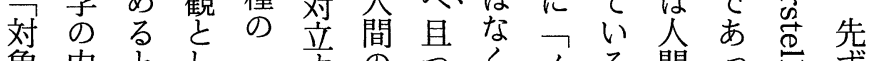

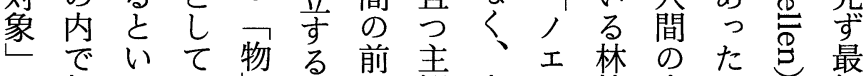
之起うの物 合観向 シ 檎意フ初

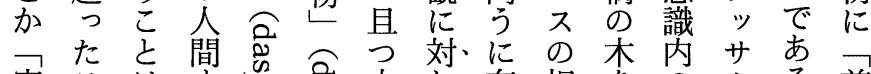

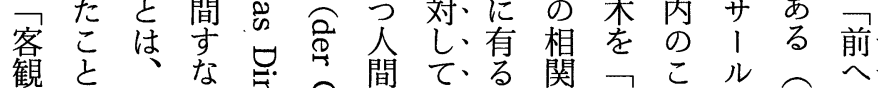

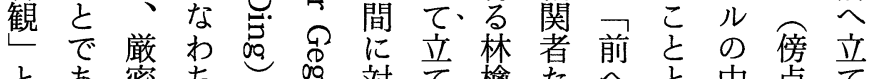

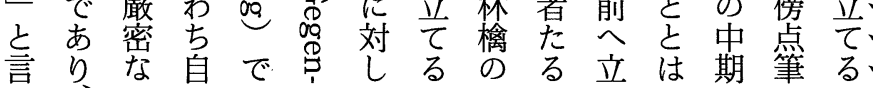




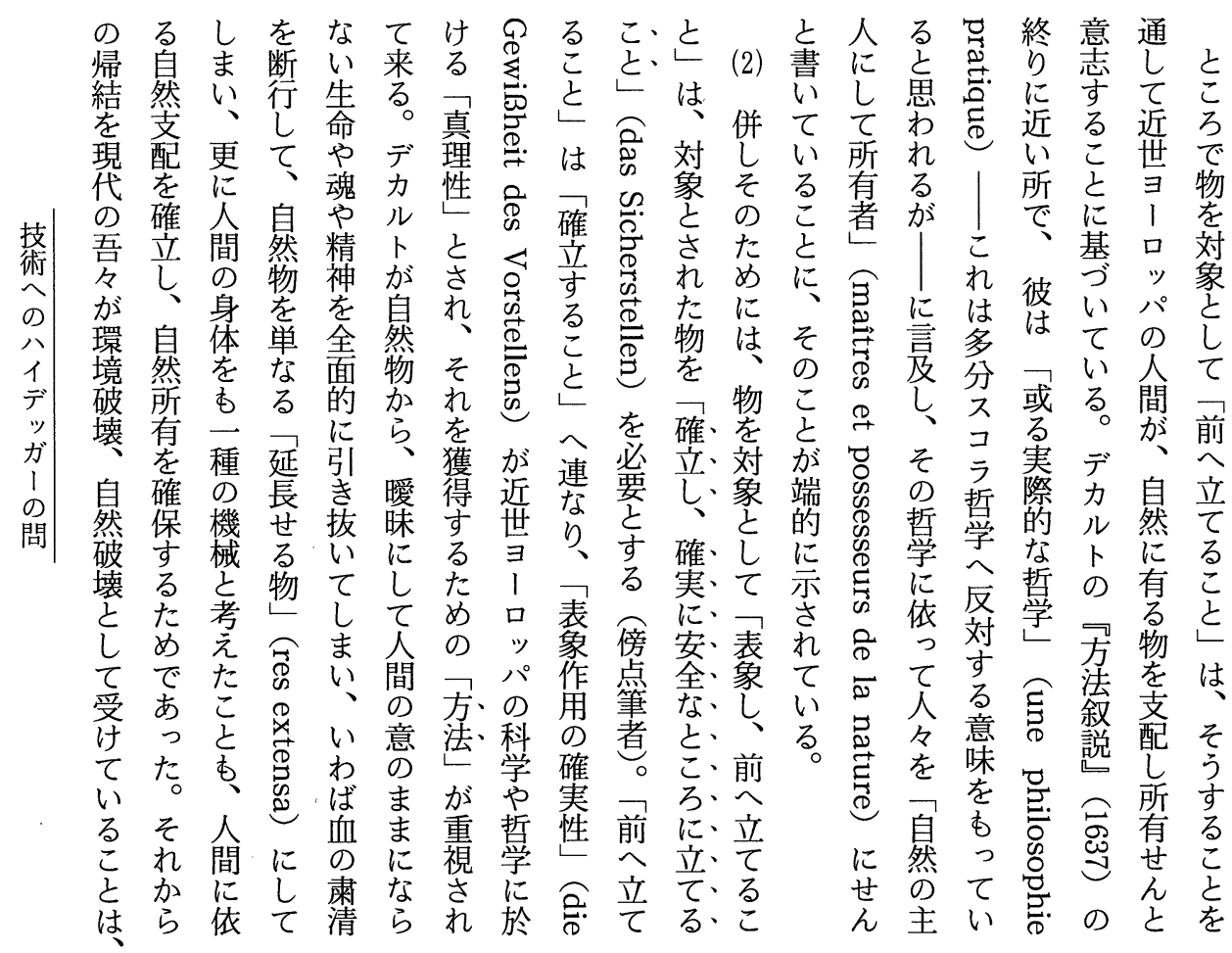

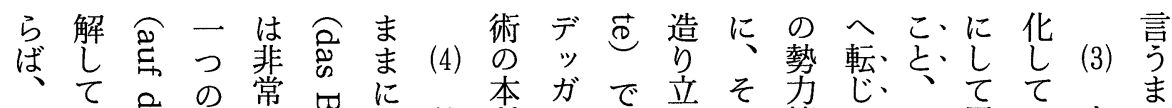

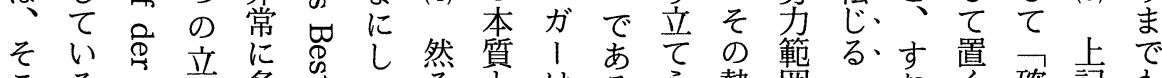

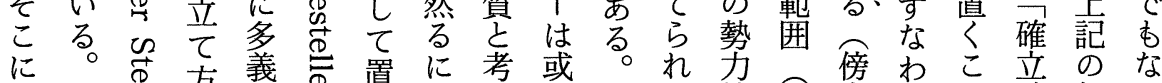

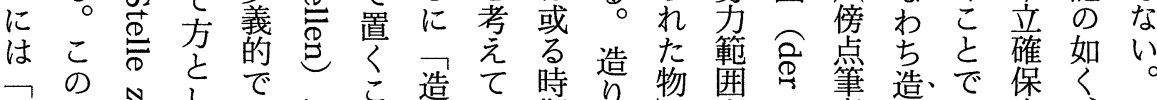

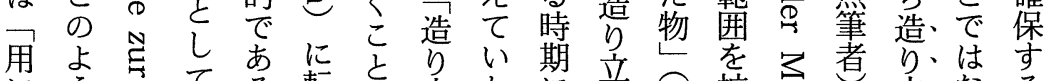

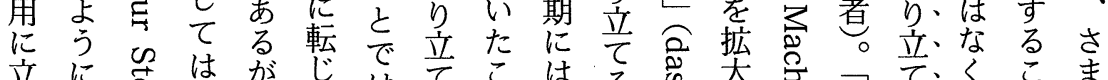

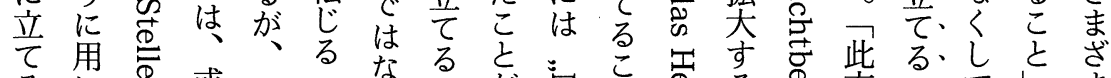
るに こ 立菅 物

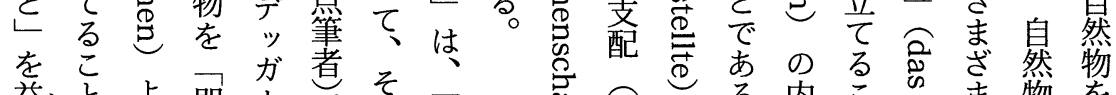

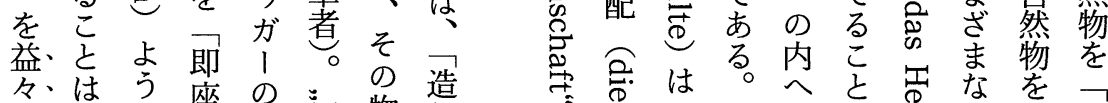

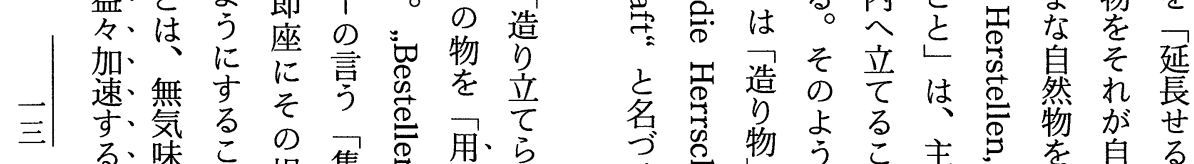

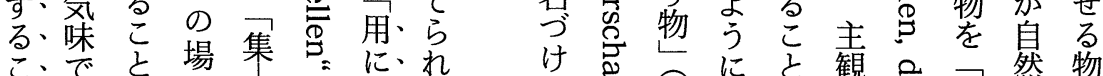

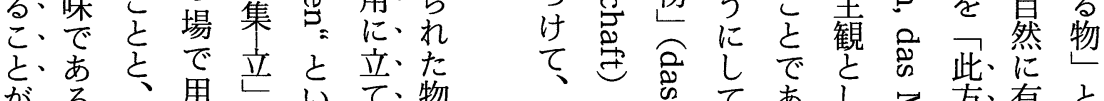

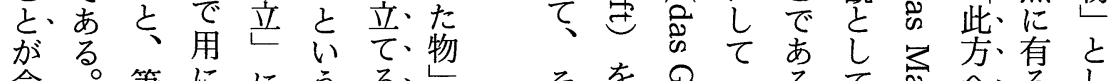

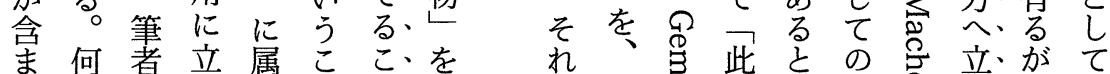

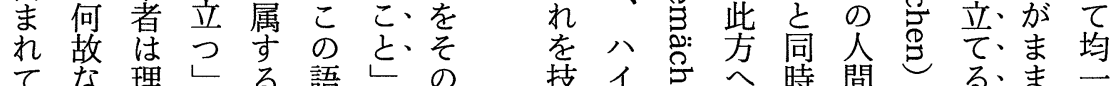




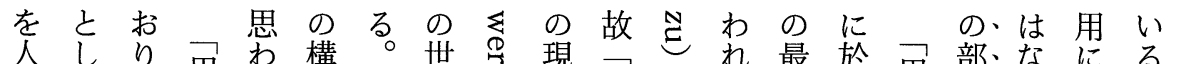

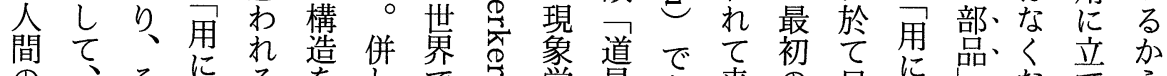

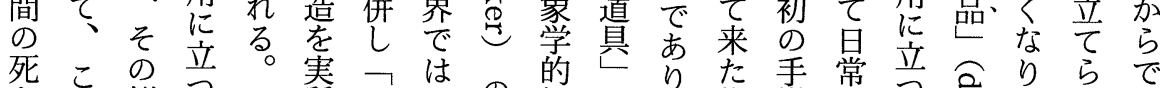

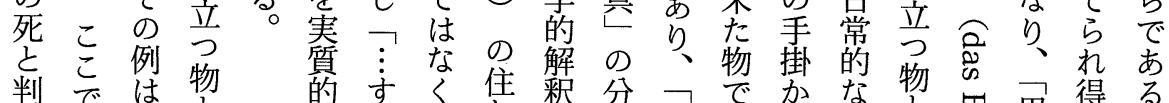
判では物的すく集粉分手で加な物四用得る

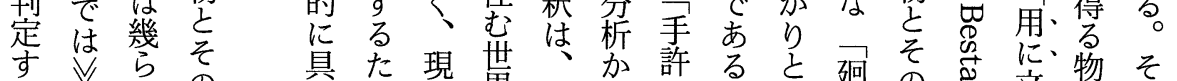
る

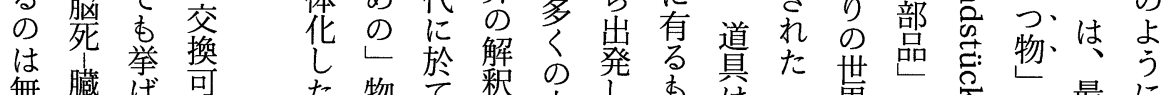

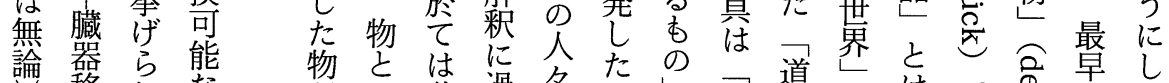

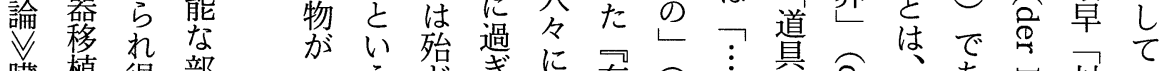

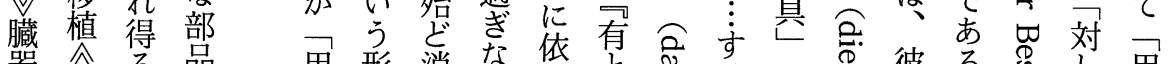

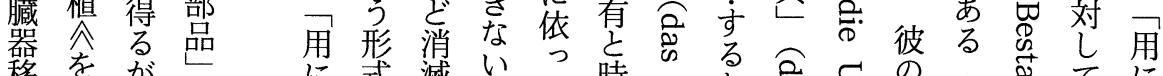

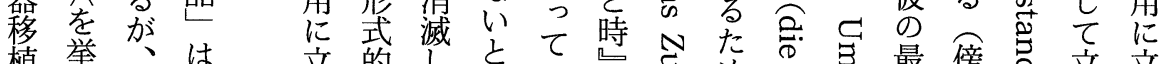

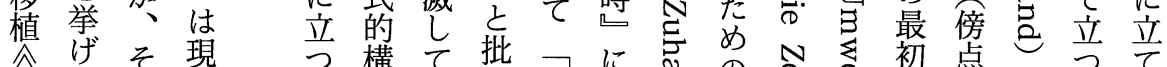

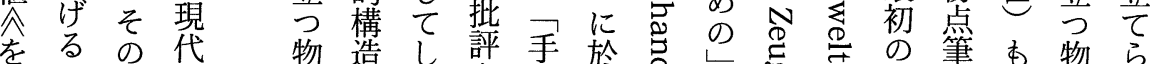

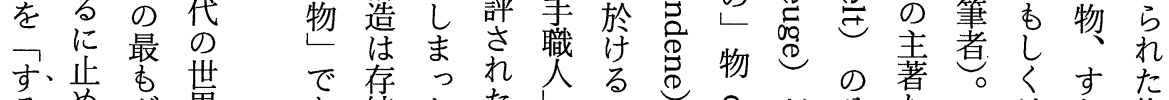

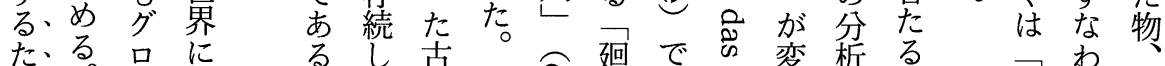

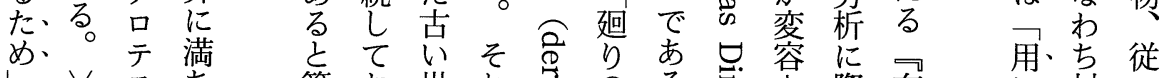

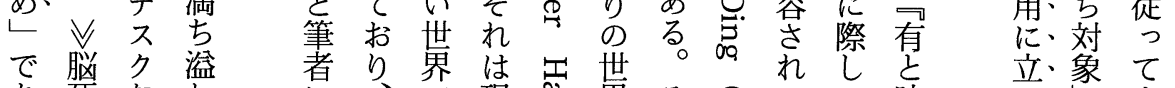

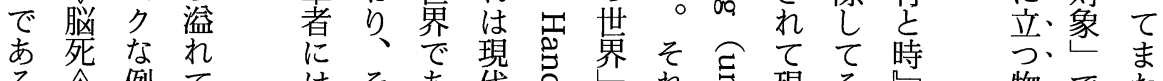

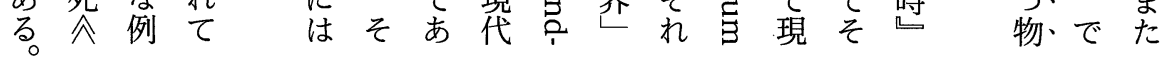

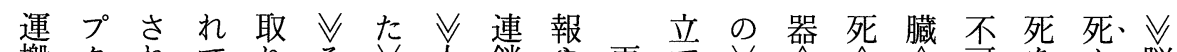
搬多卆て

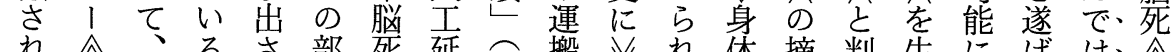
れ、令さ部死延气搬 $、$ 体摘判生にげは、令

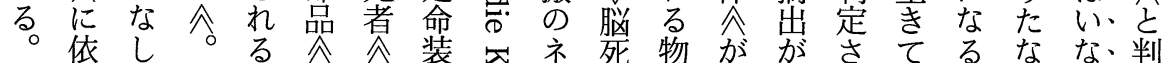
運つ得 $、$

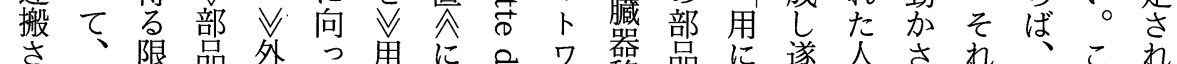
さ限品外つ用に另ワ器品に遂人され机これ

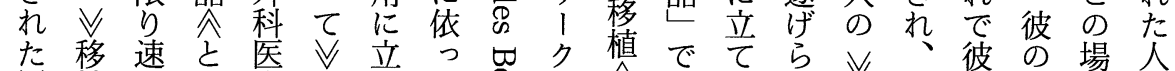

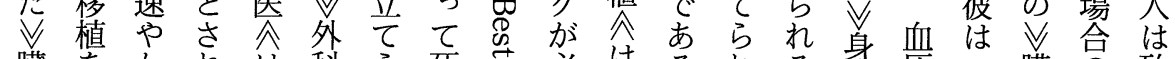

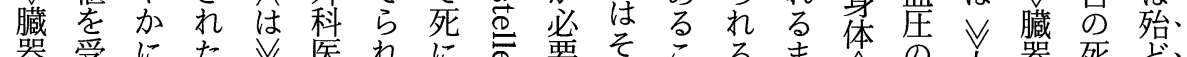

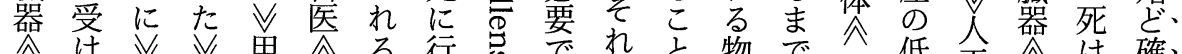

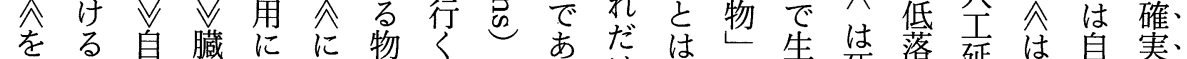
患動器立依食こをるけ多で名落延新然に、

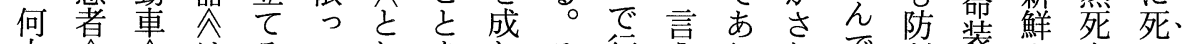

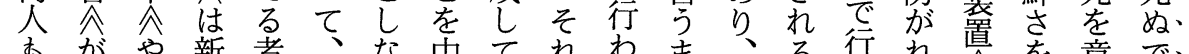
あがや新者、な中てれわままる行れ真を意で、 待待 $、$ 鮮食なけ断いはれでそのくて合失味あ、

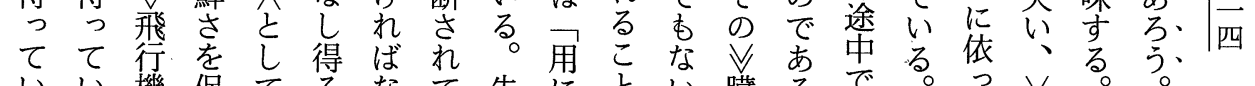

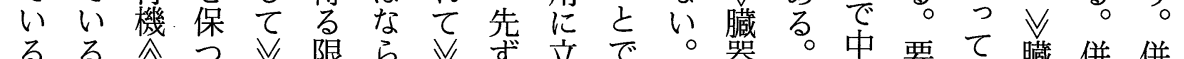

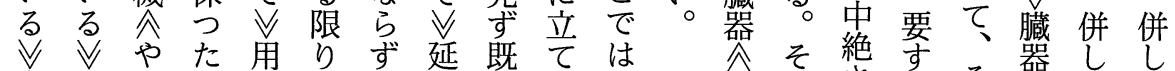

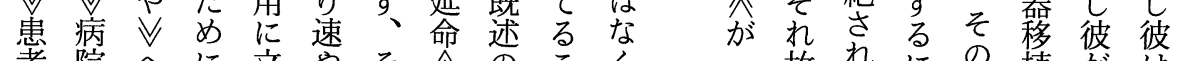
者院

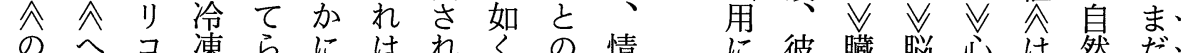




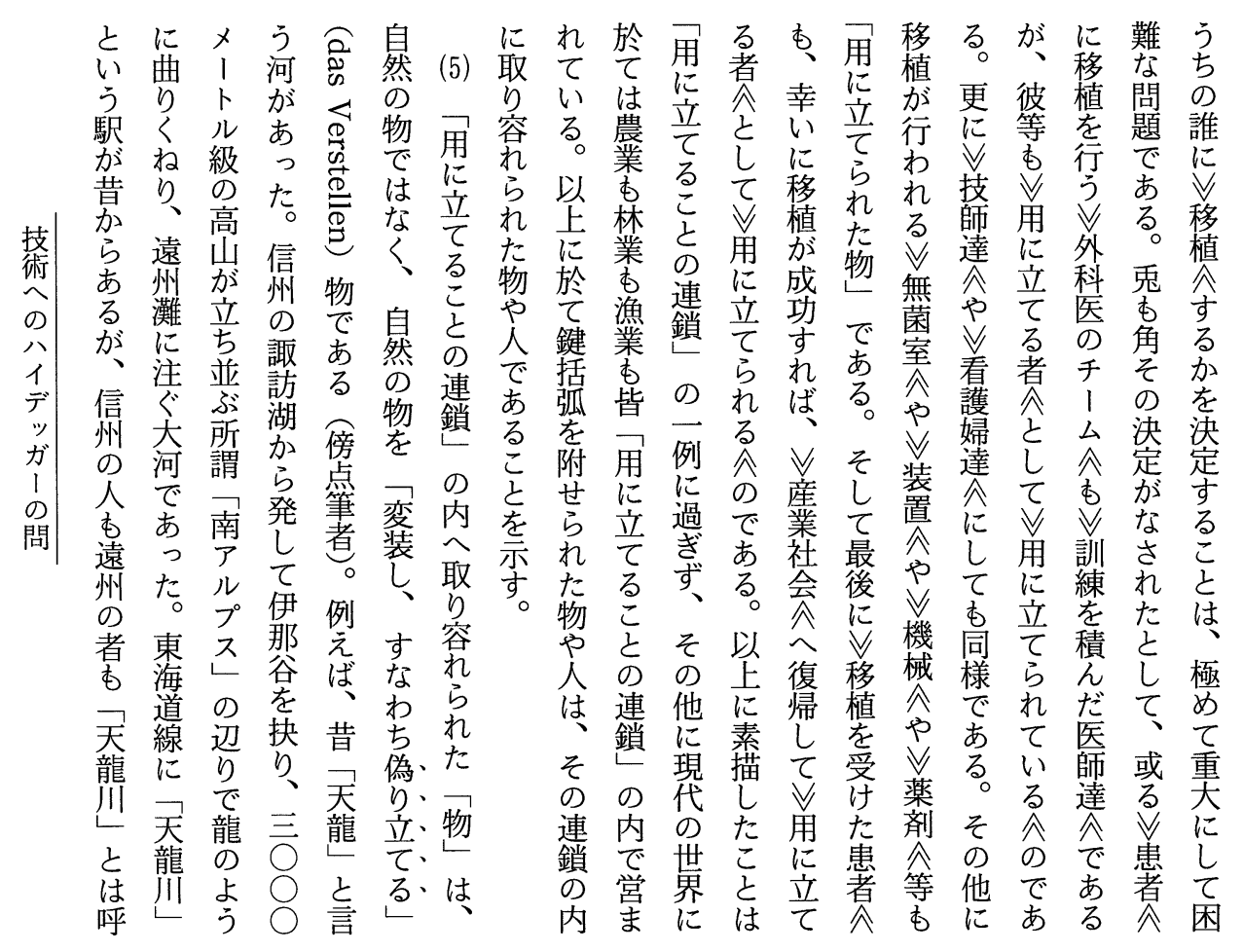

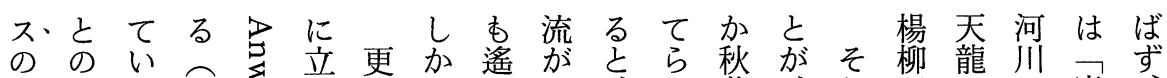

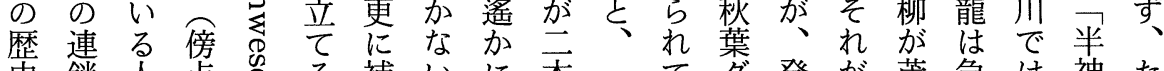
史鎖人点㞧補いに本一て多発が茂急は神た

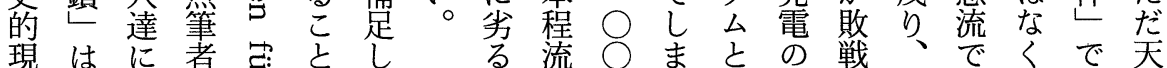

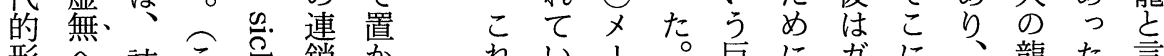

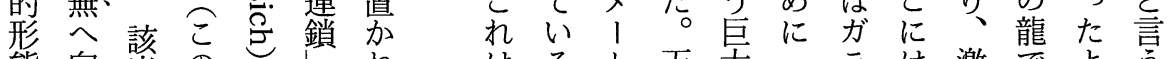

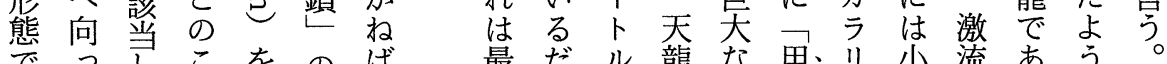

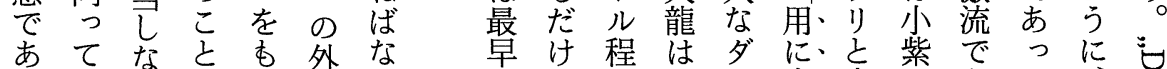

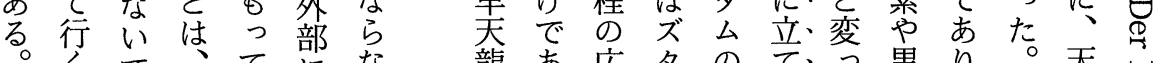

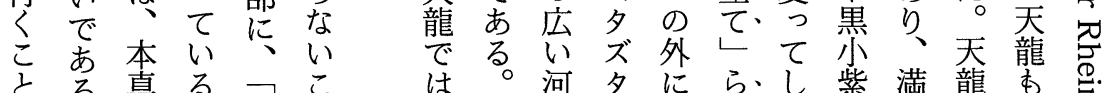

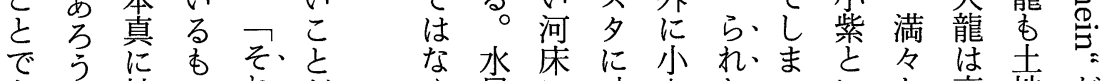

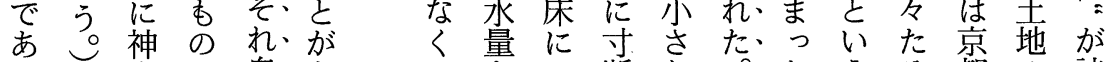

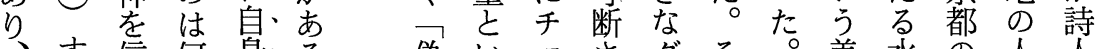

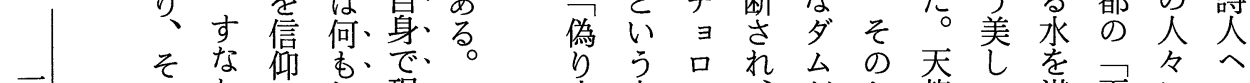

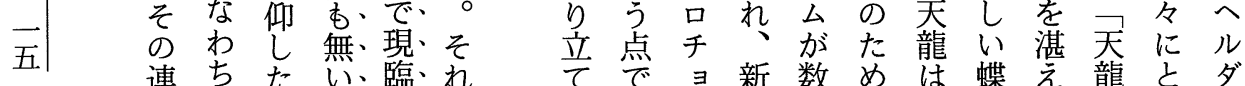

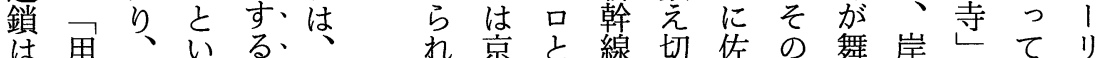

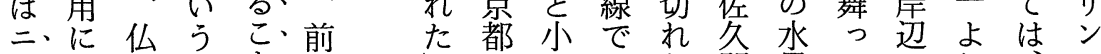

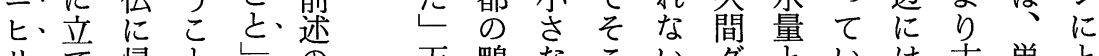

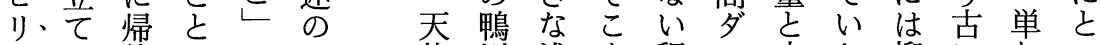

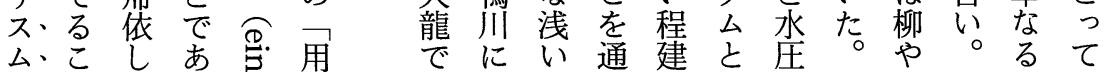




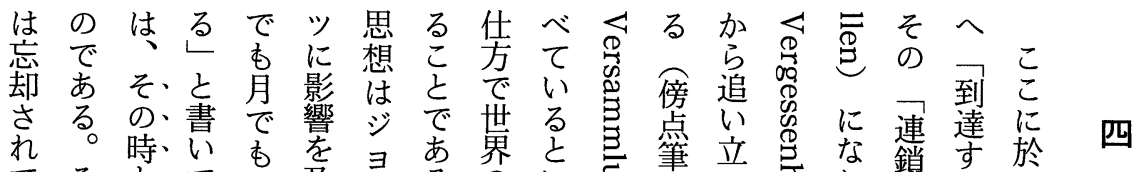

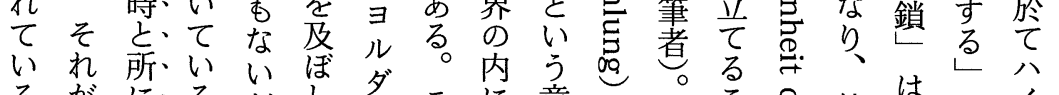

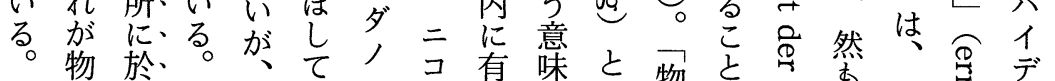

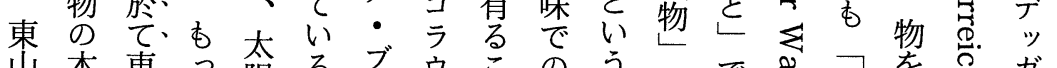

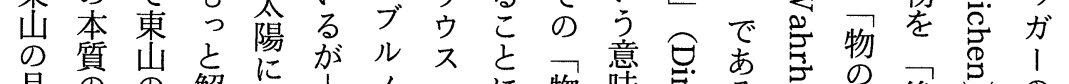

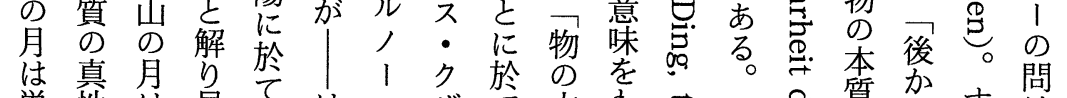

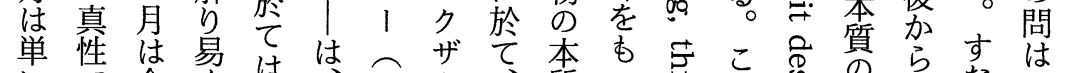

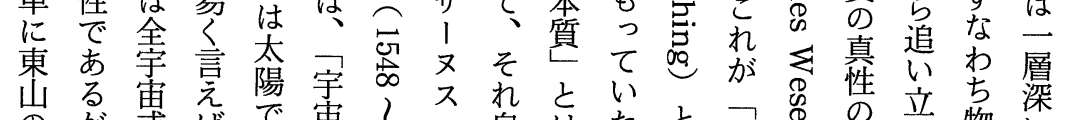

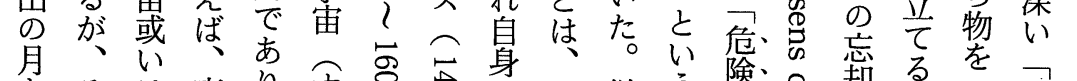

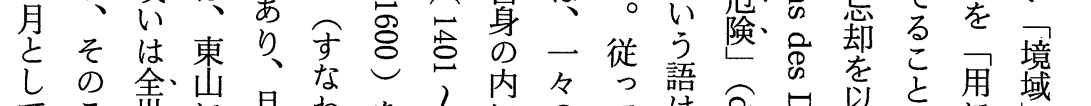

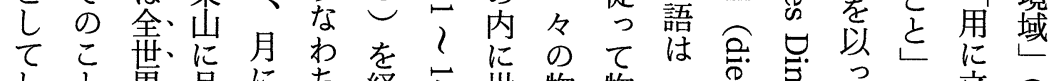

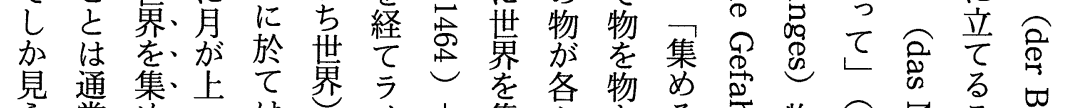

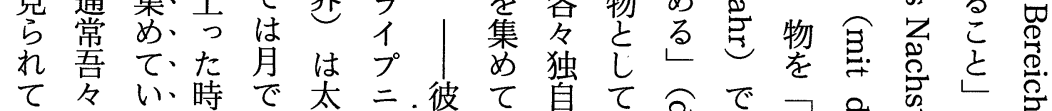

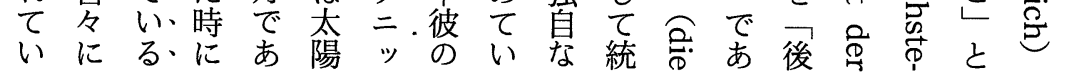

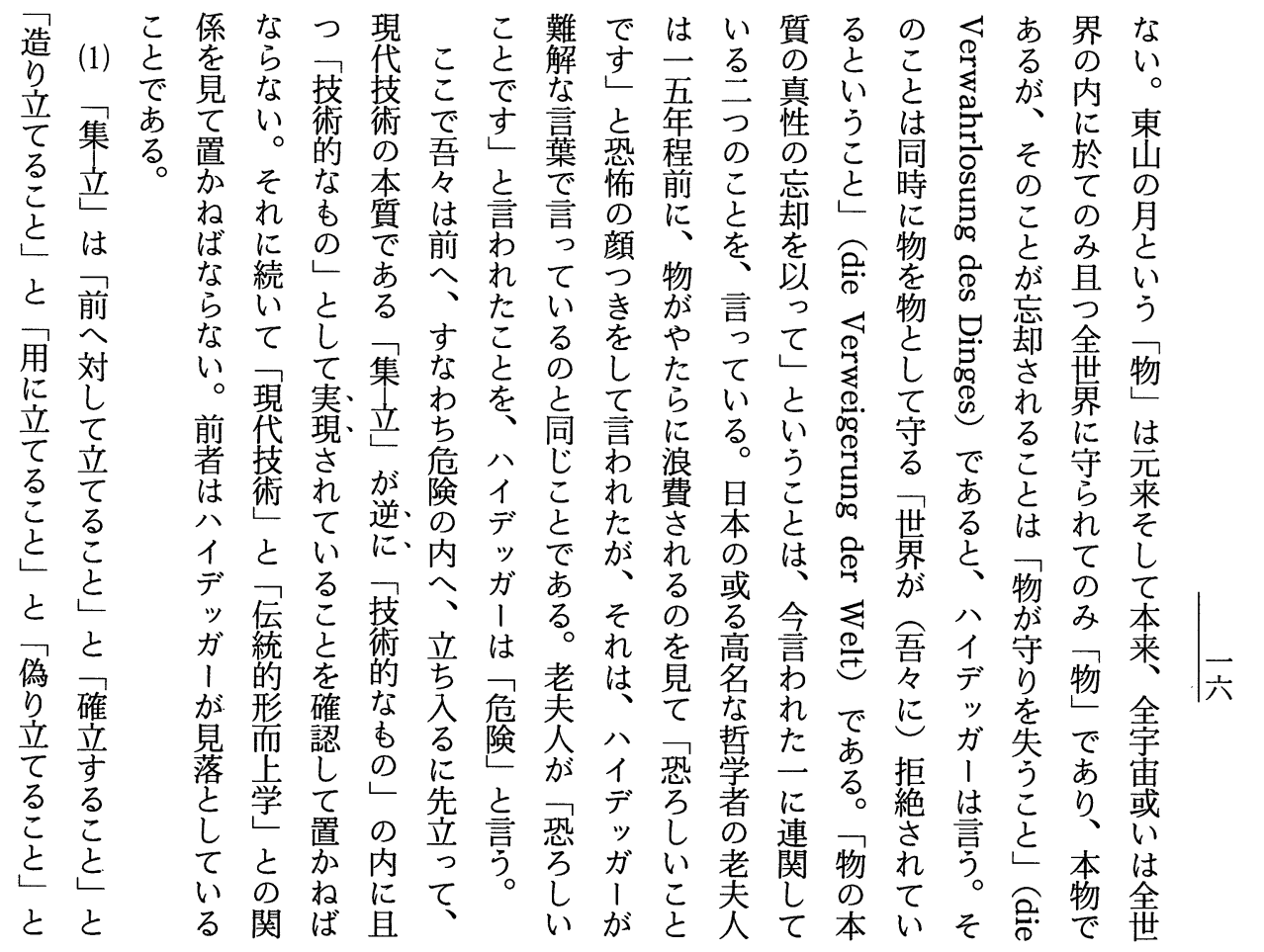




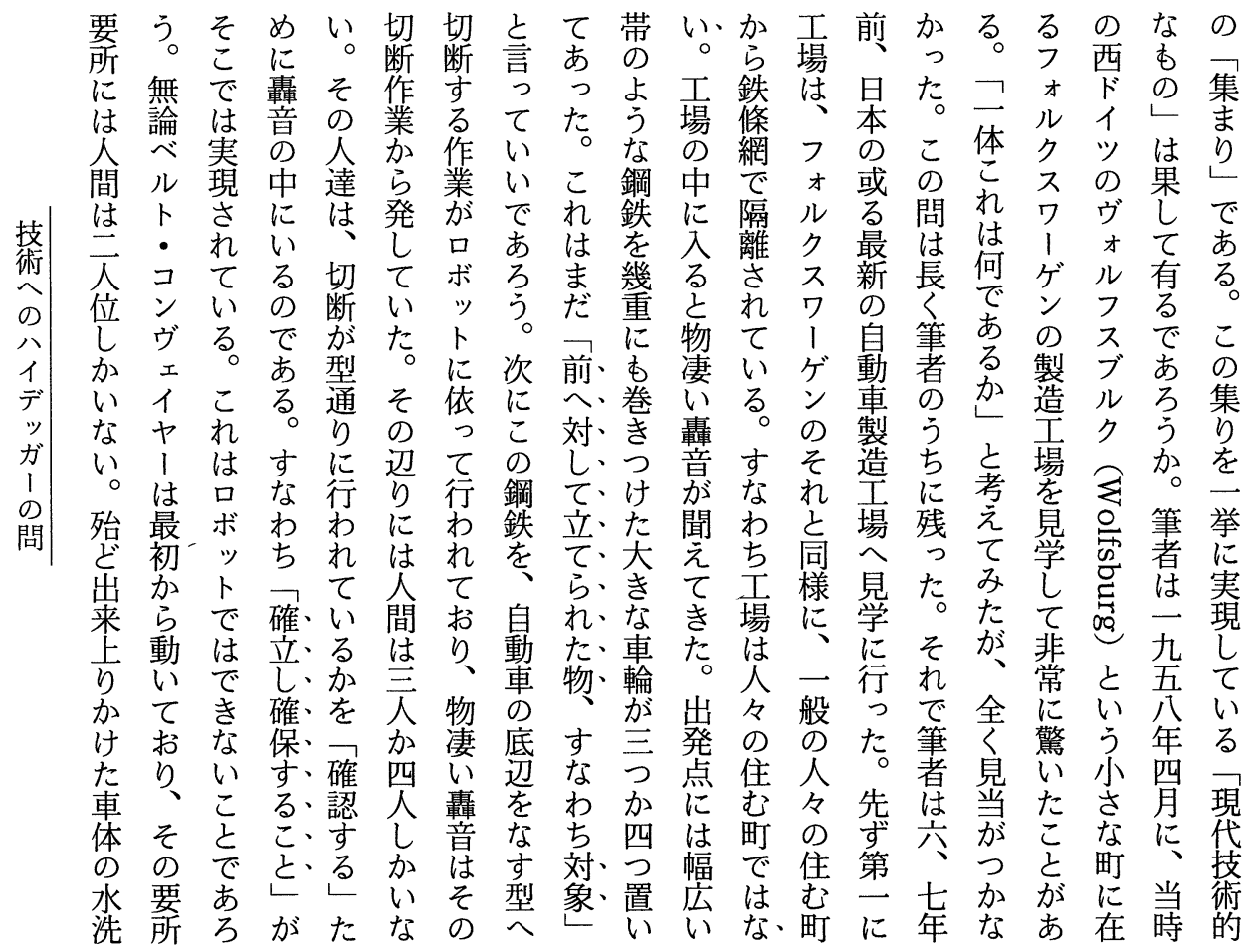

処常ワ狭駄筆で内作否これ告純亏動にヤな

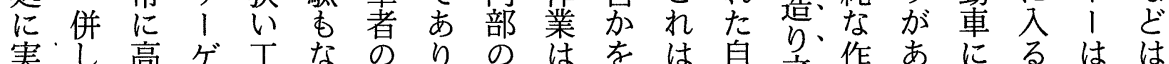

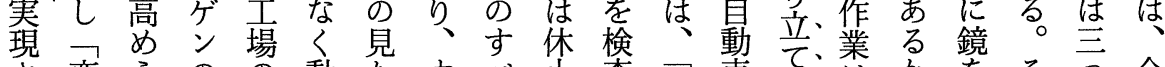

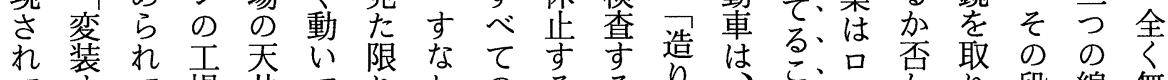

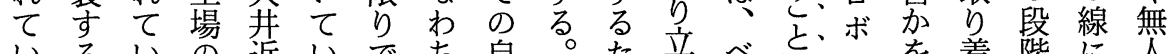
いるいの近いでち自。た立べと、ッを着階に線

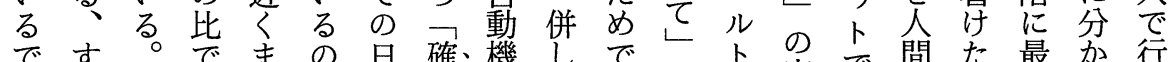

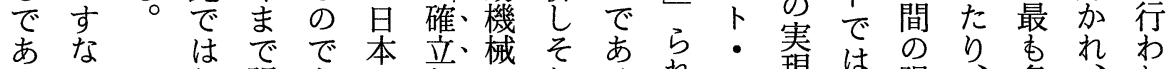
ろわな張あのし、にれるれる現岕眼、多、れ

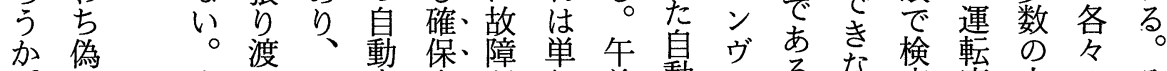

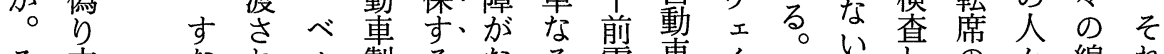
そ立なれル製るなる零車イな机な線れ のて わてト造こ、い休時がヤそこて計がはが 工省占

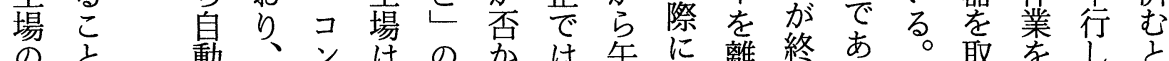

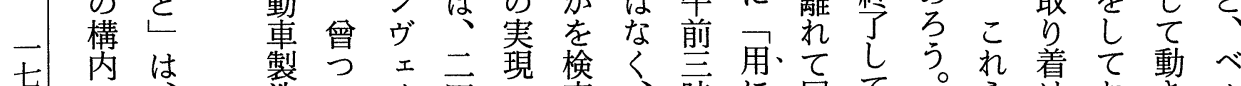

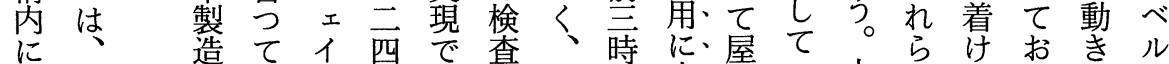

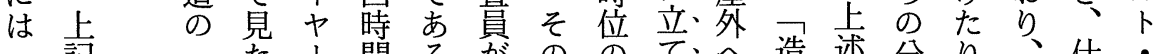

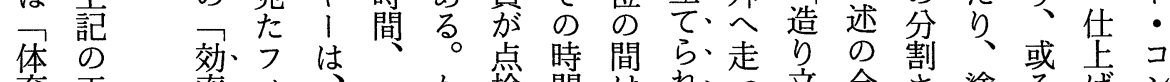

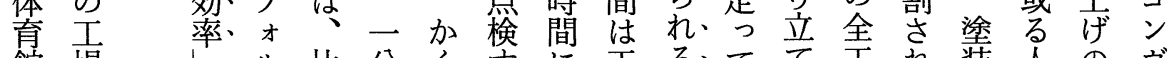

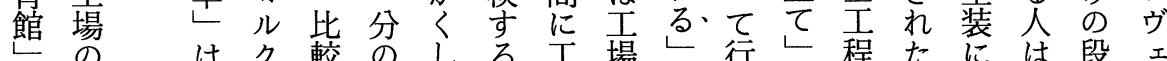

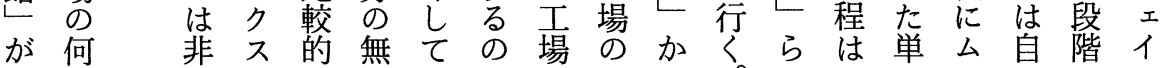


(2) で言にとあ人的あを合るの装ンれ施生フあ

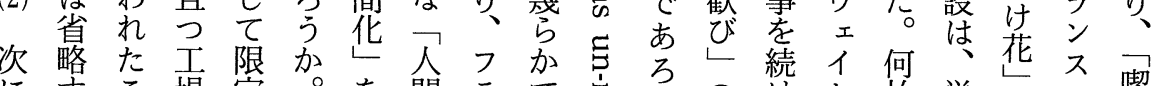

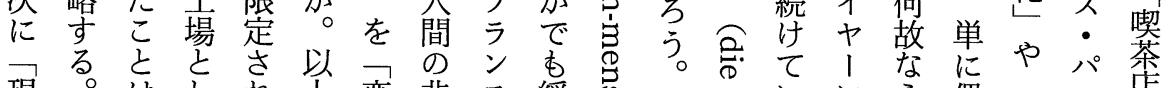

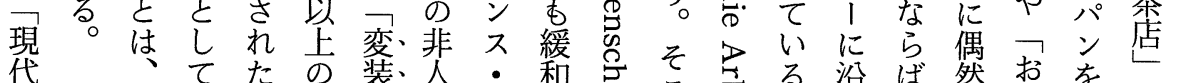

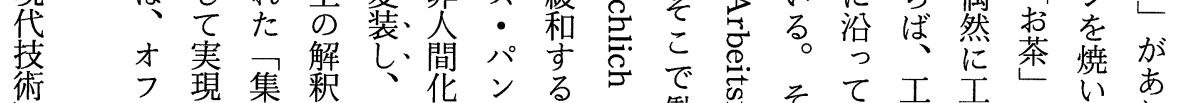

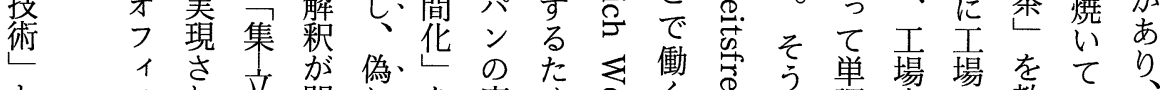

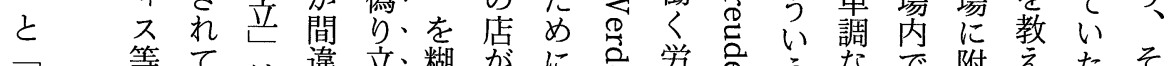

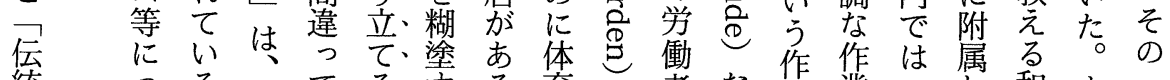

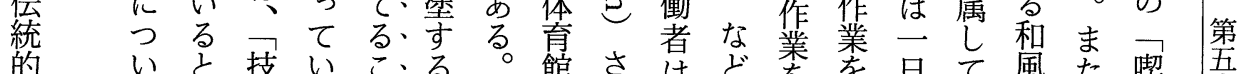

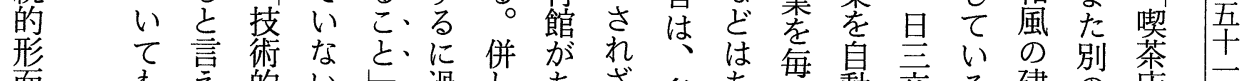

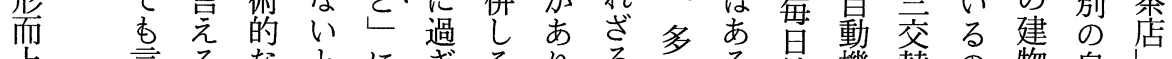

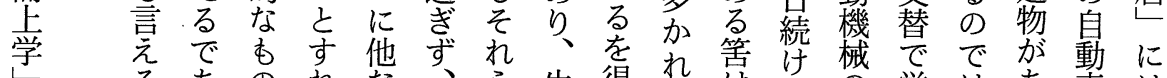

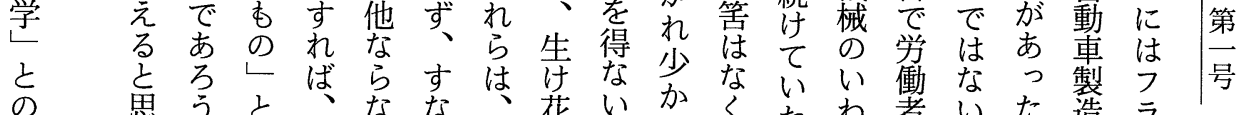

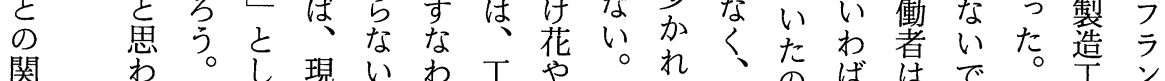

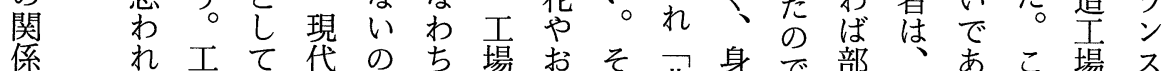

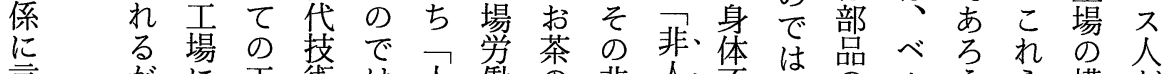

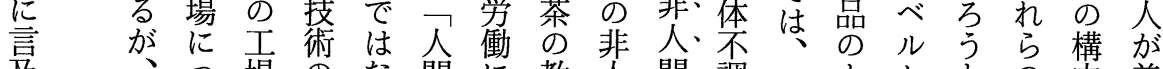
及こつ場のな間に教人間調っよ卜との内美

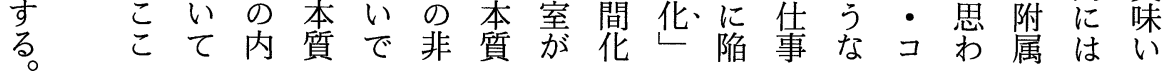

一象壮にとのミ於理导すと質引十のへに

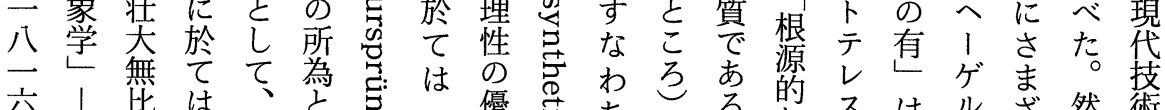

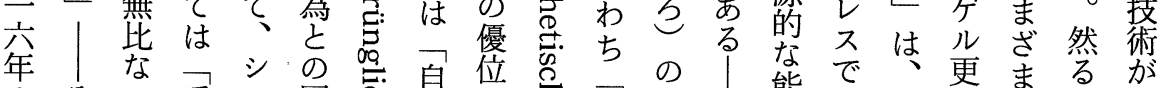

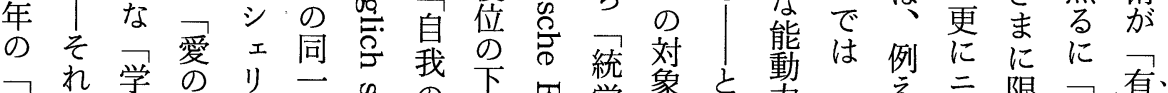

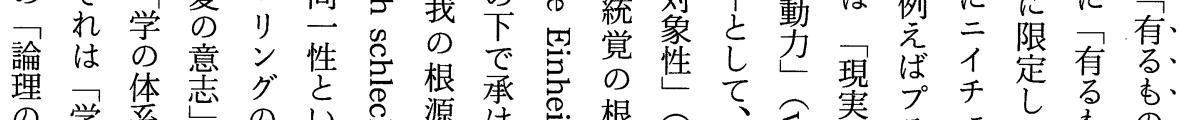
学学系思

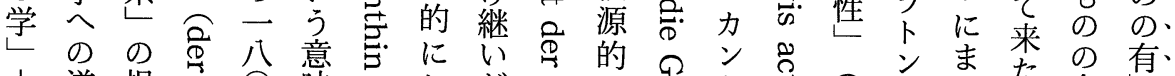

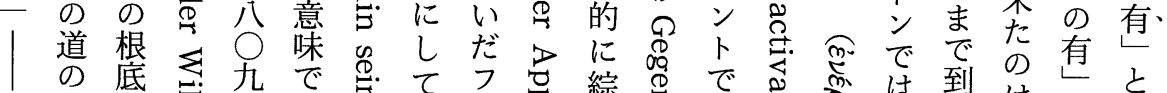
こ学を䇥年の吉 て

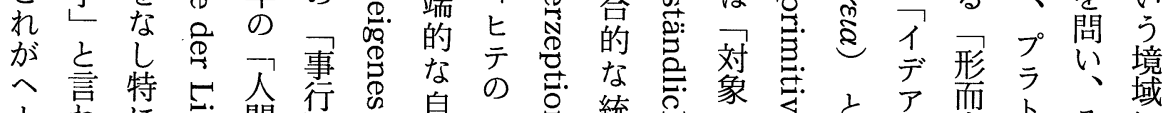

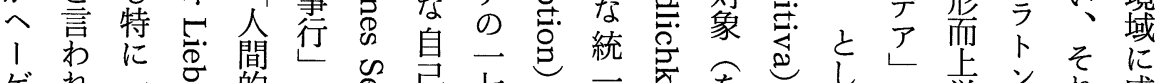

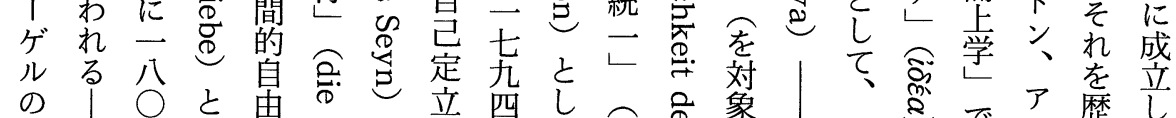

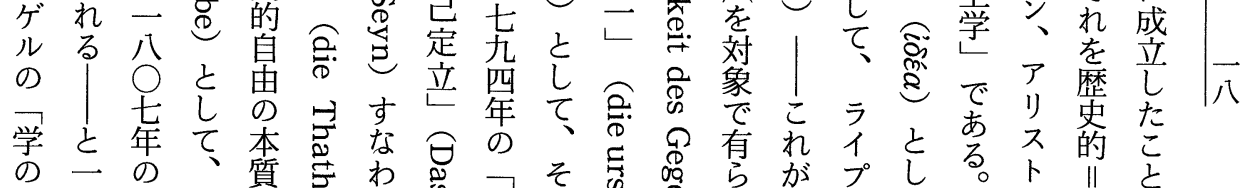

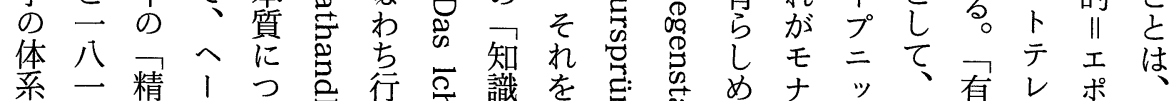

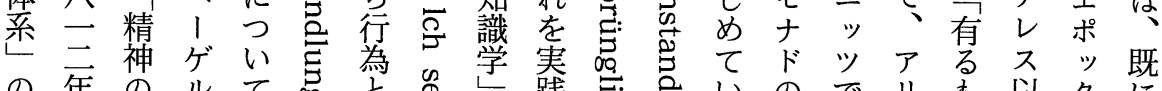

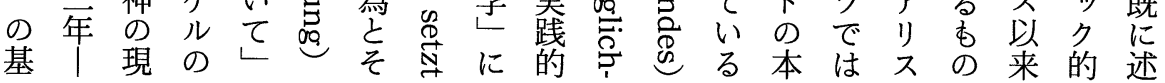




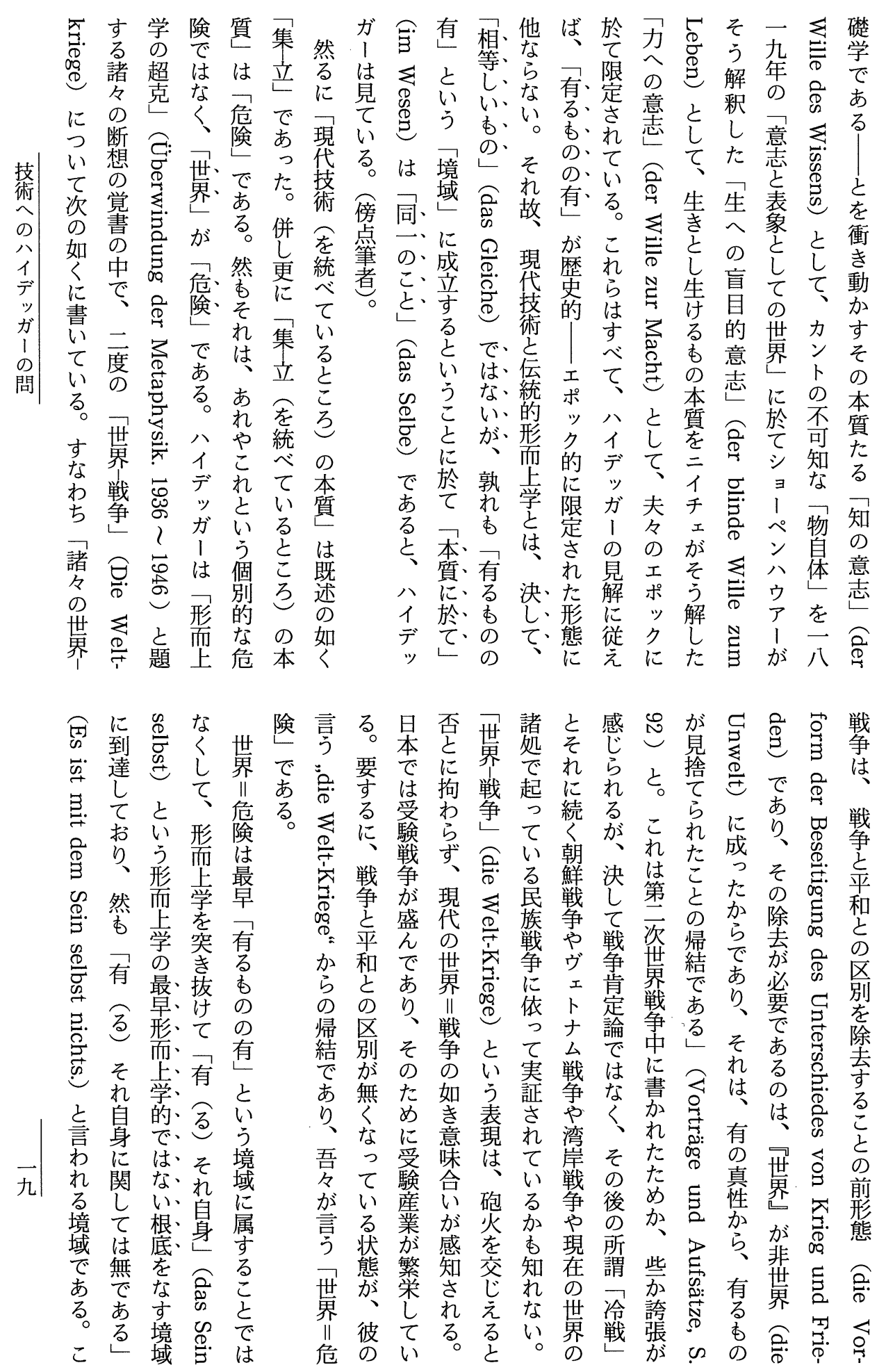


到却がの以併二無索な索八での四あ態恕れ

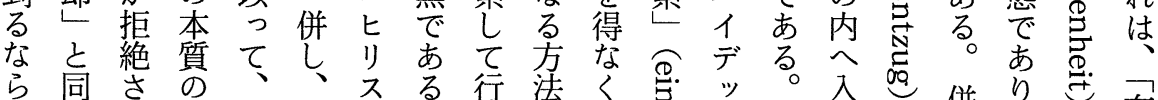

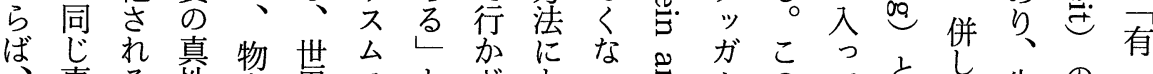

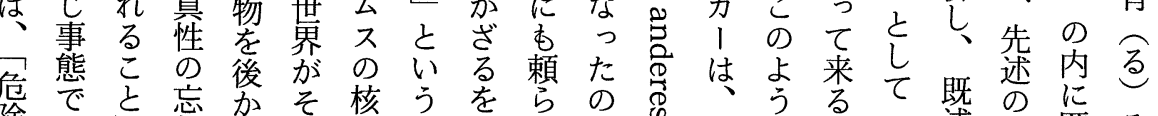
険あと却ら机事得ずでも形なこ述の匿そ

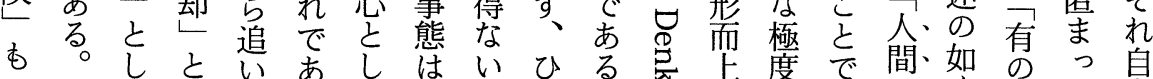

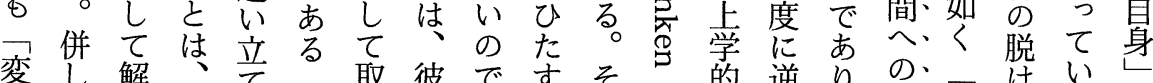

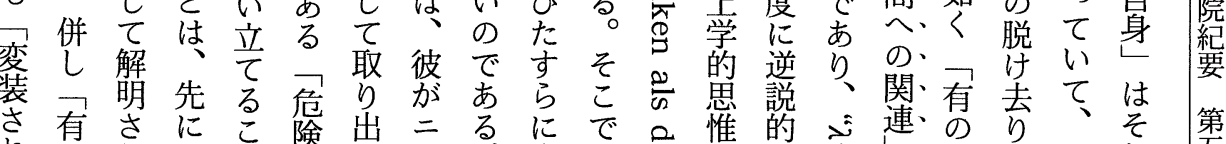

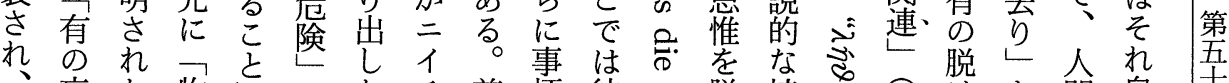

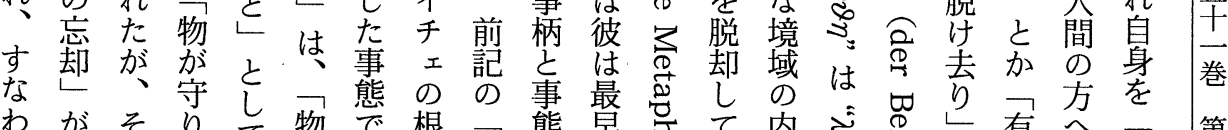

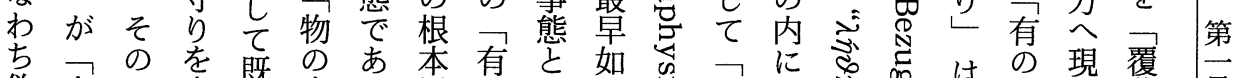

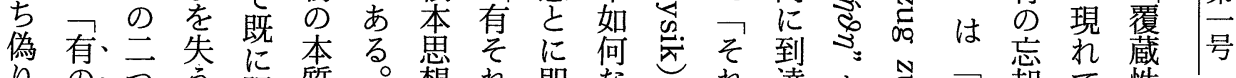

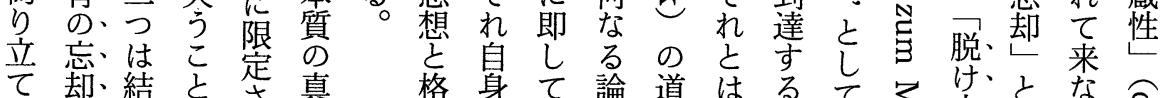

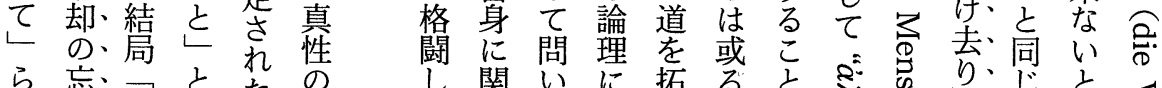

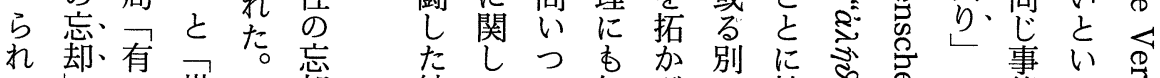

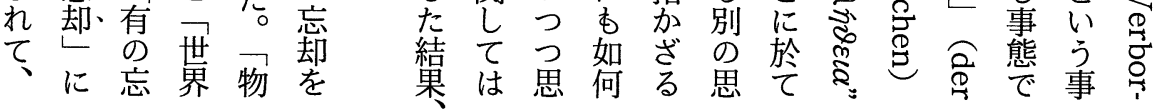

こ 有具 先振こ英有世

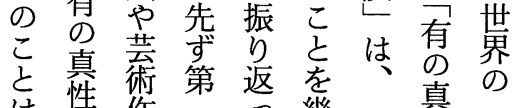

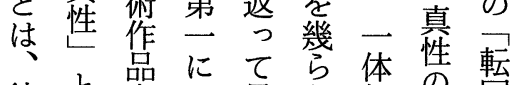
彼哭に見吕何の回 の言市物なで処莣去 思わ念念げれ考吾却吕 怔たてあは号以若

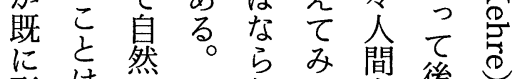
には然八なる型間後

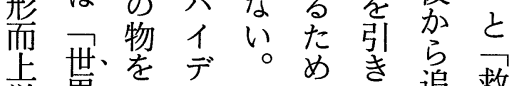
学界、ッき追救 的思物 ガ は ら

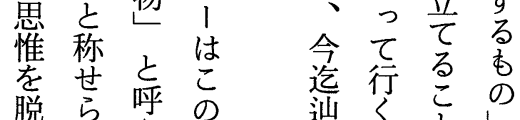

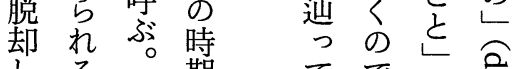

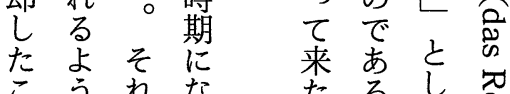
こう标な 示。時道 簢そ危呑
乙 总全救間う点間危.

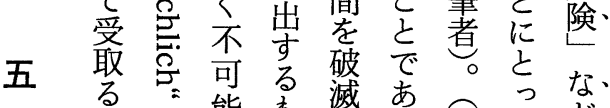
知な能市滅あるこで゙、

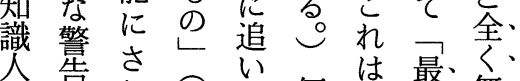
は老㤂总立何菄最、無、 ド単し师るな風険ささ

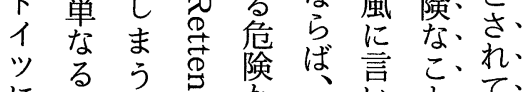

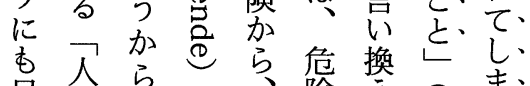
澘騷でが、険え

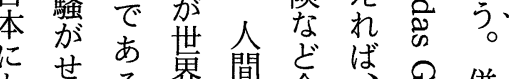
它屋る。界間全ばすの併

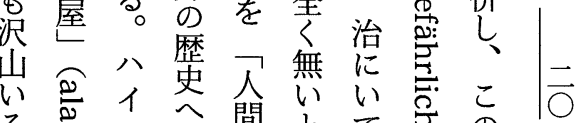
る

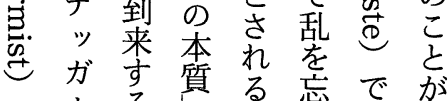
の れ こ 

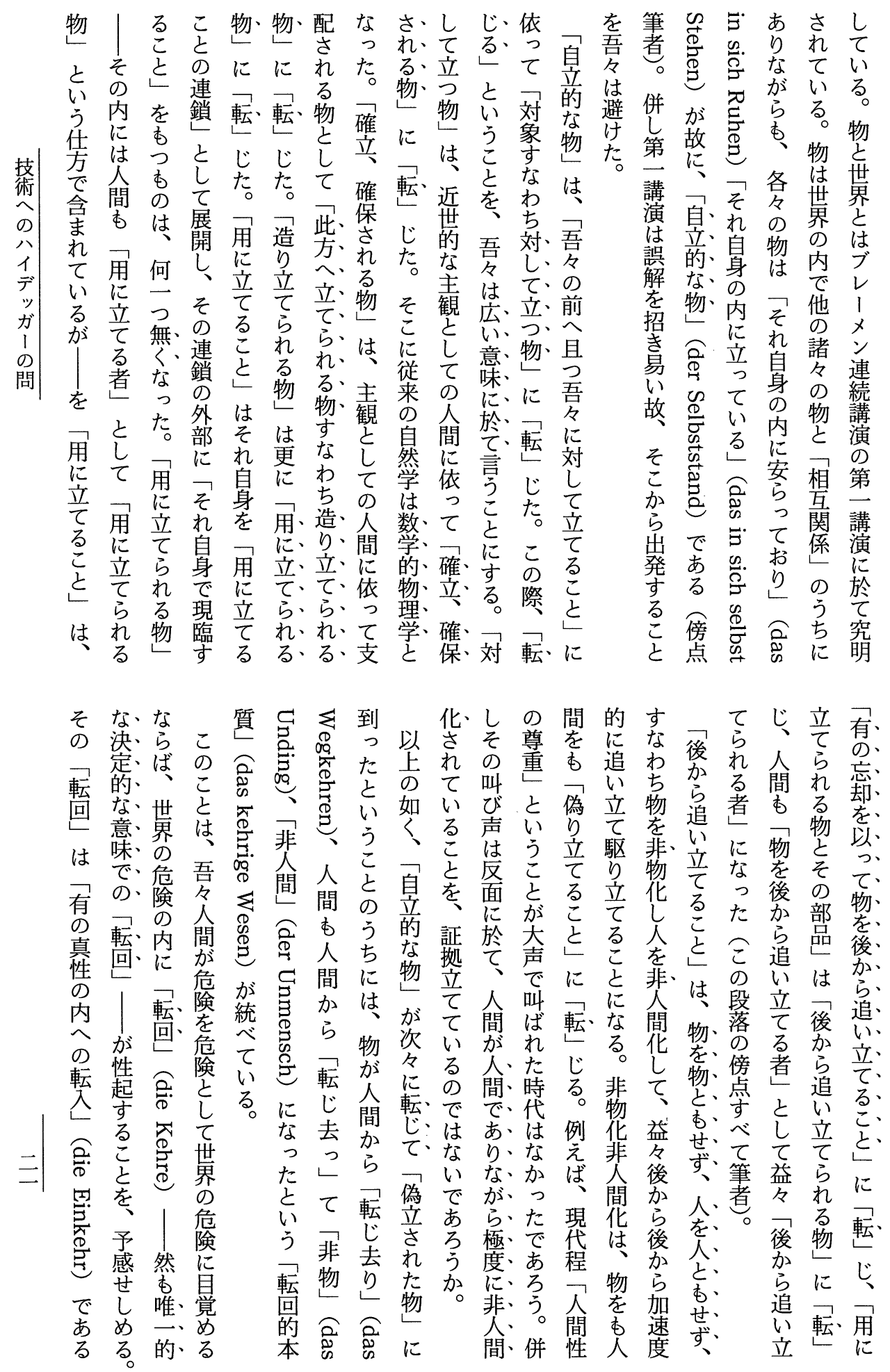


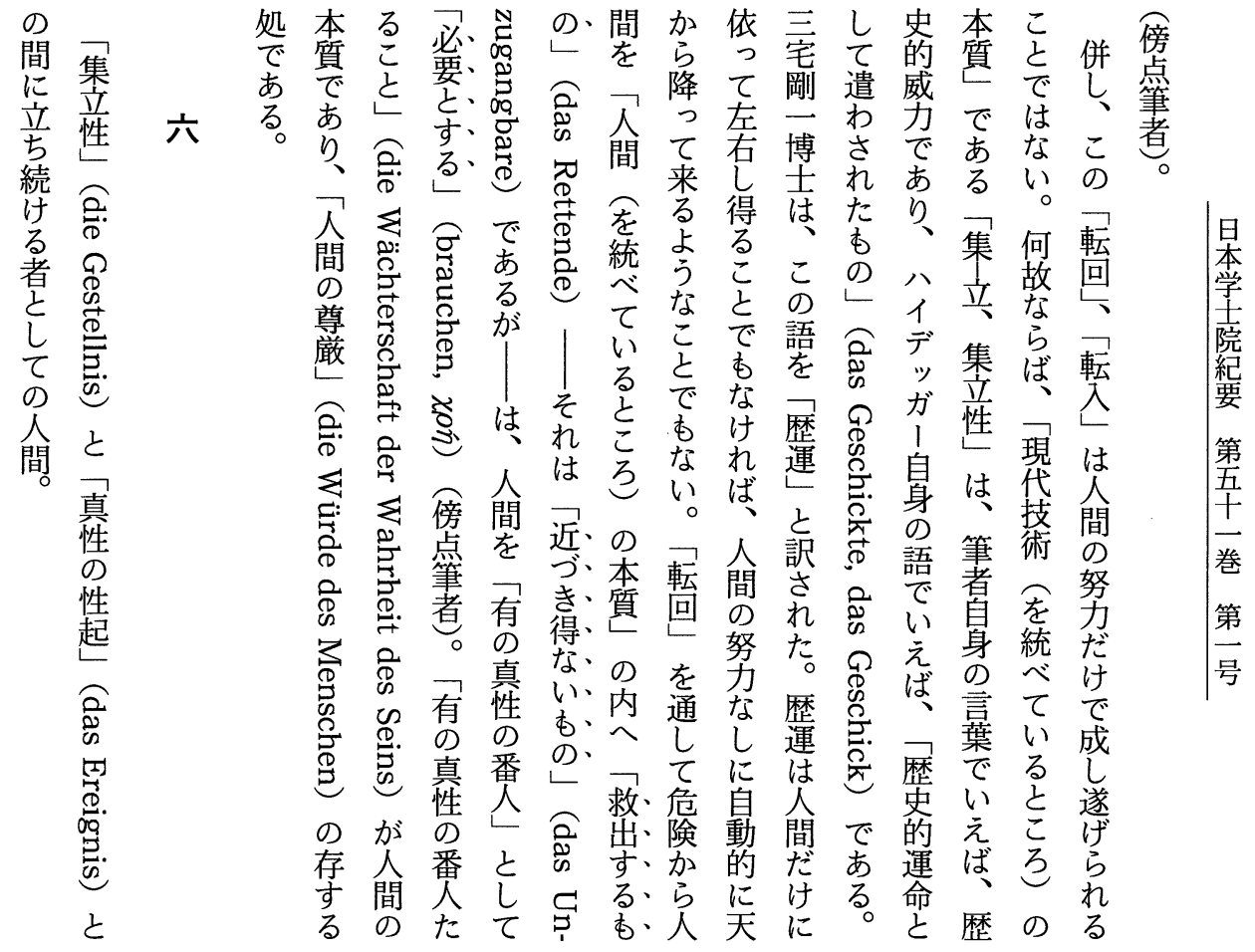

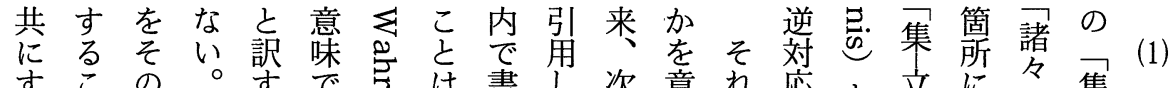
すこの 。专で空は書し次意れ応々立に名集

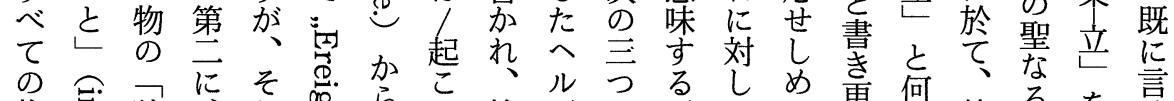

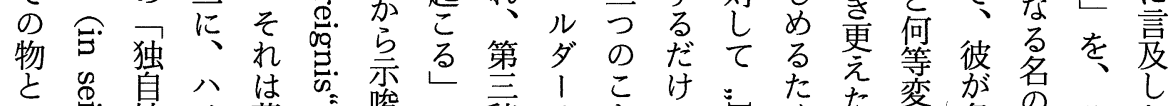

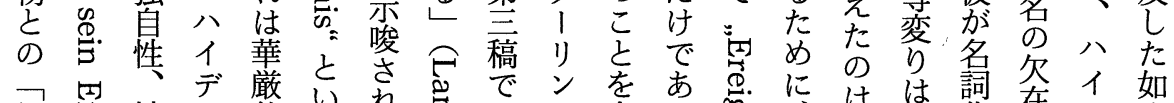

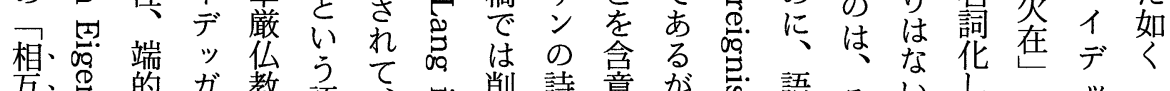

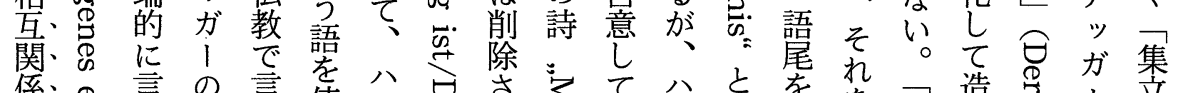

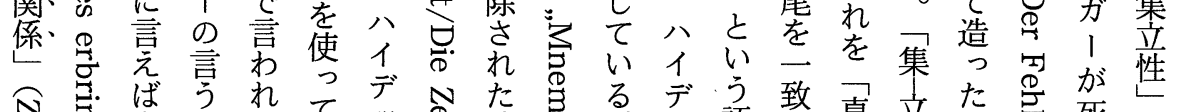

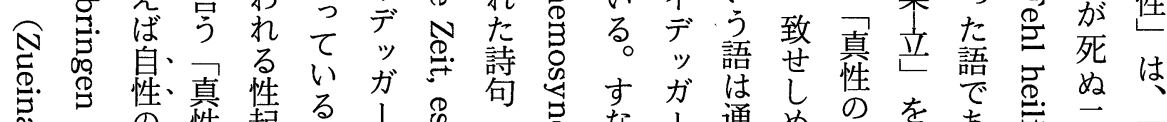
总吉 内性起 る

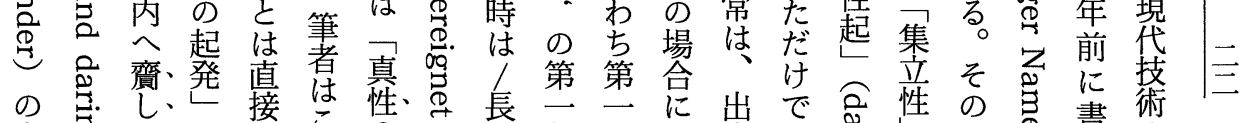

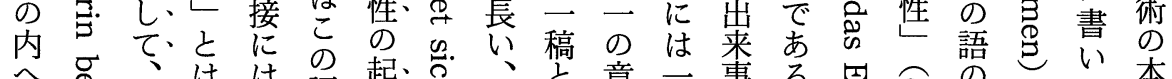

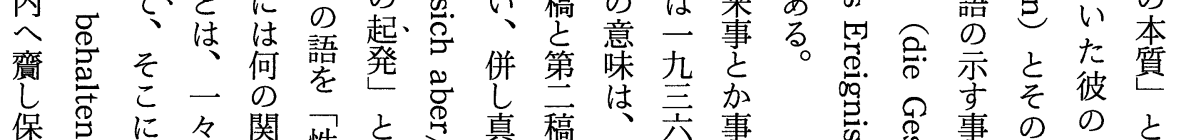

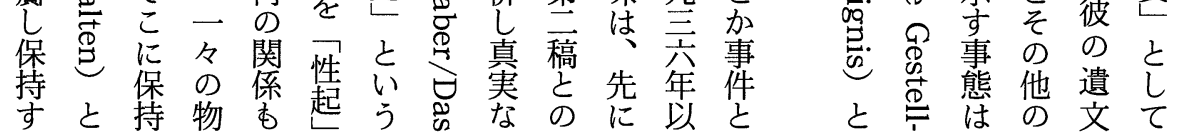




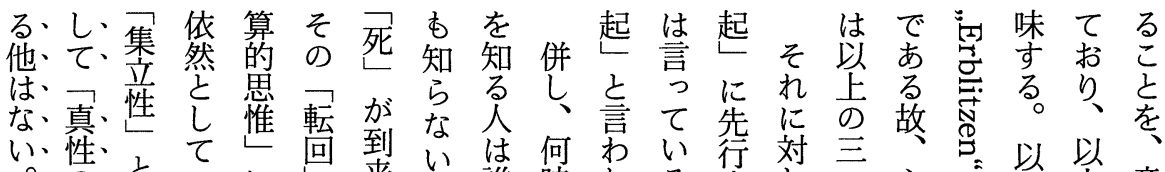

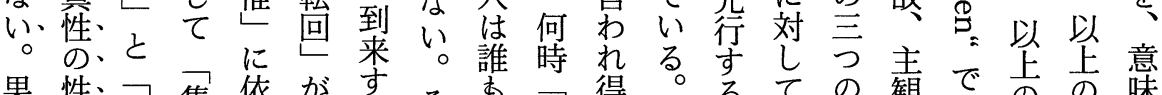

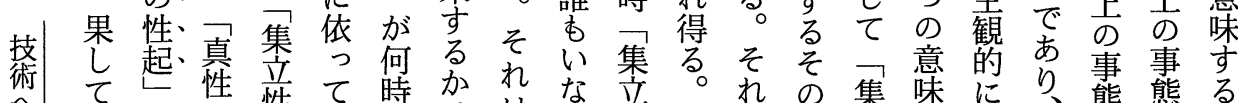

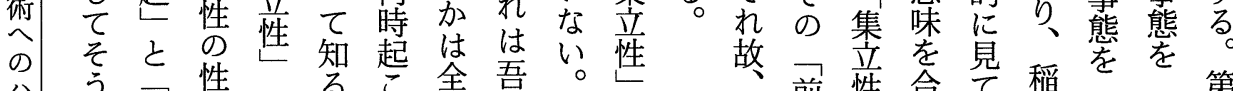

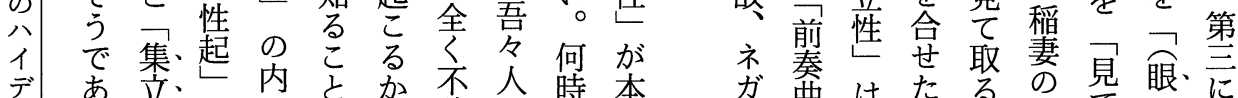

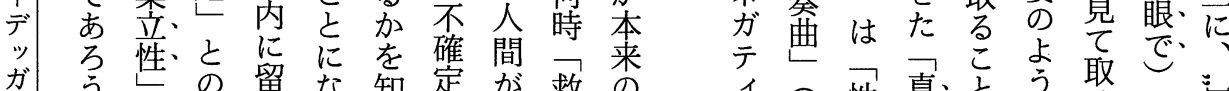

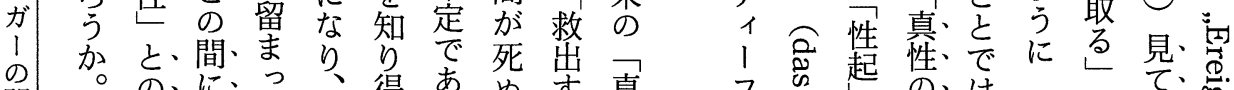

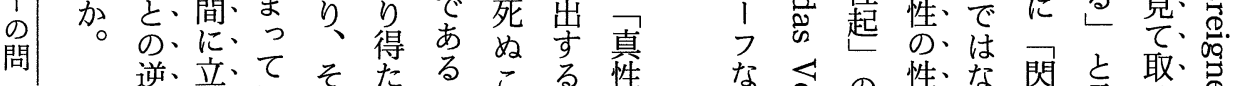

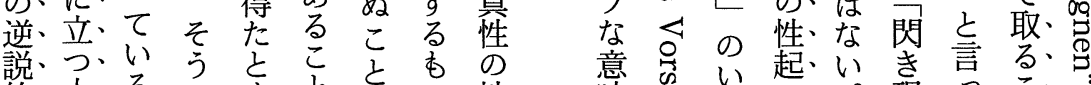

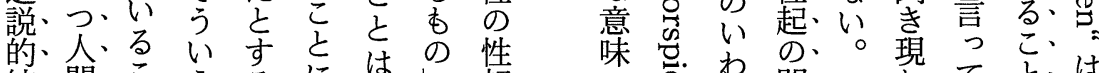

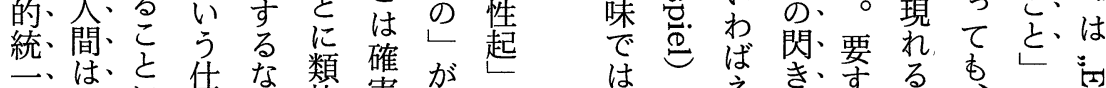

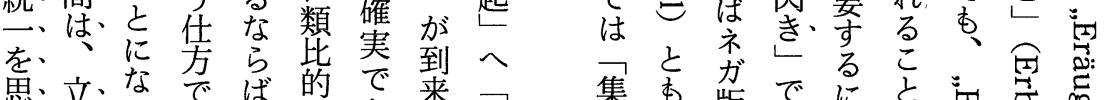

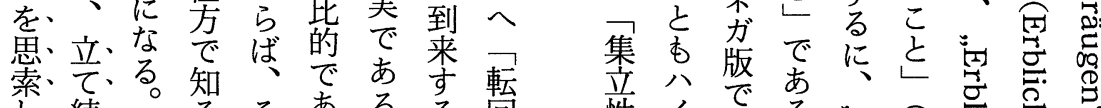

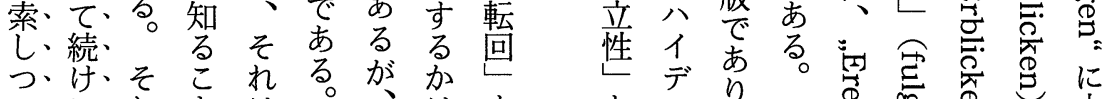
つ、に、れ

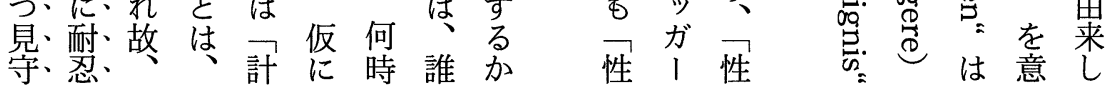

なそ言て術彼関る的でそて 次真凹きは真 ド ッ祭た終問技 凤

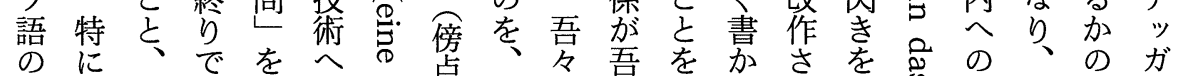

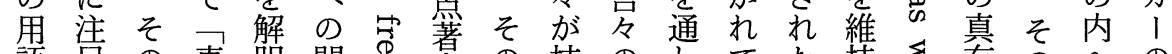
語自の真明問态著の技のしてた持芯有のへの のしこ性 す

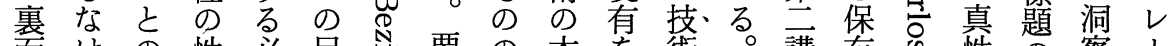
面けの性必目、苍要の本を術。講有吕性の察 1

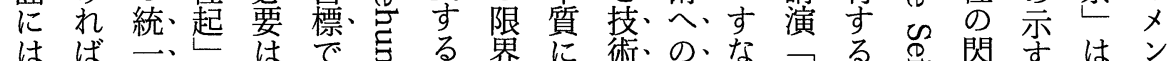

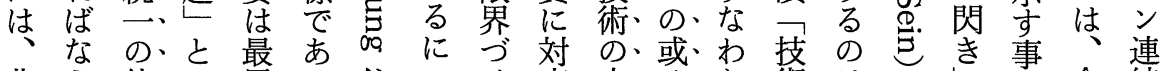

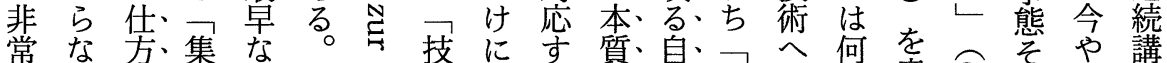

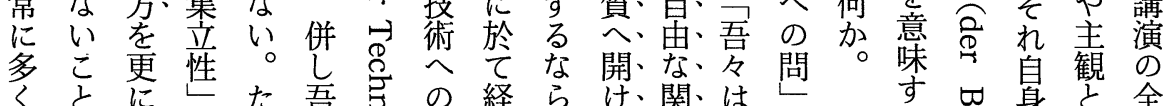

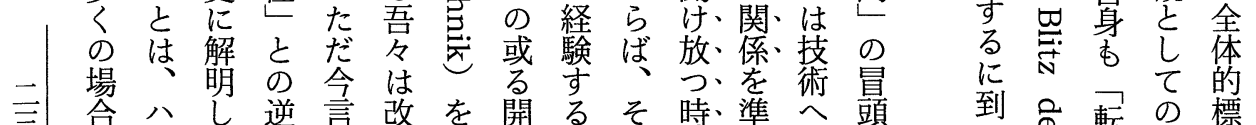

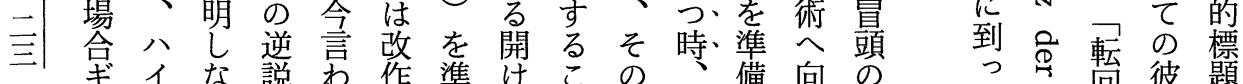

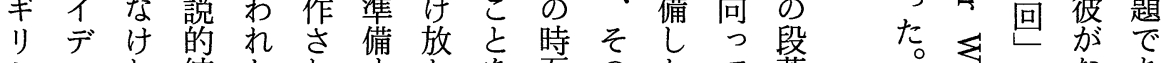

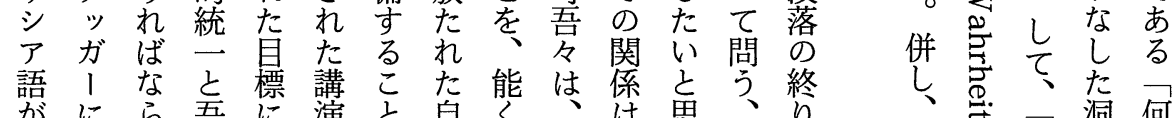

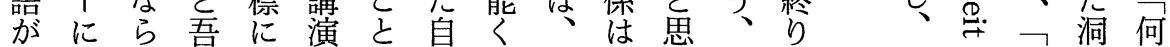

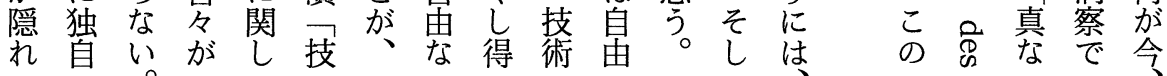




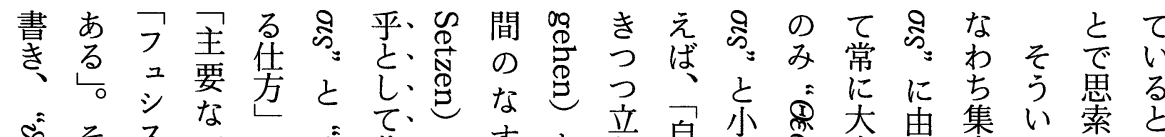

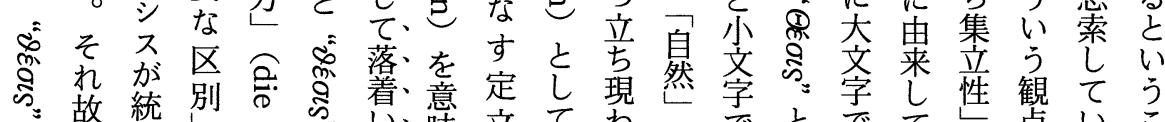

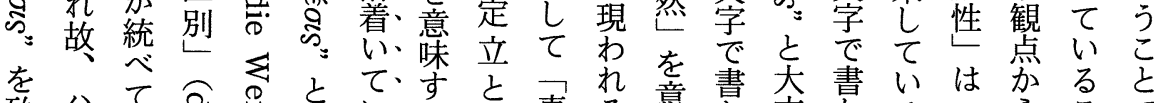

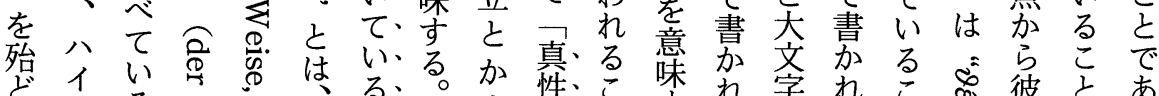

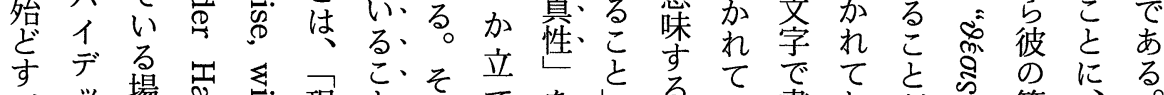

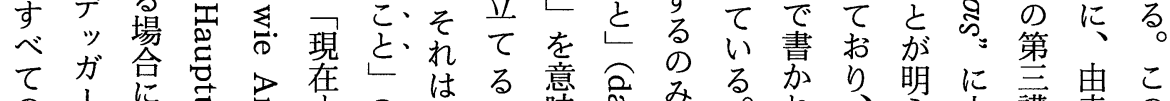

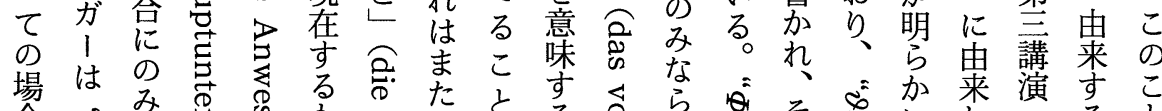

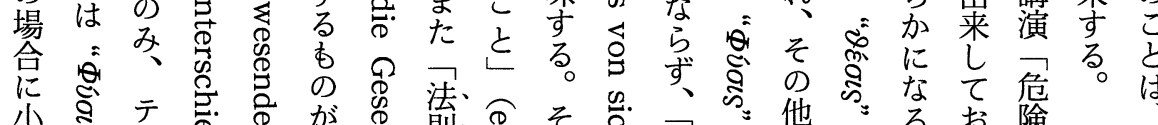

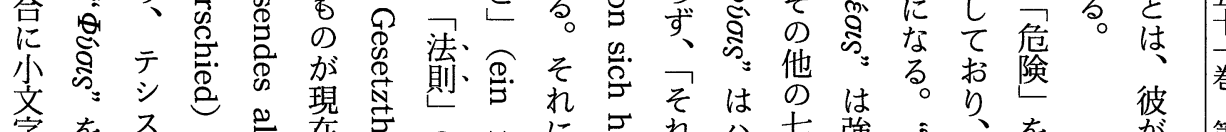

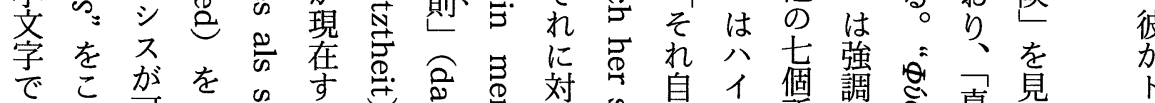

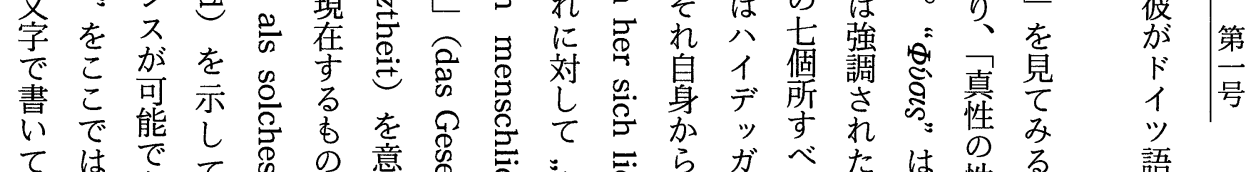

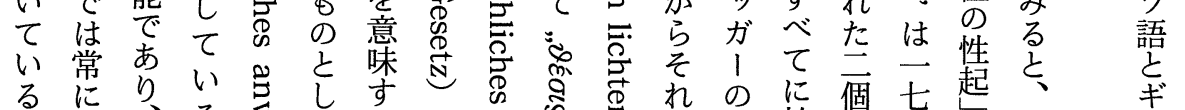

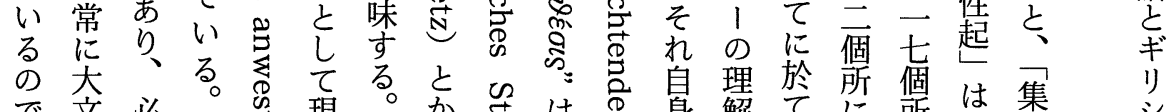

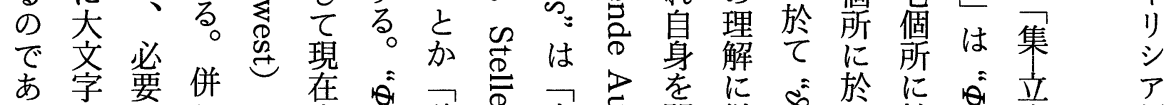

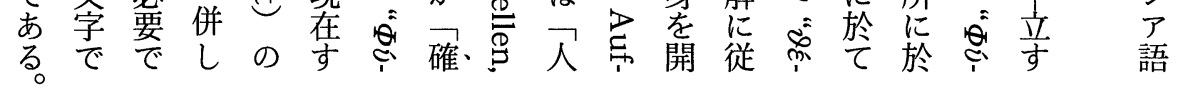

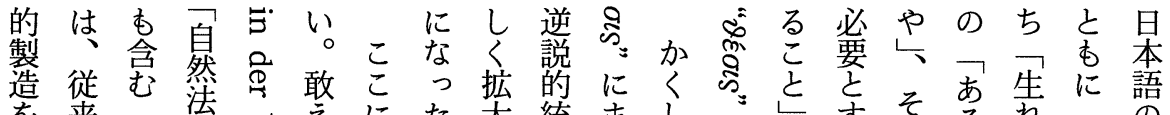

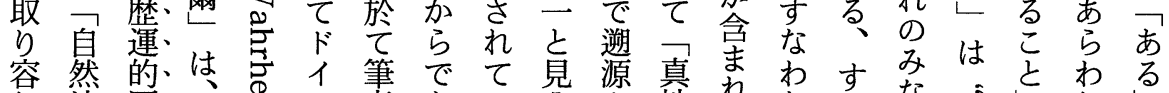

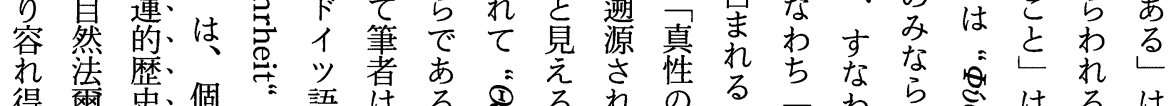

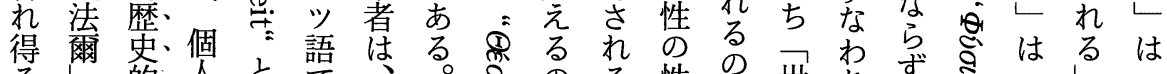

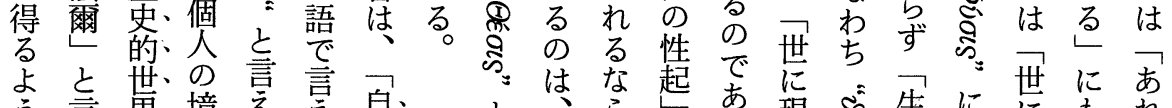

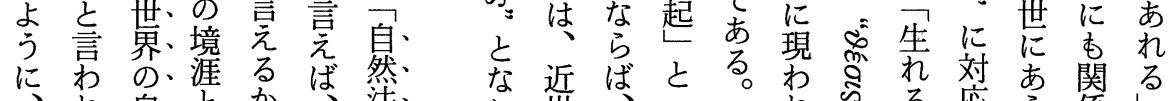

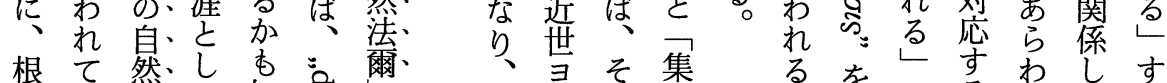

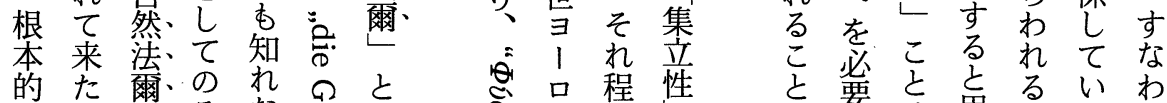

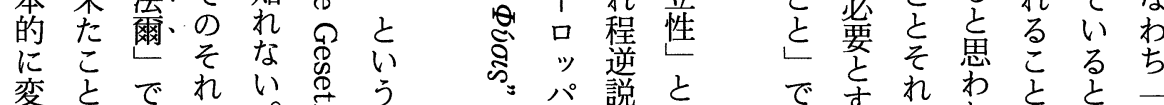

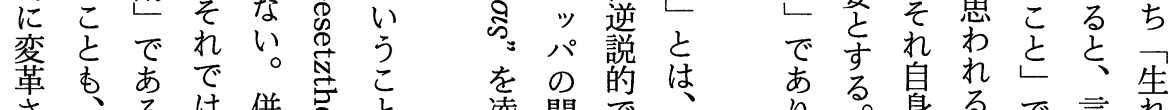

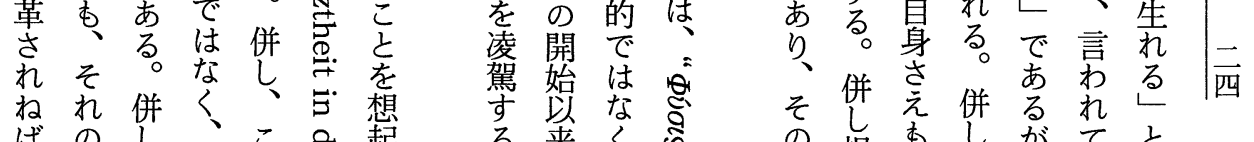

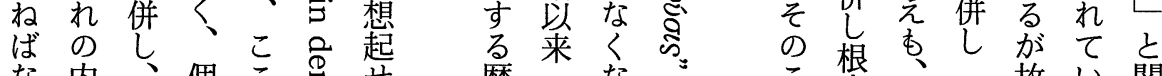

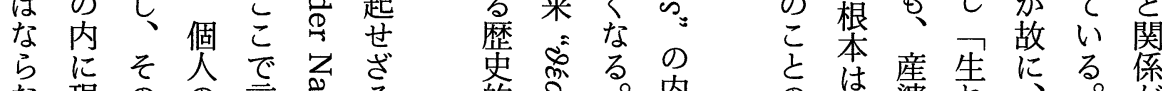

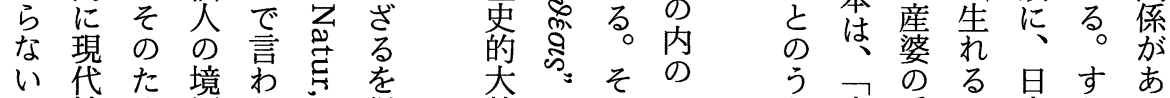

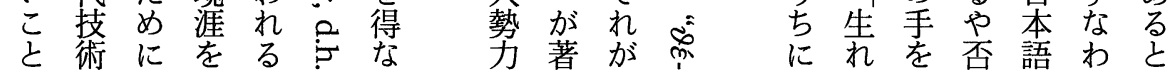



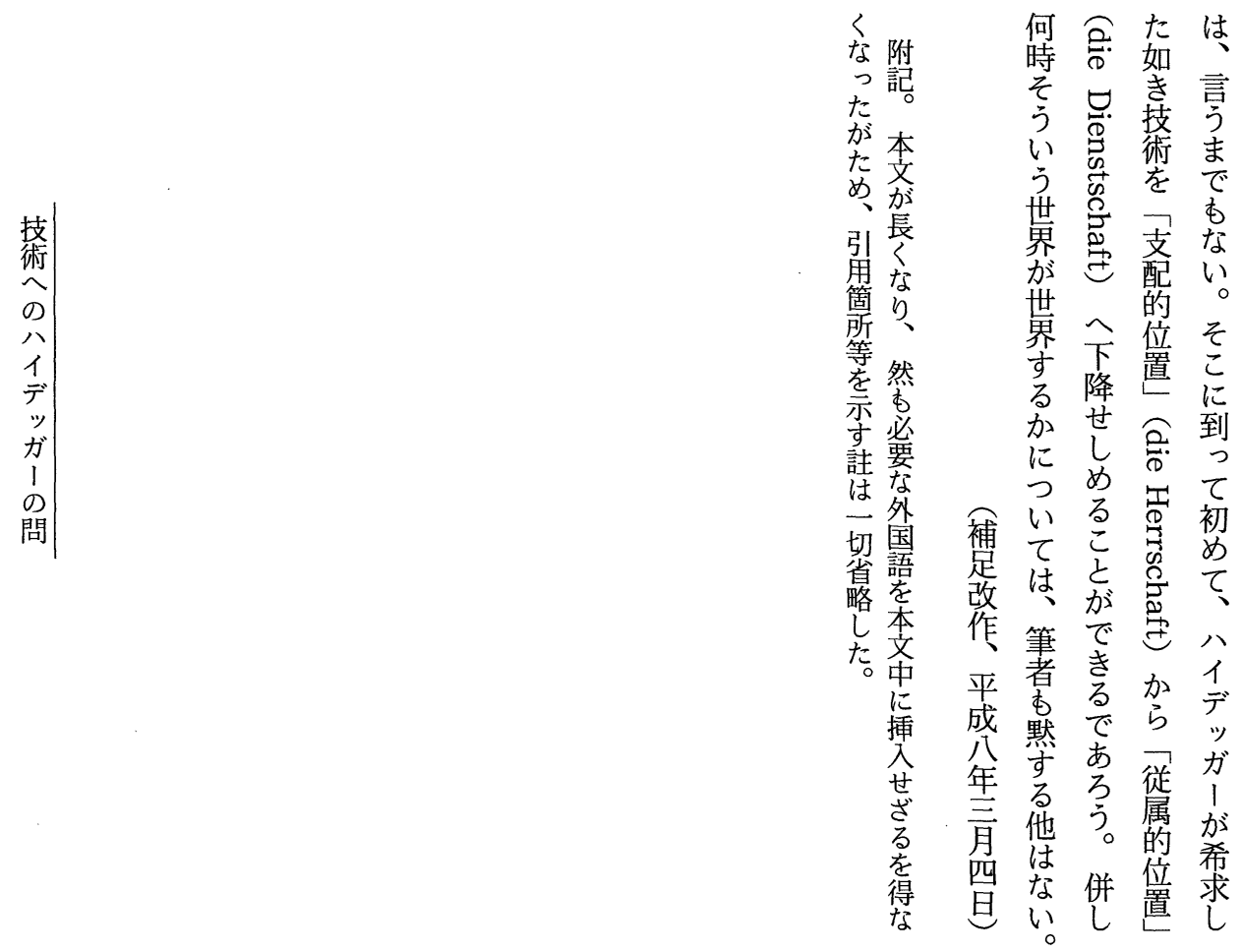

五 
Japaner an das "Jinen-hôni" ( 自然法爾) erinnern. Dieses bedeutet die Gesetztheit in der Natur bzw. in der Wahrheit, aber nicht im Sinne der Herzenslage des

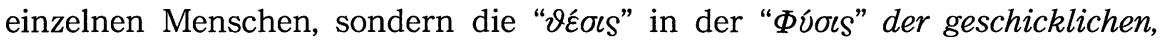
geschichtlichen Welt, in der erst die Technik von der „Herrschaft“ zur „Dienstschaft" herabgesetzt werden kann. 
mit dem Wort „Ereignis“ gebracht werden könnte.

„Ereignis“ nennt meines Erachtens die Einheit der folgenden drei Sachverhalte: a) jegliches Ding und jeden Menschen in sein „Eigenes erbringen und darin behalten“ und zugleich in das "Zueinander“. b) „Ereignis“ besagt die "Wesung der Wahrheit des Seins“, d. h. das Welten der eigentlichen, wahren Welt. c) „Ereignis“ zeigt das „Eräugen“, d. h. das Erblicken, d. h. das Erblitzen der obengenannten Sachverhalte. Das Wort „Ereignis“ im Sinne Heideggers stammt, wenn der Verfasser vermuten darf, vielleicht aus dem Gedicht Hölderlins „Mnemosyne“ her. Dieser dichtet: „Lang ist/Die Zeit, es ereignet sich aber/Das Wahre“. Obwohl dieser Vers sehr mehrdeutig ist, interpretiert der Verfasser im Zusammenhang mit dem heideggerschen Denken vom Wesen der Technik diesen Vers Hölderlins vielleicht folgendermaßen: Lang dauert das langweilende Zeitalter, jedoch ereignet sich jäh die Wahrheit.

Die Gestellnis ist, wie Heidegger selber sagt, „gleichsam das photographische Negative“ des Ereignisses, „das Vorspiel zum Ereignis“. Die Gestellnis, die in der gegenwärtigen Welt waltet, wird durch die Kehre zum Ereignis gewendet.

Die Bestimmung des Menschen, dessen Wesen und Würde, wie schon erwähnt, in der „Wächterschaft der Wahrheit des Seins“ besteht, liegt darin, daß er inmitten der uneigentlichen und der eigentlichen Welt ständig innestehen muß, kurz in der „Inständigkeit“.

\section{$\mathrm{V}$}

Das Schlußwort. In den Bremer Vorträgen schreibt Heidegger das grie-

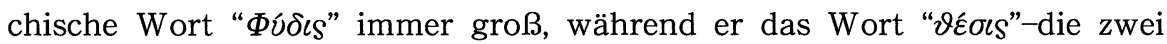

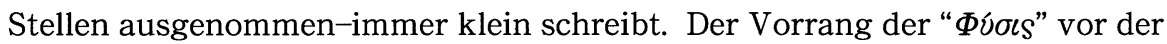

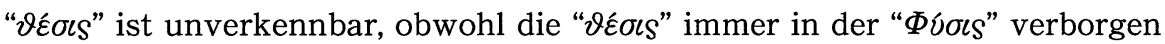

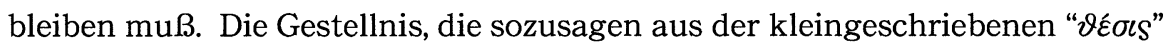
hergekommen ist, ist in der Neuzeit groß geworden. Dabei besagt die " $\vartheta \varepsilon ́ \sigma \iota "$ das Setzen und Stellen bzw. das Gesetz und die Gestellnis. Das immer gro-

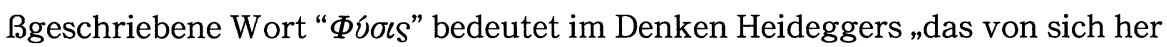
sich lichtende Aufgehen“, also die 'A $\lambda \hat{\eta} \theta \varepsilon \iota \alpha$, d. h. die Wahrheit im Sinne der ”

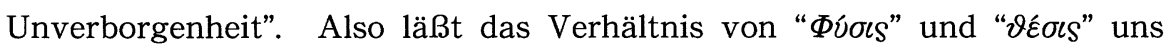


mathematischen Physik verwandeln. c) Das Sicherstellen kehrt sich zum "Herstellen“. Das Herstellen stellt das Ding als den Gegenstand her-d. h. in den Machtbereich des Menschen aus, und es erweitert zugleich dessen Machtbereich. Das Hergestellte ist das Gemächte. d) Das Herstellen kehrt sich von sich aus zum „Bestellen“. Das Bestellte und Bestellbare ist kein Gegenstand mehr, sondern der „Bestand“ bzw. das Bestandstück. Das Bestellen bildet die „Kette des Bestellens" aus. Hier hat der Verfasser zum Beispiel die Problematik des sogenannten Hirntodes und der Transplantation der inneren Organe herauszustellen versucht. e) Das Bestellen, in dem auch der Mensch als der „Besteller“ bestellt wird, kehrt sich zum „Nachstellen“ mit der Vergesssenheit der Wahrheit des Wesens des Dinges. Dieses Nachstellen, d. h. die "Gefahr“, ist das Wesen des Ge-Stells, d.h. das im Ge-Stell eigentlich Waltende. In diesem Nachstellen sind wir heute äußerst nachjagend und nachgejagt, hetzend und gehetzt. Das heißt: die Gedankenlosigkeit beherrscht unser tägliches Leben. Darin liegt: der Mensch muß wegen des Verlustes des Menschenwesens zusammen mit der „Verwahrlosung des Dinges“ und der „Verweigerung der Welt" unmenschlich werden. f) Allein die Gefahr verstellt sich selbst, so als ob es überhaupt keine Gefahr gäbe. Die so verstellte Gefahr ist dasselbe, was Heidegger in „Sein und Zeit“ zunächst den „Verfall“ und in der kleinen Schrift "Vom Wesen der Wahrheit" die "Irre“ genannt hat. Das Sichverstellen der Gefahr ist jedoch das "Gefährlichste“, weil das Verstellen der Gefahr als die Gefahrlosigkeit keinen Bereich mehr gewährt, in den das „Rettende“ gelangen kann. Dagegen, wenn die Gefahr als Gefahr anwest, dann ist schon das „Rettende“. Das ist die einzigartige „Kehre“ der ganzen Welt.

IV

Das Verhältnis der letztgenannten Gefahr und des Rettenden bleibt das Rätsel, anders gewendet, die endgültige Aporie, das „Unzugangbare“.

Heidegger hat zwei Jahre vor seinem Tode in seinem großartigen, dichterischen und denkerischen Aufsatz „Der Fehl heiliger Namen“ (1974) das Wort "Ge-Stell" einmal so geschrieben: „Gestellnis": beide Worte bedeuten dasselbe. Die Umschreibung kommt, wenn der Verfasser richtig vermutet, daher, daß das Wort "Ge-Stell“ in den scheinbar disharmonischen Einklang 
Heidegger sagt unter der Überschrift „Cézanne“ Folgendes: „Im Spätwerk des Malers ist die Zwiefalt/von Anwesendem und Anwesenheit einfältig/geworden, »realisiert« und verwunden zugleich,/verwandelt in eine geheimnisvolle Identität“.

III

In der Entsprechung zu den oben genannten 5 Bereichen der ontologischen Differenz, die Heideggers Denken immer tiefer bohrend erreicht hat, können wir die Bereiche der Technik folgendermaßen zuordnen: 1) In den Bereich des Seienden gehört „das Technische“. Das Technische sind die verschiedenen Maschinen, die Automaten, die Roboter, die Apparaturen, die Fabriken, die Atomkraftwerke, kurz, alle Produkte der Technik.

2) In den Bereich des Seins des Seienden gehört „die Technik,“ insbesondere die moderne Technik. Da die Metaphysik von Platon und Aristoteles bis zu Nietzsche jeweils epochal unterschiedlich das Sein des Seienden bestimmt hat, so sind die Metaphysik und die moderne Technik im Wesen das Selbe, obwohl sie gar nicht das Gleiche sind.

3) Im Bereich des Seins selbst waltet der „Nihilismus“ in dem Sinne „daß es mit dem Sein selbst nichts ist“. Zu diesem Bereich gehört noch die moderne Technik in ihrer gesteigerten Gestalt.

4) Der oben genannte Kernsatz, daß es mit dem Sein selbst nichts ist, zeigt schon den Entzug des Seins selbst, d. h. die Seinsvergessenheit. In diesem Bereich des Entzugs des Seins selbst gehört das "Wesen der modernen Technik“, d. h. das Ge-Stell. Das Ge-Stell als Nihilismus, wie sich später zeigen wird, ist die Versammlung des Stellens. a) Zuerst kommt das „Vorstellen“, d. h. das vor uns und zu uns und gegenüber uns Stellen, Das „Vorgestellte“ ist kein „noema als Korrelat der noesis“, d. h. kein dem Bewußtsein Immanentes, sondern der „Gegenstand“ wie z. B. ein Apfelbaum im Garten. b) Das „Vorstellen“ des

元 Gegenstandes kehrt sich von sich aus zum „Sicherstellen“ des Gegenstandes, wenn wir hier schon das Wort „Kehren“ im weiteren Sinne gebrauchen könnten. Aus dem Sicherstellen oder Feststellen her kommt die Wahrheit der neuzeitlichen Wissenschaft und Metaphysik als die „certitudo“, d. h. die "Gewißheit des Vorstellens“ zum Vorschein. Die alte Physik mußte sich zur 
Was die heideggerschen Bremer Vorträge anbelangt, hat der Verfassesr die Interpretation nicht mit dem ersten Vortrag „Das Ding“ begonnen, sondern mit dem zweiten Vortrag „Das Ge-Stell“. Beginnt man nämlich mit dem ersten Vortrag, so sind viele Mißdeutungen, etwa als bloße Utopie, als altmodischer Provinzialismus und so weiter fast unvermeidlich.

Die „ontologische Differenz“, die Heidegger noch nicht eigens in seinem ersten Hauptwerke „Sein und Zeit“ (1927), sondern erst im der unmittelbar daran schließenden Marburger Vorlesung „Die Grundprobleme der Phänomenologie" (1927, Sommersemester) mitgeteilt hat, besteht meines Erachtens im Unterschied der folgenden Bereiche: 1) Das „Seiende“, 2) Das „Sein des Seienden“ im Sinne des Grundes des Seienden. Mit Sein des Seienden oder Seiendheit übersetzt Heidegger die aristotelische "ớoía". Da das Sein des Seienden vom Seienden her als dessen Grund verstanden ist, bleibt es „dem Seienden noch botmäßig“. 3) So wird das „Sein als solches“, d. h. das „Sein selbst“ zur Frage. Anstatt des "Seins selbst“ kommt in der traditionellen

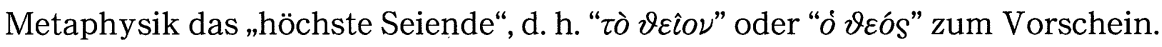
Dieser Gott ist der „Gott der Philosophen“, der vom metaphysischen Denken gestellt wird, damit dieses Denken sich selbst zum Abschluß bringen kann. Mit diesem Gott bleibt jedoch das Sein selbst verdeckt oder vielmehr vergessen und verborgen. Hier herrscht der „Entzug des Seins selbst“ vom Menschen. Also können wir das Sein selbst im Entzug oder im Ausbleiben als die Verborgenheit $(\lambda \dot{\eta} \theta \eta)$ des Seins, d. h. als die „Unwahrheit des Seins“ verstehen. Dies ist das "Geheimnis" im einen, einzigsten Sinne. 4) Wenn wir aber vom Entzug des Seins als solchem die Erfahrung machen können, so kommt der Entzug des Seins als solcher in „den Bezug des Seins zum Menschen“. Das ist die " $\alpha-\lambda \hat{\eta} \vartheta \varepsilon \iota \alpha$ ". Also ist die Unwahrheit des Seins selbst zugleich in einem wesentlichen Paradox die Wahrheit des Seins selbst, die früher in "Sein und Zeit“ der „Sinn von Sein“, dann die „Wahrheit des Seins“ genannt wurde. 5) Aber die Wahrheit des Seins qua Unwahrheit des Seins muß als das Sein der Wahrheit ins Ding (res) als Ding „realisiert" werden. Eine solche "réalisation“ sieht Heidegger zum Beispiel in den späten Werken des Malers Cézanne „La Montagne Sainte-Victoire“ (1904-1906) und „Le Jardinier Vallier“ (1906). 
durch die nachkommende Metaphysik bis hin zu Leibniz als die "Substanz“ und deren „Substanzialität“ übersetzt und zur Leitfrage der Metaphysik gemacht, obwohl die „individuelle Substanz“, d. h. die „Monade“, insbesondere der „esprit“, zu dem die "monas“ durch das Wissen von sich selbst sowohl als auch von Gott aufgestiegen hat, hat in Wahrheit schon den Charakter des Subjektes angenommen.

Nach dem Tode Leibnizens (1716) hat sich die Substanz zum Subjekt gewandelt. Kant (1724-1804) macht in seiner vorkritischen Periode zwar immer noch Gebrauch vom Begriff der Substanz. Aber dann kommt, soweit mir bekannt ist, erstmals in seiner Schrift „Träume eines Geistessehers“ (1766) und insbesondere in seiner Habilitationsschrift „De Mundi sensibilis atque intelligibilis Forma et Principiis“ (1770) der Begriff des Subjektes und des Objektes ganz deutlich zum Vorschein. In diesem Zeitraum tritt, nach den Forschungen meines langjährigen Bekannten Herrn Wolfgang Brokmeier, und zwar innerhalb der protestantischen, vom deutschen Cartesianismus stark geprägten Theologie der Begriff des „Subjekts“ mehr und mehr zutage. Es wird nunmehr zu einem Hauptproblem der Metaphysik, die Subjektivität des Subjektes im Verhältnis zum Objekt zu bestimmen.

Dagegen erblickte Heidegger, der sich nach seiner Habilitationsschrift „Die Kategorien- und Bedeutungslehre des Duns Scotus“ (1916) intensiv mit der phänomenologischen Interpretation von Aristoteles beschäftigt hat, blitz-

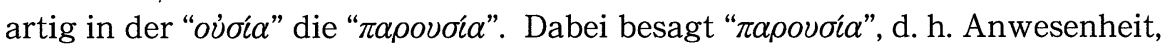
d. h. Präsenz, keine bloße Präsenz, sondern auch die Präsenz der Absenz. Die Präsenz der Absenz ist dieselbe wie die Grunderfahrung der Seinsvergessenheit, aus der her "Sein und Zeit“ gedacht ist. So kann man sagen, daß Heidegger, solange man sein eigenes Denken noch auf dasjenige des Aristoteles bezieht, seine genuine Frage nach dem Sinn von Sein nicht mehr als die Frage nach der mannigfachen Bedeutung des Seienden in der Relation zur "ovंøía", sondern

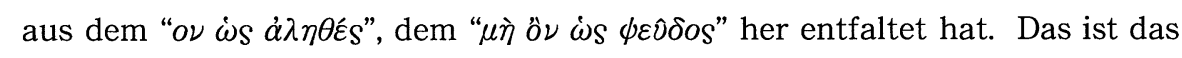
ganz entscheidende Ereignis in der gesamten Geschichte der abendländischeuropäischen Metaphysik. 


\title{
Heideggers Frage nach der Technik
}

\author{
IN SILENTIUM MAGISTRI TORATARÔ SHIMOMURA
}

Kôichi Tsujimura, M. J. A.

\section{Zusammenfassung}

Im vorliegenden Referat hat der Verfasser den Versuch gewagt, erstens den Wesensunterschied des heideggerschen fragenden Denkens von der

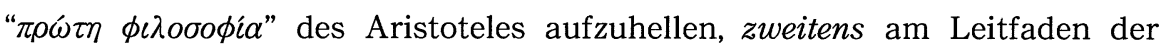
Bremer Vorträge (Gesamtausgabe Bd. 79, 1994) und seiner anderen Schriften die durch sein bohrendes Denken erreichten und immer tiefer sich öffnenden Bereiche der sogenannten „ontologischen Differenz“ zu erörtern, drittens in der Entsprechung zu diesen Bereichen dem Tiefgang des „kehrigen Wesens“ von „Vorstellen“, „Sicherstellen“, „Herstellen“, „Bestellen“, „Nachstellen“, bis hin zum „Verstellen“ nachzugehen, viertens das paradoxe Verhältnis der Wesung der „Gefahr als Gefahr“ und der Ankunft „des Rettenden“, d. h. das Verhältnis von "Gestellnis“ und „Ereignis“ sowie das Wesen und die Würde des Menschen als „Wächterschaft der Wahrheit des Seins“ sich anzueignen, und schließlich fünftens das zu erläutern, was mir das verborgene Ziel in Heideggers Besinnung auf den „Einblick in das was ist“ zu sein scheint, und zwar in Rücksicht

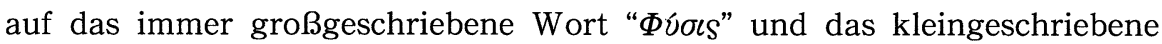
Wort " $\vartheta \hat{\varepsilon} \sigma \iota \varsigma$ " als den Einklang der großen Natur, d. h. der großen Wahrheit mit der darin umschlossenen, gewahrten Gesetztheit (japanisch: Jinenhōni) der geschicklichen, geschichtlichen Welt.

\section{I}

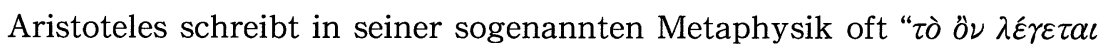
$\pi 0 \lambda \lambda \alpha \chi \omega \hat{s}$ ". In dieser fragwürdigen Situation versucht er, die Grundbedeutung des mannigfach erscheinenden Seienden in der Relation zur "ov̉oía"

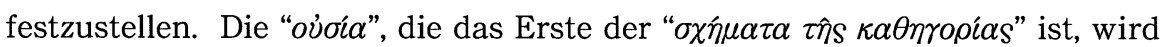

